\title{
Infrastructure and Growth in South Africa: Direct and Indirect Productivity Impacts of 19 Infrastructure Measures*
}

\author{
Johannes W. Fedderke ${ }^{\dagger}$ and Željko Bogetićs
}

\begin{abstract}
Empirical explorations of the growth and productivity impacts of infrastructure have been characterized by ambiguous (countervailing signs) results with little robustness. A number of explanations of the contradictory findings have been proposed. These range from the crowd-out of private by public sector investment, non-linearities generating the possibility of infrastructure overprovision, simultaneity between infrastructure provision and growth, and the possibility of multiple (hence indirect) channels of influence between infrastructure and productivity improvements. This paper explores these possibilities utilizing panel data for South Africa over the 1970-2000 period, and a range of 19 infrastructure measures. Utilizing a number of alternative measures of productivity, the prevalence of ambiguous (countervailing signs) results, with little systematic pattern is also shown to hold for our data set in estimations that include the infrastructure measures in simple growth frameworks. We demonstrate that controlling for potential endogeneity of infrastructure in estimation robustly eliminates virtually all evidence of ambiguous impacts of infrastructure, due for example to possible overinvestment in infrastructure. Indeed, controlling for the possibility of endogeneity in the infrastructure measures renders the impact of infrastructure capital not only positive, but of economically meaningful magnitudes. These findings are invariant between the direct impact of infrastructure on labor productivity, and the indirect impact of infrastructure on total factor productivity.
\end{abstract}

Keywords: growth, productivity, infrastructure, Africa, South Africa JEL: O40, O14, O49, O55

World Bank Policy Research Working Paper 3989, August 2006

The Policy Research Working Paper Series disseminates the findings of work in progress to encourage the exchange of ideas about development issues. An objective of the series is to get the findings out quickly, even if the presentations are less than fully polished. The papers carry the names of the authors and should be cited accordingly. The findings, interpretations, and conclusions expressed in this paper are entirely those of the authors. They do not necessarily represent the view of the World Bank, its Executive Directors, or the countries they represent. Policy Research Working Papers are available online at http://econ.worldbank.org.

*We wish to acknowledge the research assistantship support of Andrew Hill in the preparation and processing of the various data sets used for this paper. We also wish to acknowledge helpful discussions with Anton Eberhard, Mark Howels, Luis Guasch, David Canning and Ioannis Kessides. An earlier version of this paper was presented at the workshop on Infrastructure and Growth of Economic Research Southern Africa, May 29-31, 2005, Cape Town, South Africa.

$†$ School of Economics, University of Cape Town, Private Bag, Rondebosch, 7701, Cape Town, South Africa, jfedderk@commerce.uct.ac.za

§World Bank, 1818 H Street N.W., Washington D.C., 20433 U.S., zbogetic@worldbank.org 


\section{Introduction}

Infrastructure investments have been proposed in the development literature as an influential factor of economic growth, working through at least two of the three classic drivers of economic growth: directly via capital accumulation and indirectly via total factor productivity gains. Infrastructure investments are hypothesized to facilitate private investments by lowering production costs and opening new markets, thereby creating new production, trade and profit opportunities. Roads reduce transport costs and ports reduce transaction and trade costs. Both can be deemed to expose local firms to the innovative pressures of international competition.

Public capital can be readily incorporated in an endogenous growth framework, demonstrating expectations of a positive pay-off from investment in infrastructure, ${ }^{1}$ while a separate literature examines the question of which funding structure for public investment is optimal for growth purposes. $^{2}$

A seminal paper by Aschauer (1989a) found a strong impact of infrastructure capital on aggregate TFP, a finding replicated by a number of early studies - for instance Munnell (1990a, 1990b, 1992) for the USA, Mitra et al. (2002) for India, and Easterly and Rebelo (1993) for cross-sectional country data. Similarly, the World Bank's landmark World Development Report 1994 highlighted multiple links between infrastructure and development and emphasized how policy can improve not only the quantity, but also the quality of infrastructure services in developing countries.

However, the economic significance of many of these early results were questioned not only as implausibly large, but as lacking robustness to the use of more sophisticated, and appropriate econometric techniques - see for instance Holtz-Eakin (1994), Cashin (1995) and Baltagi and Pinnoi (1995). While more recently a large body of literature has responded to the identified estimation issues, and reported continued positive and potentially strong economic growth impacts of infrastructure capital, ${ }^{3}$ and infrastructure investments have been explicitly linked with child health, human capital accumulation, and the achievement of the Millennium Development Goals, ${ }^{4}$ countervailing evidence of either ambiguous, ${ }^{5}$ insignificant or negative ${ }^{6}$ impacts of public capital on development prospects continues to emerge also. ${ }^{7}$

\footnotetext{
${ }^{1}$ See for instance Barro (1990). Ghosh and Roy (2002), Gong (2003), Krichel and Levine (2001), Sanchez-Robles (1998a) and Mourmouras and Tijerina (1997) provide extensions and modulations.

${ }^{2}$ See, for instance, Chatterjee et al (2003), Devarajan et al (1998), Gong (2003), Ho and Wang (2005), Kalaitzidakis and Kalyvitis (2004), and Mourmouras and Tijerina (1997).

${ }^{3}$ This is true of studies employing: (1.) cross-national data, see for instance Aschauer (1998), Canning (1999), Demetriades and Mamuneas (2000), Hurlin (1999), Leipziger (2001), Miller and Tsoukis (2001), Nourzad (200), Röller and Waverman (2001); (2.) country-specific regional data - see for instance Aschauer (2001), Ayogu (1999), Charlot et al (2003), Destefanis and Sena (2005), Fernandez and Polo (2002), Fuentes Flores and Mendoza Cota (2003), Haughwout (2002), Kemmerling and Stephan (2002), Petraglia (2002), Ramirez (2002), Rovolis and Spence (2002), Salinas Jimenez (2003), Stephan (2003); (3.) country-specific specific infrastructure types - see for instance Everaert and Heylen (2001), Fernald (1999), Shirley and Winston (2004), (4.) aggregate country data - see for instance Badawi (2003), Everaert (2003), Fedderke, Perkins and Luiz (2005), Frutos et al (1998), Herrera (1997), Kalyvitis (2003), Paul (2003), Pereira and Sagales (1999), Ramirez (2000b); and (5.) sectoral data - see for instance Brox and Fader (2005), Fernandez and Montuenga-Gomez (2003), Paul, Sahni and Biswal (2004).

${ }^{4}$ See Leipziger et al. (2003), and Akinbobola and Saibo (2004).

${ }^{5}$ See for instance Bonaglia et al (2000), Lobo and Rantisi (1999), Sanchez-Robles (1998b).

${ }^{6}$ See for instance Canning and Pedroni (2004), Ghafoor and Yorucu (2002), and Thangalevu and Owyong (2000).

${ }^{7} \mathrm{An}$ obvious extension of this empirical literature is an examination of the extent of underinvestment in infrastructure, and its consequences for economic growth. For instance, on the basis of comparative experience from the 1990s, Easterly and Serven (2004) estimate that about one-fifth of Latin American growth underperformance relative to East Asia was directly related to underinvestment in infrastructure, while Esfahani and Ramirez (2003) estimate that sub-Saharan Africa's poor growth performance was in part related to underinvestments in electricity and telecom infrastructure, and Eustache (2005) estimates that if Africa had enjoyed Korea's quantity and quality of infrastructure, it would have raised its annual growth per capita by about 1 percentage point. Bajo-Rubio and Diaz-Roldan (2005) examine underprovision of public capital for Spanish regions, while Miller and Tsoukis (2001) infer sub-optimal provision of public capital for a larger set of countries. Given anticipated infrastructure impacts on human welfare and equity across community and income groups, further questions surround relative access to infrastructure services across urban and rural households, and different income groups. Often the lowest household income groups have no
} 
Early overviews of the empirical literature can be found in Gramlich (1994) and Hakfoort (1996), while Makin and Paul (2003) provide an update.

At least five potential reasons for the contradictory empirical findings on the growth impacts of infrastructure have been advanced in the literature. ${ }^{8}$ The first proposes that the relationship between public capital and output may be non-linear, with the corollary that both under- and overinvestment in infrastructure are feasible. Which applies in any given context, then becomes a matter for empirical determination. Thus non-linearity is implicit in the model proposed by Barro (1990). Canning and Pedroni (2004) provide an explicit treatment of this possibility, and find that both under- and over-provision of infrastructure applies across countries. See also Seung and Kraybill (2001) and Nourzad (2001).

A second possible reason for any finding of negative impacts of public capital on output and/or growth, may be the presence of crowd-out effects from public investment. The possibility was identified from the outset in this strand of literature - see Aschauer (1989c). Yakita (2004) theoretically identifies such a possibility where the elasticity of substitution between public and private capital is sufficiently small. Desus and Herrera (1999) report empirical findings in support of a crowd-out effect for a panel of 28 developing countries over the 1981-91 period, while Lachler and Aschauer (1998) find a limited crowd-out present for Mexico.

The possibility of endogeneity of infrastructure measures has been advanced as a third possible reason for contradictory findings on public capital impacts on long run economic development indicators. Bias and inconsistency of standard estimators in the presence of simultaneity in the infrastructure measures would follow where infrastructure provision itself positively responds to productivity gains. Possible reasons for such a feedback would arise under increased reliance on the private sector for the provision of infrastructure services, ${ }^{9}$ or under successful lobbying by industry interest groups that experience either positive productivity gains or constraints on performance due to infrastructure provision. Various panel data and country studies tried to address this issue. Thus Röller and Waverman (2001) explicitly model and estimate the impact of telecommunications under simultaneity. In a cross country panel estimation Calderón and Servén $(2003,2005)$ employ GMM panel estimation methods to control for the possibility of endogeneity, reporting significant improvements in results. And Dessus and Herrera (1999) allow for simultaneity in a panel data set for 28 countries. Country-specific time series studies also confirm the presence of simultaneity between output and infrastructure measures - see Frutos et al (1998) for Spain, and Fedderke, Perkins and Luiz (2005) for South Africa.

A fourth possible explanation of contradictory findings on productivity impacts is that public capital may not exercise its impact on output directly, but rather indirectly by raising the marginal product of private sector capital. Under these circumstances, it becomes critical whether the productivity impact is being investigated with respect to output per worker, or with respect to total factor productivity growth. For instance, Reinikka and Svensson (1999) on microeconomic evidence find that poor public capital in Uganda significantly reduces productive private investment - and see also Reinikka and Svensson (2002). Symmetrically, Delorme et al (1999) find no direct impact of infrastructure capital on labor productivity, but do find an impact on aggregate technical efficiency. By contrast, Fedderke Perkins and Luiz (205) find that infrastructure affects both aggregate labor productivity, as well as growth in total factor productivity - though different forms of infrastructure differ in their impacts.

A final possibility that might drive the ambiguous results obtained from empirical studies on public capital impacts on output might simply be that aggregate measures of infrastructure come to hide the productivity impact of infrastructure at a more disaggregated level. Thus for example Shioji (2001) finds that the positive impact of infrastructure emerges in panels of US and Japanese

or extremely limited access to electricity, improved water and sanitation, or basic telephone services. See the more extensive discussion of these issues in Bogetic and Fedderke (2006a) for the South African context specifically.

${ }^{8}$ For the purposes of the present discussion we ignore issues related to data quality.

${ }^{9}$ See the discussion in Estache, Foster and Wodon (2002) and Calderón and Chong (2004). 
industry once public capital is suitably disaggregated.

\section{The Contribution of this Paper}

This paper revisits the question of the productivity impact of public infrastructure, employing a panel from South African manufacturing industry. In particular we investigate the question of whether different forms of infrastructure have a differential impact on productivity growth, whether public capital has both a direct and an indirect impact on productivity growth, and whether controlling for the potential endogeneity of infrastructure has a significant impact on the estimated impact of infrastructure on the direct and indirect productivity measures.

Using South African manufacturing data offers a number of significant advantages in addressing these questions. First, Perkins et al. (2005) has already provided a comprehensive description of particular pattern of economic infrastructural developments in South Africa since 1875. Figure 1, which shows the long-term development of selected infrastructure measures in the form of indices, provides a summary account, and suggests a series of sequential periods of infrastructure roll-out in South Africa. The first wave of infrastructural development was railways over the 1875-1930 period, after which there was little change in the route-kilometer railway line distance - though rolling stock continued to increase. The second take-off in infrastructure investment was in inter-city roads, which reached a plateau around 1940, after which the focus was on the paving of national and provincial roads. In the 1920s and 1930s growth in road traffic far exceeded growth in rail transport, and with the paving of roads after 1940 road traffic continued to grow faster than rail for the rest of the century. While ports constitute South Africa's oldest form of infrastructure, substantial expansion in port capacity was constrained up to the 1970s, at which point two new ports two new ports were constructed, doubling the volume of cargo handled. The final phase of infrastructural development was in telephones and electricity. While the average growth rate for fixed phone lines dropped in the 1960s, it rose again in response to the introduction of information and cell phone technology.

Second, on the basis of aggregate evidence Fedderke, Perkins and Luiz (2005) has already confirmed not only a positive impact of infrastructure on aggregate economic growth for South Africa employing time series analysis, but has established the importance of controlling for feedback effects from output to infrastructure investment. In addition, Bogetić and Fedderke (2006b) provides a natural framework in terms of which the simultaneity of the infrastructure measures employed in this study emerge in a demand for public capital framework, which finds confirmation for South African manufacturing industry. For our purposes, we therefore start not only with the prior that the infrastructure measures will require instrumentation, but we have strong guidance from the literature in terms of likely suitable instruments that can be employed in estimation.

Third, as demonstrated by Figure 1, the economic infrastructure component of South Africa's gross fixed capital formation and fixed capital stock of the public sector (both general government and public corporations) published by the South African Reserve Bank, both demonstrate a longterm deterioration: from the mid-1970s in the case of investment, and from the mid-1980s in the case of fixed capital stock. Specifically, the investment per capita fell from R1 268 in 1976 to R356 in 2002 (in 1995 prices), a collapse of $72 \%$ ! As a percent of GDP, investment fell from $8.1 \%$ of GDP to $2.4 \%$ of GDP, which lies well below the international benchmark of approximately three to six per cent identified by Kessides (1993). The implication is that a finding of negative impacts from public infrastructure capital on our productivity measures should have low probability, at least for the sample period of this study. For a middle-income country the stock of public capital is relatively low, raising the probability that the emerging manufacturing sector of the country should still be experiencing positive productivity gains from infrastructure investment. This provides a set of natural restrictions in estimation, that aids the search for the appropriate specification to be estimated.

Finally, South Africa is a developing country for which infrastructure data is available for long 
(1875-2000) time runs - see the discussion in Perkins et al (2005) - enabling the dynamics of long run growth processes to be explored. Results from the case study thus carry general significance.

Our results confirm that infrastructure has a long-term growth impact in South Africa. Results represent an advance on previous findings in several ways. The paper assesses the productivity impact not only across a wide range of infrastructure measures, but also at a disaggregated level of 3-digit manufacturing sectors. Our sectorally disaggregated evidence finds clearer, and more robust findings of an infrastructure impact on productivity than does the aggregate evidence. It also serves to identify the differential impact of alternative forms of public infrastructure capital. The paper also innovates by investigating the impact of infrastructure both on labor productivity, and on total factor productivity growth, allowing for a clear distinction between the direct and the indirect impact of infrastructure. We find that the isolation of the productivity impact of public infrastructure requires that the infrastructure measures be suitably instrumented, and we propose a general methodology to employ in the construction of instruments for infrastructure measures. Finally, we employ panel estimators that present an advance on the literature, since they allow both for homogeneity of long-run associations across groups included in the panel (homogeneity that is tested for), and for heterogeneity in the short-run dynamics and hence imply differential steady state solutions for the groups included in estimation. Finally, the estimators allow for dynamic rather than instantaneous adjustment of stocks to long-run equilibrium values.

Sections 3 and 4 present the theoretical and econometric frameworks employed in the remainder of the paper. In section 5 we present the empirical evidence. Specifically, section 5.1.1 presents the evidence in the absence of instrumentation for the direct impact of the infrastructure measures on output per worker, section 5.1.3 under instrumental variables estimation. Sections 5.2.1 and 5.2.2 are symmetrical for the indirect impact of infrastructure on total factor productivity. Section 5.1.2 details the instrumentation strategy. Section 6 concludes.

\section{Theoretical Background}

The core rationale for infrastructural investment that emerges from the theoretical literature is that it raises the marginal product of other capital used in production.

Consider a framework in the spirit of Barro (1990). Posit an endogenous growth model in which government owns no capital and produces no services, but purchases private-sector output to provide productive services which serve as inputs in private-sector production or as consumption services to households. The services are purchased without cost recovery under a balanced budget constraint, financed by a flat-rate income tax.

By way of condensed illustration, under closed-economy conditions, Cobb-Douglas technology and homogeneity of degree one, our labor-intensive production function might be:

$$
y=A \cdot g^{\alpha} \cdot k^{1-\alpha}, 0<\alpha<1
$$

where $y$ denotes output per worker, $A>0$ the level of technology, $g$ productive government expenditure (or services) per worker with no congestion effects, and $k$ an inclusive measure of private capital per worker. It follows that the marginal products of $g$ and $k$ are, respectively, $\partial y / \partial g=A \alpha(k / g)^{1-\alpha}>0$, and $\partial y / \partial k=A(1-\alpha)(g / k)^{\alpha}>0$. The positive effect of infrastructure on the marginal product of physical capital is clearly illustrated - analogous to the Arrow (1962) and Romer (1986) learning-by-doing growth models.

Suppose further that a representative, infinitely-lived household seeks to maximize overall utility:

$$
U=\int_{0}^{\infty} u(c) e^{-\rho t} d t
$$

with $u(c)=\left(c^{1-\sigma}-1\right) /(1-\sigma)$, where $c$ is consumption per worker, $-\sigma$ is the elasticity of marginal utility with respect to consumption $(\sigma>0)$, and $\rho>0$ is the constant rate of time preference. 
Since the balanced budget constraint imposes a tax rate of $g / y$, the steady state growth rate, denoted $\gamma$, can be shown to be:

$$
\gamma=\frac{1}{\sigma}\left[\left(1-\frac{g}{y}\right) \cdot A \cdot\left(\frac{g}{k}\right)^{\alpha} \cdot(1-\alpha)-\rho\right]
$$

It follows that:

$$
\frac{d \gamma}{d(g / y)}=\left(\frac{1}{\sigma}\right) \cdot A \cdot\left(\frac{g}{k}\right)^{\alpha} \cdot\left(\frac{\partial y}{\partial g}-1\right)
$$

consider a policy intervention under which $d(g / y)>0$ (given any level of $k$ ). From equation (3) it follows that $\gamma$ decreases due to the tax effect in $g / y$, and increases due to the increase in $g / k$ that is the consequence of the positive effect on the marginal product of $k$. The net effect depends on which of the two impacts is dominant. Since $g / k=(A \cdot g / y)^{1 /(1-\alpha)}$, and hence $d(g / k) / d(g / y)>0$, it follows from equation (4) that the net effect of $d(g / y)>0$ is conditional on the positive but decreasing $\partial y / \partial g$, with $d \gamma / d(g / y)>0$ for $\partial y / \partial g>1, d \gamma / d(g / y)<0$ for $\partial y / \partial g<1$, and $\gamma_{\max }$ at $\partial y / \partial g>1$. Thus the capital productivity effect dominates at low $(g / y)$, and the tax effect at high $(g / y)$.

A clear, theoretical link between output and government infrastructure investment follows. Infrastructure expenditure $(g)$ can prevent diminishing returns to scale in private-sector capital $(k)$, raise the marginal product of private-sector capital $(\partial y / \partial k)$, and raise the rate of growth of output $(\gamma)$. An equally important message is that government intervention of this nature can raise economic growth only within limits, and can have both postive and negative impacts on growth. Once the marginal product of government productive expenditure falls below unity, further increases in $(g / y)$ are harmful to economic growth, since the tax effect comes to dominate the capital productivity effect.

The following subsections outline the relevant methodologies.

\subsection{Infrastructure and Productivity}

We employ two approaches in establishing the existence of an impact of infrastructure on productivity.

The first examines whether infrastructure has an impact on labor productivity. The specification for this exploration is derived from Bogetic and Sanogo (2005). Though the objective of Bogetić and Sanogo (2005) is to isolate factors influencing regional location decisions by industries intranationally in Côte d'Ivoire, implicit within the model is that infrastructure has an impact on labor productivity, and hence will influence decisions on the regional location of industries. The corollary to this link, which finds confirmation for Côte d'Ivoire, is that infrastructure at the national level should certainly impact output per worker. The general specification estimated in Bogetić and Sanogo (2005) is:

$$
\left(\frac{Y}{L}\right)_{i, t}=f\left(\frac{K}{L}, S, U, I\right)_{i, t}
$$

where $Y$ denotes real value added of industry $i$ in period $t, L$ the size of the labor force, $K$ the size of the physical capital stock, $S$ a vector of variables measuring scale economies, $U$ urbanization, and $I$ denotes a vector of variables measuring infrastructural capital stock.

The specification provided by equation (5) is explicit in considering public capital stock to be a factor of production that enters directly into the aggregate production function. Not all models of the impact of infrastructural investment on output follow this route. In Barro (1990), for instance, the impact of public capital on output may indeed be direct, or may exercise its influence by raising the marginal product of the private sector capital stock. Under this specification, infrastructure would impact not on output per worker, but on total factor productivity. 
Given endogenous growth theory, measurement of efficiency improvements must be suitably modified. A useful overview of the computation of TFP growth under endogenous growth is provided by Barro (1998). While there are undoubtedly a number of limitations of growth accounting as a means of isolating technological change, the approach remains in wide-spread use due to the simplicity and consistency of its internal structure. ${ }^{10}$

Perhaps the most significant limitation of the simple decomposition approach for present purposes is the assumption of constant returns to scale. Since endogenous growth theory directs its most fundamental challenge against traditional growth theory on this very assumption, this constitutes a fundamental limitation. Fortunately the limitation can be addressed for estimation purposes. We outline three alternatives corresponding to three alternative conceptions of endogenous growth. Where we have increasing returns due to spill-over effects, it follows that: ${ }^{11}$

$$
\begin{aligned}
T F P & =\frac{\dot{Y}}{Y}-\alpha \frac{\dot{K}}{K}-(1-\alpha) \frac{\dot{L}}{L} \\
& =\frac{\dot{A}}{A}+\beta \frac{\dot{K}}{K}
\end{aligned}
$$

where $\frac{\dot{A}}{A}$ captures exogenous technological progress, and $\beta \frac{\dot{K}}{K}$ captures the spill-over effect due to the factor of production with a weight greater than that implied by its income share (here given by $\alpha$ ). An early example of this approach is given by Grilliches (1979), who proxied for $\frac{\dot{K}}{K}$ by means of R\&D activity. Under the now more conventional approach of Romer (1986), the appropriate growth rate is in terms of physical capital stock, while the Lucas (1988) specification would require additional augmentation with investment in human capital through which the spill-over channel runs in the Lucas specification.

Under a Schumpeterian approach with an increasing variety of intermediate (capital) goods (denoted $X),{ }^{12}$ we have instead:

$$
\begin{aligned}
\text { TFP } & =\frac{\dot{Y}}{Y}-s_{L} \frac{\dot{L}}{L}-s_{X} \frac{\dot{X}}{X} \\
& =\frac{\dot{A}}{A}+b \frac{\dot{N}}{N}
\end{aligned}
$$

where terms are as defined above, $s_{i}$ denotes the income share of factor $i$, and $\frac{\dot{N}}{N}$ denotes the endogenous expansion of intermediate (capital) good varieties (i.e. technological progress). Under the alternative Schumpeterian quality ladders conception $^{13}$ a symmetrical derivation follows, with the $\frac{\dot{N}}{N}$ term coming to denote the overall quality growth rate instead of the variety growth rate. The only remaining difference between the two Schumpeterian conceptions relates to the $b$ coefficient. Under the varieties approach, $b$ can be shown to equal $(1-\alpha)$ where $\alpha$ has the usual elasticity

\footnotetext{
${ }^{10}$ The literature on growth accounting, its strengths and weaknesses, has come to be vast since the contributions of Denison $(1962,1967,1974)$. The first crucial limitation of simple decomposition approaches is that its factor inputs are not disaggregated by quality classes, with resultant upward bias in TFP measures. See, for instance, Jorgenson and Griliches (1967), and Jorgenson, Griliches and Fraumeni (1987). Our empirical results reflect further on this. A second limitation attaches to the assumption that factor social marginal products coincide with observable factor prices. One response to this difficulty is provided by recourse to a regression approach, in order to obtain direct evidence on factor elasticities. However, the regression approach is subject to its own, and severe limitations, since factor input growth rates are likely endogenous, and factor input growth rates are likely to be subject to considerable measurement error. Both Hulten (2001) and Bosworth and Collins (2003) confirm the continued usefulness of TFP computations.

${ }^{11}$ For a fuller discussion of this and the following derivations see Barro (1998).

${ }^{12}$ In the Romer (1990) or Grossman and Helpman (1991: ch3) vein.

${ }^{13}$ See the discussion in Aghion and Howitt (1992) and Grossman and Helpman (1991: ch4).
} 
interpretation with respect to intermediate inputs, while under the quality ladder interpretation $0<b<1$, with $b \rightarrow 1$ associated with "high," and $b \rightarrow 0$ denoting "small" quality differentials.

The usual proxy for the $\frac{\dot{N}}{N}$ term under both Schumpeterian approaches is given by the ratio of the flow of $R \& D$ to the market value of the stock of past $R \& D$. While the flow measure is generally readily available, the stock measure is not. Fortunately, from the relationship given by equation (7) it can be readily demonstrated that $T F P$ growth is linear in the ratio of the $\mathrm{R} \& \mathrm{D}$ flow measure to per capita output, easing the requirements of empirical specification. ${ }^{14}$

A remaining problem with the empirical specification is that a danger of simultaneity bias continues to lurk in the above specifications. Where R\&D proves successful in stimulating TFP growth, firms have an incentive to respond by raising $R \& D$ expenditure further. There is thus no reason to suppose that $\mathrm{R} \& \mathrm{D}$ activity would not respond to changes in productivity growth. In order to obtain reliable estimation results it is thus important to instrument the R\&D measure. The most generic instruments relate to government policies toward R\&D, the registration of patents, and other variables relating to the general enabling environment for private sector $R \& D$ activity (most of $R \& D$ in South Africa is private sector based).

$R \& D$ has found empirical support as a determinant of productivity growth. ${ }^{15}$ Of course, innovation is unlikely to be determined by a single dimension such as R\&D activity, however that is conceived. The empirical and theoretical literature has identified a range of other relevant conditioning variables,${ }^{16}$ including industrial bargaining characteristics ${ }^{17}$ product market characteristics (essentially industry concentration),${ }^{18}$ labor quality and human capital, ${ }^{19}$ trade, international competition or openness of the economy ${ }^{20}$ foreign direct investment, ${ }^{21}$ financial liberalization, and exchange rate overvaluation. ${ }^{22}$

Here we consider the possibility that infrastructure may similarly affect growth in TFP. ${ }^{23}$

We proceed with an application to South African data.

\section{The Data and the Econometric Methodology Employed}

\subsection{The Data}

The empirical work of this paper employs aggregate data for South Africa, manufacturing sector data for South Africa, as well as data from a panel of countries on which infrastructure data is available. Choice of the manufacturing data is determined by data reliability.

In the empirical section employing the manufacturing sector data, we employ a panel data set for purposes of estimation, with observations from 1970 through 1997. The panel employs data for

\footnotetext{
${ }^{14}$ Thus we can replace $\frac{R \& D \text { Flow }}{\text { Market Value of Past } R \& D}$ with $\frac{R \& D \text { Flow }}{Y / L}$.

${ }^{15}$ See for instance Lichtenberg and Siegel (1991), and Hall and Mairesse (1995).

${ }^{16}$ In addition to the conditioning variables specified, the literature has also identified the regulatory environment as relevant. See, for instance, the discussion in Pakes and McGuire (1994), Hopenhayn and Rogerson (1993) and Olley and Pakes (1996). Since we have data only on financial liberalization for South Africa, we do not pursue this line of enquiry further in this paper.

${ }^{17}$ See for instance Nickell (1996), Freeman and Medoff (1981).

${ }^{18}$ See Nickell (1996), Haskel (1991) and Haskel and Slaughter (2001), Baily, Hulten and Campbell (1992), Lichtenberg (1992), McGuckin and Sang (1995), and Jovanovic (1982).

${ }^{19}$ See, for example, the findings in Doms, Dunne and Troske (1997), and Entorff and Kramarz (1998). In a somewhat different tradition, see Nelson and Wright (1992) and Fagerberg (1994).

${ }^{20}$ See Grossman and Helpman (1991), Rivera-Batiz and Romer (1991), Coe and Helpman (1995), Coe, Helpman and Hoffmaister (1997), Keller (1998), Benhabib and Spiegel (1994), Haskel and Slaughter (2001), Mayer (2001), Sala-i-Martin et al (2004), Bosworth and Collins (2003), Sachs and Warner (1995). See also the discussion in Tybout (2000) with respect to developing country manufacturing sectors, and Bernard and Jensen (1995), Clerides, Lach and Tybout (1998), Doms and Jensen (1998), and Bernard and Jensen (1999).

${ }^{21}$ See De Mello (1997) and Ramirez (2000a), and Fedderke and Romm (2005) for an application to South Africa.

${ }^{22}$ See Rajan and Subramanian (2005).

${ }^{23} \mathrm{An}$ earlier paper employs a symmetrical methodology to investigate a wide range of other impacts on TFP growth - see Fedderke (2005).
} 
22 three-digit SIC version 5 manufacturing sectors in the South African economy for which data is available. The list of sectors included in the panel is that specified in Table 1. This provides a $22 \times 28$ panel with a total of 616 observations. $^{24}$

Variables for the manufacturing sector include the output, capital stock, and labor force variables and their associated growth rates. For data on TFP growth in South African manufacturing, we rely on Fedderke (2002).

To control for the market conditions firms face, and other determinants of productivity, we also employ: ${ }^{25}$

- The skills mix of the labor force in each manufacturing sector. The ratio is of high and medium skill levels to unskilled labor. We denote the variable as SKRAT. Since TFP decompositions in South Africa do not control for changing skills composition of the labor force, it is vital to control for the skills ratio in any determination of TFP, in order to correct for the resultant upward bias in the TFP measure. ${ }^{26}$

- The net export ratio of each manufacturing sector, ${ }^{27}$ incorporated in the hypothesis in the literature that export competitiveness may require strong innovative capacity. We denote the variable as NX.

- $R \& D$ expenditure by manufacturing sector is compiled from published survey data on $R \& D$ expenditure. Data is collected for private sector $R \& D$ expenditure, public sector $R \& D$ expenditure, and expenditure by tertiary educational institutions earmarked for each of the 28 manufacturing sectors. ${ }^{28}$ All expenditure is real.

- Two measures of industry concentration, given by the Gini index and Rosenbluth index are computed for each industry in each year over the sample period. Data is obtained from Fedderke and Szalontai (2005). We denote the variables GINI and ROSEN respectively.

- The total number of patents registered in South Africa, in order to serve as a proxy for the quality of intellectual property rights. ${ }^{29}$ We denote the variable as PATENT.

- An index of property rights in South Africa, as a second proxy for the quality of the property rights environment. The hypothesis is that the general quality of property rights may impact on the quality of intellectual property rights. ${ }^{30}$ We denote the variable as PROPERTY.

From Perkins, Fedderke and Luiz (2005) we obtain measures of infrastructure capital stock and investment defined as follows:

- Economic infrastructure:

- Gross fixed capital formation in infrastructure, denoted GFCF (1995 prices).

- Fixed capital stock of infrastructure, denoted FCS (1995 prices).

\footnotetext{
${ }^{24}$ In general, South Africa reports data on 28 3-digit manufacturing sectors. Some of these had to be excluded from the analysis for reasons of data availability. Television, radio \& communications equipment and Professional \& scientific equipment did not have data on R\&D expenditure, while Tobacco, Plastic products, Television, radio \& communications equipment and Other transport equipment lacked data on labour force skills levels. Petroleum products lacked consistent information on industry concentration.

${ }^{25} \mathrm{~A}$ fuller discussion of these data and their quality see Fedderke (2005).

${ }^{26}$ See the more detailed discussion of this point in Fedderke (2002).

${ }^{27}$ Computed as $\frac{X}{X+I M}$ where $X$ denotes exports, and $I M$ imports.

${ }^{28}$ The surveys are the Resources for $R \mathscr{E} D$ surveys undertaken by the Office of the Scientific Adviser to the Prime Minister/President and the Council for Scientific and Industrial Research (CSIR). Full details of this data available from authors on request.

${ }^{29}$ For details on the construction of this variable see Fedderke, de Kadt and Luiz (2001).

${ }^{30}$ For details on the construction of this variable see Fedderke, de Kadt and Luiz (2001).
} 
- Railways:

- Open railway lines, denoted RAIL (route kilometers).

- Locomotives, denoted LOCO (total number steam, diesel and electric).

- Coaching stock, denoted COACH (number).

- Goods stock, denoted GOODS (number).

- Carrying capacity of goods stock, denoted CCAP (tonnes).

- Passenger journeys, denoted RPASS (number).

- Revenue-earning traffic, denoted RFRT.

- Roads:

- Total distance, denoted TRDS (kilometers).

- Paved distance, denoted PRDS (kilometers).

- Passenger vehicles, denoted VEHP (number).

- Commercial (goods) vehicles, denoted VEHG (number).

- Ports:

- Cargo handled, denoted PORTS (harbour tonnes).

- Air Travel:

- Passengers carried by South African Airways, denoted SAA (number).

- International passengers passing through South African airports, denoted APASS (number).

- Telecommunications:

- Fixed phone lines, denoted FTEL (number).

- Total phone lines (fixed + mobile), denoted TEL (number).

- Power generation: electricity generated, denoted ELEC (gigawatt hours).

\subsection{The Econometric Methodology: The Panel Analysis}

For the panel data analysis, we employ the Pooled Mean Group (PMG) estimator of Pesaran, Shin and Smith (1999).

Consider the unrestricted error correction $\operatorname{ARDL}(p, q)$ representation:

$$
\Delta y_{i t}=\phi_{i} y_{i, t-1}+\boldsymbol{\beta}_{i}^{\prime} \mathbf{x}_{i, t-1}+\sum_{j=1}^{p-1} \lambda_{i j} \Delta y_{i, t-j}+\sum_{j=0}^{q-1} \boldsymbol{\delta}_{i j}^{\prime} \Delta \mathbf{x}_{i, t-j}+\mu_{i}+\varepsilon_{i t},
$$

where $i=1,2, \ldots, N, t=1,2, \ldots, T$, denote the cross section units and time periods respectively. Here $y_{i t}$ is a scalar dependent variable, $\mathbf{x}_{i t}(k \times 1)$ a vector of (weakly exogenous) regressors for group $i$, and $\mu_{i}$ represents fixed effects. Allow the disturbances $\varepsilon_{i t}$ 's to be independently distributed across $i$ and $t$, with zero means and variances $\sigma_{i}^{2}>0$, and assume that $\phi_{i}<0$ for all $i$. Then there exists a long-run relationship between $y_{i t}$ and $\mathbf{x}_{i t}$ :

$$
y_{i t}=\boldsymbol{\theta}_{i}^{\prime} \mathbf{x}_{i t}+\eta_{i t}, i=1,2, \ldots, N, t=1,2, \ldots, T,
$$


where $\boldsymbol{\theta}_{i}=-\boldsymbol{\beta}_{i}^{\prime} / \phi_{i}$ is the $k \times 1$ vector of the long-run coefficients, and $\eta_{i t}$ 's are stationary with possibly non-zero means (including fixed effects). This allows (8) to be written as:

$$
\Delta y_{i t}=\phi_{i} \eta_{i, t-1}+\sum_{j=1}^{p-1} \lambda_{i j} \Delta y_{i, t-j}+\sum_{j=0}^{q-1} \boldsymbol{\delta}_{i j}^{\prime} \Delta \mathbf{x}_{i, t-j}+\mu_{i}+\varepsilon_{i t},
$$

where $\eta_{i, t-1}$ is the error correction term given by (9), and thus $\phi_{i}$ is the error correction coefficient measuring the speed of adjustment towards the long-run equilibrium.

This general framework allows the formulation of the PMG estimator, which allows the intercepts, short-run coefficients and error variances to differ freely across groups, but the long-run coefficients to be homogenous; i.e. $\boldsymbol{\theta}_{i}=\boldsymbol{\theta} \forall i$. Group-specific short-run coefficients and the common long-run coefficients are computed by the pooled maximum likelihood estimation. Denoting these estimators by $\tilde{\phi}_{i}, \tilde{\boldsymbol{\beta}}_{i}, \tilde{\lambda}_{i j}, \tilde{\boldsymbol{\delta}}_{i j}$ and $\tilde{\boldsymbol{\theta}}$, we obtain the PMG estimators by $\hat{\phi}_{P M G}=\frac{\sum_{i=1}^{N} \tilde{\phi}_{i}}{N}, \hat{\boldsymbol{\beta}}_{P M G}=\frac{\sum_{i=1}^{N} \tilde{\boldsymbol{\beta}}_{i}}{N}$, $\hat{\lambda}_{j P M G}=\frac{\sum_{i=1}^{N} \tilde{\lambda}_{i j}}{N}, j=1, \ldots, p-1$, and $\hat{\boldsymbol{\delta}}_{j P M G}=\frac{\sum_{i=1}^{N} \tilde{\boldsymbol{\delta}}_{i j}}{N}, j=0, \ldots, q-1, \hat{\boldsymbol{\theta}}_{P M G}=\tilde{\boldsymbol{\theta}}$.

PMG estimation provides an intermediate case between the dynamic fixed effects (DFE) estimator which imposes the homogeneity assumption for all parameters except for the fixed effects, and the mean group (MG) estimator proposed by Pesaran and Smith (1995), which allows for heterogeneity of all parameters. It exploits the statistical power offered by the panel through long-run homogeneity, while still admitting short-run heterogeneity. As long as sector-homogeneity is assured, the PMG estimator offers efficiency gains over the MG estimator, while granting the possibility of dynamic heterogeneity across sectors unlike the DFE estimator. In the presence of long-run homogeneity, therefore, our preference is for the use of the PMG estimator.

The crucial question is whether the assumption of long-run homogeneity is justified, given the threat of inefficiency and inconsistency noted by Pesaran and Smith (1995). We employ a Hausman (1978) test (hereafter $h$ test) on the difference between MG and PMG estimates of long-run coefficients to test for long-run heterogeneity. ${ }^{31}$ Note that as long as the homogeneity Hausman test is passed in our estimations, we report only PMG estimation results. ${ }^{32}$

Finally, it is worth pointing out that a crucial advantage of the estimation approach of the present paper, is that the dynamics generally argued to be inherent in growth processes are explicitly modelled, while recognizing the presence of a long-run equilibrium relationship underlying the dynamics. This is particularly important given the recurrent debate in the context of growth studies concerning the appropriate length of the time window used in averaging data for cross country studies. Justification for averaging rests on the need to remove short-run fluctuations in growth studies. The choice of any window is in the final instance arbitrary. ${ }^{33}$ Thus the justification for the use of the PMG estimator is that it is consistent both with the underlying theory of an homogenous long-run relationship, while allowing for the explicit modelling of short-run dynamics around the long-run relationship, and the possibly heterogeneous dynamic time series nature of the data in the dynamics of adjustment.

\subsection{The Econometric Methodology: The Time Series Analysis}

Our estimation is of structural systems by standard time series techniques, with variables that are first-difference stationary. Johansen ${ }^{34}$ techniques of estimation are now standard, so that discussion of estimation methodology here can be brief. We employ a vector error-correction mechanism

\footnotetext{
${ }^{31}$ An alternative is offered by Log-Likelihood Ratio tests. However, the finite sample performance of such tests are generally unknown and thus unreliable. We therfore employ the h-test instead.

32 The author thanks Yongcheol Shin for the provision of the appropriate GAUSS code for estimation purposes.

${ }^{33}$ Indeed, some panel studies do not average at all. Unfortunately the estimators used in turn are generally not dynamic, so that the results obtained may also be driven by short-term fluctuations.

${ }^{34}$ See Johansen (1991) and Johansen and Juselius (1990).
} 
(VECM) framework, for which, in the case of a set of $\mathrm{k}$ variables, we may have cointegrating relationships denoted $r$, such that $0 \leq r \leq k-1$. This gives us a k-dimensional VAR:

$$
z_{t}=A_{1} z_{t-1}+\cdots+A_{m} z_{t-m}+\mu+\delta_{t}
$$

where $m$ denotes lag length, a $\mu$ set of deterministic components and $\delta$ a Gaussian error term. Reparameterization provides the VECM specification:

$$
\Delta z_{t}=\sum_{i=1}^{k-1} \Gamma_{i} \Delta z_{t-i}+\Pi z_{t-k+1}+\mu+\delta_{t}
$$

The existence of $r$ cointegrating relationships amounts to the hypothesis that:

$$
H_{1}(r): \Pi=\alpha \beta^{\prime}
$$

where $\Pi$ is $p x p$, and $\alpha, \beta$ are $p x r$ matrices of full rank. $H_{1}(r)$ is thus the hypothesis of reduced rank of $\Pi$. Where $r>1$, issues of identification arise. ${ }^{35}$ Estimation is by VECM cointegration.

\section{$5 \quad$ Empirical and Estimation Results}

As discussed in the theoretical background to the paper, we investigate two separate productivity impacts of infrastructure. The first follows Bogetić and Sonogo (2005) in estimating the impact of infrastructure on output per worker, in effect allowing infrastructure to enter the aggregate production function of the economy directly. The second allows for an indirect impact of infrastructure on productivity, through TFP growth, within an endogenous growth framework.

\subsection{The Impact of Infrastructure on Output per Employee}

In this section we follow Bogetić and Sanogo (2005) in exploring the impact of infrastructure on output per worker.

An empirical model of the general specification given by equation (5) is provided by: ${ }^{36}$

$$
\left(\frac{Y}{L}\right)_{i, t}=\alpha+\beta_{k}\left(\frac{K}{L}\right)_{i, t}+\beta_{I} I_{i, t}+\beta_{X} X_{i, t}+\varepsilon_{i, t}
$$

where all variables are as defined as before, $I_{i, t}$ is provided by a vector of infrastructure measures as defined in the data section of the paper, and $X_{i t}$ denotes a vector of additional relevant variables. Here we incorporate a range of additional variables that may be relevant to labor productivity, including the net export ratio of the industry as an indicator of the openness of the sector, denoted $N X_{i, t}$, industry concentration in liu of scale effects, denoted $G I N I_{i t}$, and the skills ratio of the labor force, denoted $S K R A T_{i, t}$.

\subsubsection{Results in the Absence of Instrumentation}

Estimation is by means of the PMG panel estimator for South African manufacturing sectors. Results are reported in Tables $2 \mathrm{~A}$ and $2 \mathrm{~B}$.

For all specifications estimation results confirm not only adjustment to equilibrium, but a rapid adjustment (see the $E C M$-parameters, which correspond to the $\phi$-parameters of equation 8). Moreover, in general, the Hausman tests (denoted $h$-tests) confirm the legitimacy of the PMG estimator

\footnotetext{
${ }^{35}$ See Wickens (1996), Johansen and Juselius (1990, 1992), Pesaran and Shin (1995a, 1995b), Pesaran, Shin and Smith (1996).

${ }^{36}$ Bogetić and Sanogo (2005) employ the ratio of cumulative investment to employment instead of the capital labour ratio. Given the availability of capital stock data for South Africa, we employ the direct measure of capital intensity.
} 
by failing to reject the homogeneity restriction on the long-run coefficients for South African manufacturing sectors at conventional levels of significance - the only exceptions occur in columns (12) of Table 2A, and (21) of Table 2B in the specifications controlling for revenue earning rail traffic and fixed telephone lines respectively. Given the unknown finite sample properties of the LR test statistic, we thus proceed on the assumption of long-run parameter homogeneity. Finally, we note also that lag structure is stable across specifications, while parameter stability, with a few exceptions on which we comment below, is notable also.

The capital labor ratio proves to have the positive and statistically significant impact on labor productivity expected from standard economic theory. The implied constant output elasticity centers on the $0.3-0.4$ range, which again conforms to prior theoretical and empirical expectations. The only exceptions occur in the specifications controlling for paved roads, either passenger of goods vehicles, and electrification, for which the output elasticity rises to above unity, a level that is not easy to explain. High output elasticities also appear in the specifications that control for railway rolling stock (lnCOACH, lnGOODS) and telecommunications (lnFTEL, lnTEL).

Industry concentration is consistently found to be statistically insignificant. Columns (1) and (2) of Table 2A reports two alternative specifications which include the GINI measure of industry concentration, which both prove to be insignificant. ${ }^{37}$

A more surprising finding is that the skills ratio of manufacturing employment consistently proves statistically significant, but with a negative impact on labor productivity. While a negative sign is expected in a TFP growth equation (to account for an incomplete accounting for improvements in labor productivity), the finding is more difficult to explain in the context of output per worker. One possible interpretation may be that the long history of South African underinvestment in human capital $^{38}$ may have come to create a supply side constraint on industries that rely on a strong complementarity between human and physical capital. ${ }^{39}$ The negative sign on the skills ratio may be a reflection of the fact that industries with a strong human capital requirement have not been able to hire the requisite form of labor, and have therefore maintained a lower investment rate. Thus the poorly conceived educational policies of past South African governments may have served to generate the additional negative consequence of lowering investment in knowledge intensive sectors of the economy. While we remain uncertain as to the precise interpretation of the negative coefficient, its consistent statistical significance suggested its inclusion in estimation throughout.

Net exports consistently have a positive impact on labor productivity in the manufacturing sectors in South Africa, and the variable is statistically significant throughout. Parameter stability across the estimated specifications holds in general, with estimated coefficients of approximately 0.15 . The NX measure spans the range from -0.97 to 0.84 in the study sample. Thus an increase of 0.1 in the NX measure constitutes an increase of approximately $5 \%$ in the net export ratio over the total sample range in South African manufacturing. For a parameter value of 0.15, the implication is that labor productivity would improve by $1.5 \%$ per annum due to the 0.1 ( $5 \%$ of sample range) improvement in the net export ratio, suggesting a fairly sensitive response to international exposure of the South African manufacturing sectors. ${ }^{40}$ Learning opportunities from exposure to international markets thus appear to be significant for South African manufacturing. ${ }^{41}$

Finally, results confirm the presence of a consistent, and economically significant impact of infrastructure on labor productivity.

The two aggregate measures of economic infrastructure, lnGFCF and lnFCS, carry negative

\footnotetext{
${ }^{37}$ The alternative Rosenbluth measure of industry concentration proved similarly insignificant. We also employed a number of alternative specifications including industry concentration measures, which consistently proved insignificant. We therefore report the more parsimonious specifications excluding industry concentration for the remainder of this subsection.

${ }^{38}$ See the more detailed exposition in Fedderke, De Kadt and Luiz (2000, 2003), and Fedderke and Luiz (2002).

${ }^{39}$ The shortage of skills has become a recurring policy issue in South Africa over the past decade.

${ }^{40}$ Note that the implication is of a variable elasticity over the sample range.

${ }^{41}$ This confirms the finding already established in Fedderke (2005), though in the latter paper the focus is on TFP growth.
} 
and positive signs respectively, suggesting that while infrastructure investment (lnGFCF) carries a crowd-out effect with respect to private sector labor productivity, this effect is not persistent, since the impact of the infrastructure capital stock is positive. Moreover, at an elasticity of -0.05 the negative impact on labor productivity is economically small. On the other hand, only the infrastructure investment measure proves to be statistically significant.

The railway measures consistently report not only a positive elasticities with respect to labor productivity, but often prove to be strongly related to labor productivity. In only two instances are the measures of railway infrastructure statistically insignificant, for the number of locomotives (lnLOCO) and number of railway passenger journeys (lnRPASS). The extensiveness of the railway network (the kilometers of railway track - lnRAIL) returns a very strong labor productivity elasticity of 1.16, and the carrying capacity of goods stock (lnCCAP) is also strong at approximately 0.6. Even the two statistically significant elasticities for the goods stock (lnGOODS) and revenue earning traffic (lnRFRT) are relatively strong at approximately 0.4 and 0.2 respectively.

By contrast to the rail infrastructural measures, the measures of road infrastructure employed by this study are either statistically insignificant (total roads - lnTRDS), or report a statistically significant but perverse impact on labor productivity. The impact of paved roads (lnPRDS) is particularly strong at a negative unitary elasticity, but both the number of passenger (lnVEHP) and goods vehicles (lnVEHG) have strong negative elasticities of approximately -0.50 also. This result deserves further study. Our preliminary conjecture is that this may reflect the territorial distribution and expansion of roads in part driven by non-economic objectives of the Apartheid era.

The remaining transport infrastructure measures all report positive labor productivity elasticities. Both the cargo handled by ports (lnPORTS) and air passenger traffic (lnSAA) have statistically significant elasticities in the $0.2-0.3$ range, and only aggregate air passenger traffic (lnAPASS) is statistically insignificant (the elasticity remains positive, though economically negligible at 0.04).

In contrast to the aggregate findings for South Africa, ${ }^{42}$ electricity generation is negatively, statistically significantly, and economically strongly related to labor productivity in the manufacturing sector of South Africa, with an elasticity of -0.4.

Finally, all telecommunications measures (lnFTEL for fixed lines, and lnTEL for total telephone connections) and the urbanization rate (URB) in South Africa prove to be statistically insignificant.

In summary, therefore, the findings on the impact of infrastructure on South African manufacturing sector labor productivity suggest that both statistical and economic significance attaches to transport infrastructure in various dimensions. Strong positive impacts on manufacturing labor productivity appear to attach to railway and ports infrastructure, while roads infrastructure have the opposite effect, and telecommunications have little impact.

\subsubsection{Instrumentation for Infrastructure Stocks}

A concern with the baseline estimations reported in section 5.1.1, is that they ignore the possibility of endogeneity. Where infrastructure has a significant impact on productivity, this may trigger increased investment flows into infrastructure. Industrial policy intervention, private sector and trade union lobbies may all provide behavioural or policy mechanisms by means of which feedback effects from productivity to infrastructure measures are realized.

Where such feedback mechanisms are present, the need for appropriate instrumentation in estimation arises. One way of proceeding here is by reference to the literature on identifying infrastructure demand. ${ }^{43}$

Fay (2001) and Fay and Yepes (2003) develop a methodology designed to identify the physical needs in infrastructural stocks. Basis of the methodology is the interaction of a demand for

\footnotetext{
${ }^{42}$ See Fedderke, Perkins and Luiz (2005).

${ }^{43}$ This approach has already been employed in order to forecast infrastructure demand in South Africa for electricity and telecommunications. See Bogetic and Fedderke (2006b).
} 
infrastructure, based on utility maximizing consumers, such that:

$$
I_{j}^{C}=f\left(Y_{j}, q_{I}\right)
$$

where $I_{j}^{C}$ denotes the consumption of infrastructure by individual $j, Y_{j}$ denotes $j / s$ income, and $q_{I}$ the price of infrastructure. Profit maximization on the production side of the economy provides the standard first order condition:

$$
\frac{\partial Y_{i}}{\partial I_{i}^{P}}=\frac{q_{I}}{w_{i}}
$$

where $Y_{i}$ denotes the $i$ th firm's output, $w_{i}$ the $i$ th firm's output price, and $I_{i}^{P}$ the production use of infrastructure.

This framework leads Fay (2001) and Fay and Yepes (2003) to the formulation of a reduced form demand for infrastructure in per capita format:

$$
\frac{I}{P}=F\left(\frac{Y}{P}, \frac{q_{I}}{w}, Y_{a g}, Y_{i n d}, A\right)
$$

where $P$ denotes population, $Y_{a g}$ and $Y_{\text {ind }}$ the output of the agricultural and industrial sectors respectively, ${ }^{44}$ and $A$ denotes technology. In estimation, Fay (2001) and Fay and Yepes (2003) employ fixed effects estimation, in which fixed effects are to control for the unobservable aggregate infrastructure price, $\frac{q_{I}}{w}$, and technology dimensions. Application is to Latin America, as well as a wider set of countries. ${ }^{45}$

Empirically we proceed with two instrumentation strategies. The first instruments only on per capita output, ${ }^{46}$ the second also controls for the share of the agricultural and industrial sectors in aggregate South African GDP. Tables 3 and 4 report deviations between the conditional mean predicted demand for the infrastructural stocks employed for this study, and the actual stock of infrastucture reported for South Africa, for decade averages in absolute and percentage terms, for estimation results derived under the time series methodology described under section $4.3{ }^{47}$

In Table $5 \mathrm{~A}$ and $5 \mathrm{~B}$ we report the correlations between the two alternative instruments and original regressors, and the two alternative dependent variables used in this paper as measures for productivity, output per worker and the Solow residual. For both instruments, correlations with the original regressors is relatively high, while correlations with the productivity measures is low, strengthening confidence in the use of the two instruments. In general, we note that the instrument which loads on sector shares (agriculture, industry), is more highly correlated than the instrument loading only on per capita GDP. Exceptions emerge for a number of the railways-related measures (LOCO, COACH, GOODS, CCAP, RPASS), and one roads infrastructure measure (VEHP).

Given this evidence, we proceed with estimation using instruments.

\subsubsection{Results in the Presence of Instrumentation}

Estimation is again of equation (14) by means of the PMG panel estimator for South African manufacturing sectors, with the exception that the infrastructure measure is now replaced by the instrumented measure. Results are reported in Tables 6A and 6B.

\footnotetext{
${ }^{44}$ These are admittedly somewhat ad hoc proxies that substitute for the aggregation issues that arise from developing industry demand from firm level demand functions.

${ }^{45}$ An alternative approach to establishing an appropriate level of infrastructural expenditure, is provided by Randolph, Bogetić and Hefley (1996). The conditional mean of infrastructural expenditure in their model is determined by a wide range of regressors, including the existing stock of infrastructure, population density, the urbanization rate, the urban-rural balance, the labour force participation rate, per capita GDP, the internal and external balances, size of the foreign sector, terms of trade shifts, debt obligations, the level of institutional development, level and mix of foreign funding, and the degree of anti-poverty commitment on the part of government.

${ }^{46}$ We employ the aggregate per capita GDP measure from Fedderke and Romm (2006).

${ }^{47}$ Full estimation results and diagnostics available on request.
} 
For all specifications, estimation results confirm adjustment to equilibrium (see the ECMparameters, which correspond to the $\phi$-parameters of equation 8). Moreover, for all specifications the Hausman tests (denoted $h$-tests) confirm the legitimacy of the PMG estimator by failing to reject the homogeneity restriction on the long-run coefficients for South African manufacturing sectors.

The capital-labor ratio, the skills ratio and the net export ratios continue to report statistical significance, and the direction of association already discussed under section 5.1.1. Since these variables have already been the subject of discussion, we focus on results for the infrastucture measures under instrumentation instead.

In short, under instrumentation the general finding for the infrastructure measures is that statistical significance of the infrastructure is now uniform (with the exception of the PORTS measure), and in general the elasticity of labor productivity with respect to the infrastructure measures is higher than in the absence of IV estimation.

The two aggregate measures of economic infrastructure, the stock and the investment flow given by lnGFCF and lnFCS respectively, are now both positive and statistically significant, with elasticities of 0.20 and 0.19 . Under instrumentation, controlling for possible endogeneity, the short-run crowd out effect noted in section 5.1.1 is now absent, with both short run and long run effects of infrastructure testing positive.

The railway measures consistently report statistically significant and economically strong positive elasticities with respect to labor productivity - with no exception. Specifically, the extensiveness of the railway network (the kilometers of railway track - lnRAIL) returns a strong labor productivity elasticity of 0.81 , the number of locomotives (lnLOCO) and the goods stock (lnGOODS) return elasticities of 1.04 and 1.03 respectively, with coaching stock $(\mathrm{lnCOACH})$ returning a somewhat lower elasticity of 0.39 . The carrying capacity of goods stock (lnCCAP) remains strong at an elasticity of 0.68 , while railway passenger journeys.(lnRPASS) and revenue earning traffic have long run elasticities of 0.43 and 0.32 respectively.

Again in contrast to results for un-instrumented infrastuctural measures, all roads infrastructural measures now have statistically significant, positive, and often economically very strong impacts on labor productivity. The total roads measure (lnTRDS) has the strongest elasticity, 2.95, followed by paved roads (lnPRDS), 1.08, passenger and goods vehicles, with elasticities of 0.43 and 0.35 respectively.

Of the remaining transport infrastructure measures, air passenger traffic (lnSAA) reports a statistically significant elasticity of 0.25 , though that for aggregate air passenger traffic is somewhat lower at an elasticity of 0.05 , though it remains statistically significant.

The cargo handled by ports (lnPORTS) measure proves to be the only statistically insignificant infrastructure measure under IV estimation. However, given that the ports infrastucture measure is the relatively most unchanging infrastructure measure over the sample period for estimation in this study, it is also the least likely to suffer from feedback effects from the productivity measure. Hence, the statistically significant, and positive elasticity of 0.18 obtained in the absence of IV estimation, may well be the more plausible measure of the economic impact of port infrastucture.

In contrast to the findings without instrumentation, and in line with the aggregate findings for South Africa, electricity generation is positively, and statistically significantly related to labor productivity in the manufacturing sector of South Africa, with an elasticity of -0.05 , though the impact of electricity generation remains considerably weaker than the finding reported for the economy in aggregate (elasticity of $0.2-0.5$ depending on specification).

Finally, both telecommunications measures (InFTEL for fixed lines, and lnTEL for total telephone connections) return positive and statistically significant elasticities, of 0.05 for fixed lines, and 0.41 for total telephone lines.

In summary, therefore, the findings on the impact of infrastructure on South African manufacturing sector labor productivity suggest that both statistical and economic significance attaches to transport infrastructure in various dimensions. Importantly, accounting for the possibility of feedback effects from output per worker to infrastructure measures, serves to render all infrastruc- 
ture measures but one statistically significant, positive, and in general reports higher impacts of the infrastructure on the labor productivity measures. Figure 2 summarizes the labor productivity elasticities of the infrastructure measures in the absence of, and due to IV estimation.

\subsection{The Impact of Infrastructure on TFP Growth}

In our empirical investigation of an impact of infrastructure on TFP growth we proceed with an estimation of the empirical specification provided by equation (7). As discussed above, this requires regression of growth in total factor productivity on the ratio of $\mathrm{R} \& \mathrm{D}$ expenditure to per capita output. $^{48}$ While the literature also suggests a range of additional factors relevant to the determination of productivity gains, ${ }^{49}$ including labor market conditions, labor quality and human capital, industry concentration, exposure to international competition, foreign direct investment, financial liberalization, and exchange rate overvaluation, these are dealt with in a separate paper, ${ }^{50}$ and here we deal strictly with the impact of infrastructure.

Therefore, we estimate a baseline specification given by:

$$
T F P_{i t}=\alpha+\beta_{R D}\left(\frac{R \& D}{Y / L}\right)_{i t}+\beta_{S K} S K R A T_{i t}+\beta_{N X} N X_{i t}+\beta_{G} G I N I_{i t}+\beta_{Z} Z_{t}+\varepsilon_{i t}
$$

where $Z_{t}$ denotes a vector of the various measures of infrastructure identified in the data section..$^{51}$

An immediate estimation issue concerns the possibility of simultaneity bias attaching to the $\frac{R \& D}{Y / L}$ variable identified in the theoretical discussion. To address this problem we instrument the $\frac{R \& D}{Y / L}$ variable. ${ }^{52}$ While the regressor in equation $(18)$ is constructed with private sector R\&D expenditure, we employ SURE estimations ${ }^{53}$ in order to instrument the private sector R\&D expenditure ratio on public sector $R \& D$ activity and tertiary educational institutions' $R \& D$ activity within each manufacturing sector. ${ }^{54}$ We report the results of the SURE estimations in Table 7 . Reported $\chi^{2}$ test statistics based on equation and system log likelihoods confirm the presence of non-diagonal error covariance matrices throughout, confirming the appropriateness of SURE estimation.

\subsubsection{Results in the Absence of Instrumentation}

Estimation of equation (18) is reported in Tables $8 \mathrm{~A}$ and $8 \mathrm{~B}$. Results again confirm rapid adjustment to equilibrium (see the $E C M$-parameters, which correspond to the $\phi$-parameters of equation 8), and in general the Hausman tests (denoted $h$-tests) confirm the legitimacy of the PMG estimator by failing to reject the homogeneity restriction on the long-run coefficients for South African manufacturing sectors at conventional levels of significance. There are five exceptions to the homogeneity finding, in the specifications controlling for paved roads, passenger and goods motor vehicles, and telecommunications (columns 11, 12, 13, 17 and 18).

\footnotetext{
${ }^{48}$ There is some debate about whether the appropriate productivity measure is provided by labour productivity or total factor productivity. The TFP measure is generally preferred since $Y / L$ may increase due to a rising $K / L$, without technology changes. TFP growth provides more direct information on growth due to technological change, and is the measure employed here.

${ }^{49}$ Bartelsman and Doms (2000) provides a useful overview of the issues beyond the literature already cited above.

${ }^{50}$ See Fedderke (2005).

${ }^{51}$ Note that all of these dimensions are generic to the economy, rather than industry-specific.

${ }^{52}$ Adequate instruments should be correlated with the private sector R\&D variable, but not the TFP term. Public and tertiary R\&D is employed in the current study, since they are likely to show association with the R\&D activity of the private sector, but would not be associated with the innovation in production of the private sector. Correlation of government and tertiary $\mathrm{R} \& \mathrm{D}$ with private sector $\mathrm{R} \& \mathrm{D}$ is 0.44 and 0.31 , respectively; correlation of the two instruments with TFP is 0.01 and 0.02 , respectively, confirming our prior.

${ }^{53} \mathrm{SURE}$ estimation is appropriate on the assumption that contemporaneous correlation of disturbances attaching to growth in total factor productivity across manufacturing sectors may be non-zero - a reasonable assumption confirmed by relevant diagnostics. Given that we have separate R\&D expenditure figures for private, public and tertiary sectors across manufacturing sectors, SURE promises efficiency gains over single equation estimation.

${ }^{54}$ Note, some sectors did not have data on public or tertiary sector R\&D expenditure data available. For these we instrumented on either PATENT (marked $\dagger$ ) or PROPERTY (marked $\ddagger$ ).
} 
A number of the results are symmetrical to those reported in Fedderke (2005). First, results confirm the presence of a positive impact of R\&D expenditure on growth in total factor productivity, as postulated by Schumpeterian theory. The coefficient on the instrumented R\&D measure is consistently positive, and is statistically significant in all but one specification (that controlling for railway locomotives, column 4 of Table $8 \mathrm{~A}$ ). In general, the $\mathrm{R} \& \mathrm{D}$ coefficient proves robust to alternative specifications, ${ }^{55}$ and in most specifications lies in the range from 0.03 to 0.06 . Thus the findings confirm the presence of a positive, and consistent impact on output growth of innovative $R \& D$ activity undertaken by the private sector. Indeed, the only concern with this set of results is that the impact of the $\mathrm{R} \& \mathrm{D}$ activity is potentially too strong to be plausible, since the stable coefficient range implies a more than proportional impact of R\&D on TFP growth. Given the uncertainties surrounding $R \& D$ success, this is surprising, and likely implausibly large.

Second, the variable controlling for the skills composition of the labor force, SKRAT, corrects the TFP measure for its upward bias that results from not correcting the underlying decomposition for improving skills levels. Accordingly, the impact of the SKRAT variable proves to be consistently negative, as well as statistically significant in all estimations. What is more, parameter-values are consistently in the -0.03 to -0.05 range.$^{56}$ The inference is that the TFP decomposition does serve to bias upward the measure of technological progress, with at least some of the efficiency gain in production proving attributable to increasing skills levels in the labor force.

Third, net exports consistently have a positive impact on the innovative activity of the manufacturing sectors in South Africa, though in four of the estimated specifications the measure of exposure to international competitive forces proves to be statistically insignificant. ${ }^{57}$ Parameter stability across the estimated specifications is less dramatic than in Fedderke (2005), but the range of parameter values spans a narrow range from 0.03 to 0.10 . The NX measure spans the range from -0.97 to 0.84 in the study sample. Thus an increase of 0.1 in the NX measure constitutes an increase of approximately $5 \%$ in the net export ratio within sample. For a parameter value of 0.05 , the implication is that output growth would improve by $0.5 \%$ per annum through the TFP channel due to the $5 \%$ improvement in the net export ratio, suggesting a fairly sensitive response to international exposure of the South African manufacturing sectors. Learning opportunities from exposure to international markets thus appear to be significant for South African manufacturing.

Fourth, increased concentration proves to lower TFP growth, regardless of whether the concentration measure is the GINI or the ROSEN. ${ }^{58}$ The impact of industry concentration is consistently negative, though for approximately half of the specifications it proves statistically insignificant. Where statistically significant, parameter values generally centre on approximately -0.3 . The within sample range of the GINI variable is from 0.69 to 0.99 , such that for the parameter value of -0.3 the implication of a reduction of the concentration measure of $0.1(1 / 3$ of the in-sample range of the GINI measure), would generate $3 \%$ more output growth per annum through the TFP channel.

These results closely mirror those already reported in Fedderke (2005). What is new in the present paper, are the results to emerge from the infrastructure measures.

In general, the estimated results differ sharply from those reported for the labor productivity specifications of the previous subsection.

The striking feature of the infrastructure coefficients is that they are almost uniformly negative suggesting a negative impact of virtually all forms of infrastructure on efficiency gains as measured

\footnotetext{
${ }^{55}$ There are three exceptions, higher coefficient estimates in the specifications controlling for lnGOODS and lnAPASS (columns 6 of Table 8A and column 16 of Table 8B), and a lower coefficient in the specification controlling for lnTRDS (column 10 of Table 8B).

${ }^{56}$ There are two exceptions: for the specifications controlling for locomotives and total roads in columns 4 of Table $8 \mathrm{~A}$ and 10 of Table $8 \mathrm{~B}$.

${ }^{57}$ In the specifications controlling for gross infrastructural capital formation (column 1 of Table 8A), railway passenger journeys (column 8 of Table 8B), passenger vehicles (column 12 of Table 8B), and ports (column 14 of Table $8 \mathrm{~B})$.

${ }^{58}$ We report only the GINI results. Rosen results are entirely symmetrical, and available from the authors on request.
} 
by TFP. The only exceptions to this are three infrastructure measures that prove insignificant statistically, coaching stock (column 5 of Table 8A), revenue earning freight (column 9 of Table 8A), and SAA flight passengers (column 15 of Table 8B), and three infrastructure measures which are the only measures which appear to have a positive impact on TFP growth. Goods rolling stock (column 6 of Table 8A), total roads (column 10 of Table 8B) and ports (column 14 of Table 8B).

None of the positive impacts is economically strong, with the highest elasticity reaching no more than 0.15. By contrast, the negative elasticities attaching to some of the alternative infrastructure measures, is considerably higher, notably the negative elasticity of -0.6 attaching to the railway network.

The evidence thus suggests that infrastructure is not a strong source of efficiency gains in the South African manufacturing sector as measured by TFP growth. This evidence stands in strong contrast to the pervasive and often economically powerful positive impact that infrastructure in South Africa appears to have had on manufacturing sector labor productivity.

One possible inference to draw from this evidence, is that the impact of infrastructure in South African manufacturing is directly on output per worker as a distinct factor of production - rather than indirect in fostering the productivity of private sector capital. A second possibility is that endogeneity is present as much for the idirect impact of infrastructure, as it is for the direct effect. We have already seen that accounting for potential endogeneity of infrastructure in the labor productivity estimations, strengthens the impact of the infrastructure measures both statistically as well as in economic terms. We thus investigate the impact of infrastrucutre on the TFP measure under instrumental variables estimation.

\subsubsection{Results in the Presence of Instrumentation}

Estimation is now of equation (18) by means of the PMG panel estimator for South African manufacturing sectors, but with the infrastructure measure is now replaced by the instrumented measure. The instrumentation strategy is as outlined in section 5.1.2.

Results are reported in Tables 9A, 9B and 9C.

As before, results confirm adjustment to equilibrium (see the $E C M$-parameters, which correspond to the $\phi$-parameters of equation 8), and in general Hausman tests (denoted $h$-tests) confirm the legitimacy of the PMG estimator by failing to reject the homogeneity restriction on the long-run coefficients for South African manufacturing sectors.

As for the previous subsection, the finding for R\&D expenditure, for the skills ratio (SKRAT), and for industry concentration (GINI) are symmetrical to those already reported in the preceding subsection. Furthermore, in general the net export ratio confirms the positive impact on total factor productivity growth previously reported (though there are a number of exceptions to this finding that we discuss explicitly in the following discussion). We, therefore, move directly to the discussion of the infrastructural measures.

First, the aggregate economic infrastructure measures of flow (investment: lnGFCF) and stock (lnFCS), which both proved negative and significant under the estimation in the absence of instrumentation, now test positive and significant in the case of the flow measure, and statistically insignificant in the case of the stock measure. The implication is that a $1 \%$ increase in investment in economic infrastructure, raises TFP growth by 0.04 percentage points. Results are reported in columns (1) and (2) of Table 9A.

Second, the rail transport infrastructure measures which in the absence of instrumentation had proved to be negative and statistically significant, under instrumentation reverse their signs, and with the sole exception of total rail route kilometers (nRAIL), they all prove to be statistically significant. Nor is the economic magnitude of their impact small:

- In the case of the measures for locomotives (lnLOCO), goods stock (lnGOODS), and carrying capacity (lnCCAP), the implication is that a 1\% increase in the infrastructure stock would generate approximately 0.05 percentage points of productivity growth (as measured by TFP). 
For coaching stock, the return on a $1 \%$ increase in stock is slightly lower, at 0.03 percentage points of productivity growth.

- The impact of railway passenger journeys (RPASS) and revenue earning freight (RFRT) is stronger, with a $1 \%$ increase in the infrastructure stock generating approximately $0.16-0.18$ percentage points of productivity growth.

Full results for the rail transportation infrastructure measures are reported in columns (3) through (9) of Table 9A.

Third, for a number of additional measures of transport, communications, and power generation, the negative or insignificant impact reported in the absence of instrumentation is again rendered positive by instrumentation. Specifically:

- For the two transport measures given by the harbour tonnes of cargo handled (lnPORTS) and the number of airline passengers (lnAPASS) a 1\% increase in the infrastructure measure is associated with an increase of approximately 0.04 percentage points of productivity growth. See the results of column (14a) of Table 9B, and column (16) of Table 9C.

- For the measure of eletrical power generation (lnELEC), a $1 \%$ increase in the infrastructure measure is again associated with an increase of approximately 0.04 percentage points of productivity growth. See column (17a) of Table 9C.

- For the communications measure given by fixed telephone lines (lnFTEL), a 1\% increase in the infrastructure measure is associated with an increase of 0.07 percentage points of productivity growth. By contrast, total tleephone lines (fixed plus mobile: lnTEL), proves to be statistically insignificant. See columns (18a) and (19) of Table 9C.

A concern that attaches to this third set of results is that the net export measure reports a negative and statistically significant impact on productivity growth for the estimation incorporating the ports, the electricity generation and the fixed telephone line infrastructure measures.

One possible reason for the finding on the net export measure is that the positive impact of the net export measure might emerges only where export activity is supported by a sufficient level of supporting infrastructural services. Under this hypothesis, the positive impact of technology transfers associated with entry into international markets would only be realized where ports infrastructure, or communications facilities, are sufficiently developed, for instance. To test for the presence of such theshold effects in the impact of the infrastructure measures, we estimate the instrumented version of equation (18) under inclusion of interaction terms between the infrastructure and net exports ratio terms. For the sake of generality, we extend this approach to the additional air transport infrastructure measure specific to the domestic air carrier (lnSAA), which returned a statistically insignificant coefficient under IV estimation - see column (15a) of Table 9C.

Results from the specifications incorporating interaction terms are mixed. For the ports measure - column (14b) of Table 9B - and the measure for the passengers carried by the domestic carrier column (15b) of Table 9C -, the net impact of the net exports ratio is rendered positive, and the impact of the infrastructure variable remains positive and significant. Figures 3 and 4 report the net impacts of the net export and the infrastucture measures over the sample period of estimation. Note that the net impact particularly of the measure for the domestic carrier implies a strong economic impact: with a $1 \%$ increase in the infrastructure measure associated with an increase of 0.41 percentage points of productivity growth.

For the electricity and the telephone lines measures, however, results are less coherent. While the net impact of the net export ratio is now rendered positive, the net impact of the two infrastructure measures is negative under estimations incorporating the threshold effects - see columns (17b) and (18b) of Table 9C. 
Finally, the performance of the roads transportation infrastructure measures improves considerably over the estimations that do not employ IV's. The measure for the total roads network returns a very strong, positive, and statistically significant impact on productivity growth, with a $1 \%$ increase in the road network associated with a 2.8 percentage point increase in productivity growth - see column (10) of Table 9B.

Instrumentation does not reverse the negative and statistically significant coefficient on paved raods, however. Since the current study is concerned with manufactruing industry productivity growth, and since South African manufacturing industry is strongly concentrated in four metropolitan areas, ${ }^{59}$ we consider the total paved road distance between these four centres recommended as the best travel route by the South African Automobile Association. Table 10 provides summary evidence. What emerges is that the toal route distance between the metropolitan centres steadily declined over the last thirty years of the twentieth century due to extensive road improvement programmes, which straightend and hence shortened road distances between the manufacturing centres, as well as increased the number of lanes on South Africa's major manufacturing transport routes. The implication for our purposes is straightforward: more road infrastructure does not necessarily take the form of more road kilometers - indeed, on occasion the better infrastructure may take the form of fewer road kilometers. Employing the revised roads infrastructure measure, incorporating only the total road distance between the major metropolitan centres, the impact of paved roads on manufacturing sector productivity growth as measured by TFP becomes very strong indeed: with a $1 \%$ increase in the road network associated with a 4.9 percentage point increase in productivity growth - as reported in column (11b) of Table 9B.

The concern with these findings is that the impact of the roads infrastrucutre is now so strong, as to be potentially implausible. However, as pointed out in Fedderke, Perkins and Luiz (2006), a 1\% increase in the stock of roads amounts to approximately $2000 \mathrm{~km}$ (computed as a $1 \%$ increase at the mean of the in-sample road stock), and assuming an average cost of $1 \mathrm{~km}$ of road of approximately R5.4 million in 1995 prices, the implied investment cost of R10 753 million amounts to a very substantial increase in public expenditure. Under these circumstances the implied growth impact of increases in the road infrastructure is not implausible. The findings of the present study are thus consistent with the aggregate economy-wide results of the earlier study.

The two final measures of road infrastructure given by passenger vehicles (lnVEHP) and goods vehicles (lnGOODS) continue to be statistically significantly negative even under IV estimation columns (12a) and (13a) of Table 9B. While in the case of passenger vehicles the impact of the infrasructure measure can be rendered negative through the inclusion of an interaction term with net exports - column $(12 \mathrm{~b})$ of Table 9B - this is not the case with the goods vehicle measure coulumns (13b, 13c) of Table 9B.

Nevertheless, under instrumentation panel estimation for South Africa's manufacturing sector reverses the initially persistent negative TFP growth impacts, where the infrastructure measures were not instrumented. By contrast, controlling for the possibility of endogeneity in the infrastructure measures renders the impact of infrastructure capital not only positive, but of economically meaningful magnitudes. Figure 5 summarizes the two sets of findings. We exclude the total and paved roads measures, given the relative strength of their impacts.

\section{Conclusion}

Empirical explorations of the growth and productivity impacts of infrastructure have been characterized by ambiguous (countervailing signs) results with little robustness. A number of explanations of the contradictory findings have been proposed. These range from the crowd-out of private by public sector investment, non-linearities generating the possibility of infrastructure over-provision,

\footnotetext{
${ }^{59}$ Gauteng around Johannesburg, Cape Town, Durban, and Port Elizabeth.
} 
simultaneity between infrastructure provision and growth, and the possibility of multiple (hence indirect) channels of influence between infrastructure and productivity improvements.

This paper explores these possibilities utilizing panel data for South Africa over the 1970-2000 period, and a range of 19 infrastructure measures. Utilizing a number of alternative measures of productivity, the prevalence of ambiguous (countervailing signs) results, with little systematic pattern is also shown to hold for our data set in estimations that include the infrastructure measures in simple growth frameworks.

We demonstrate, however, that controlling for potential endogeneity of infrastructure in estimation robustly eliminates virtually all evidence of possible overinvestment in infrastructure.

Indeed, controlling for the possibility of endogeneity in the infrastructure measures renders the impact of infrastructure capital not only positive, but of economically meaningful magnitudes.

These findings are invariant between the direct impact of infrastructure on labor productivity, and the indirect impact of infrastructure on total factor productivity. 


\section{References}

[1] Aghion, P. and Howitt, P., 1992, A Model of Growth through Creative Destruction, Econometrica, 60(2), 323-351.

[2] Akinbobola, T.O., and Saibu, M.O.O., 2004, Income Inequality, Unemployment and Poverty in Nigeria: A Vector Autoregressive Approach, Journal of Policy Reform, 7(3), 175-83.

[3] Arrow, K.J., 1962, The Economic implications of Learning by Doing, Review of Economic Studies, 29, 155-73.

[4] Aschauer, D.A. 1989a, Is public expenditure productive? Journal of Monetary Economics, $23(2), 177-200$.

[5] Aschauer, D.A. 1989b, Public Investment and Productivity Growth in the Group of Seven, Economic Perspectives, 13(5), 17-25.

[6] Aschauer, D.A. 1989c, Does Public capital Crowd Out Private Capital? Journal of Monetary Economics, 24(2): 171-88.

[7] Aschauer, D.A. 1998, The Role of Public Infrastructure Capital in Mexican Economic Growth, Economia Mexicana Nueva Epoca, 7(1), 47-78.

[8] Aschauer, D.A. 2001, Output and Employment Effects of Public Capital, Public Finance and Management, 1(2), 135-60.

[9] Ayogu, M.D., 1999, before Prebendalism: A Positive Analysis of Core Infrastructure Investment in a Developing Fiscal Federalism, African Development Review, 11(2), 169-98.

[10] Badawi, A., 2003, Private Capital Formation and Public Investment in Sudan: Testing the Substitutability and Complementarity Hypotheses in a Growth Framework, Journal of International Development, 15(6), 783-99.

[11] Bajo-Rubio, O., and Diaz-Roldan, C., 2005, Optimal Endowment of Public Capital: An Empirical Analysis for the Spanish Regions, Regional Studies, 39(3), 297-304.

[12] Baltagi, H., and Pinnoi, N., 1995, Public Capital Stock and State Productivity Growth: Further Evidence from an Error Correction Model, Empirical Economics, 20, 351-59.

[13] Barro, R.J., 1990, Government Spending in a Simple Model of Endogenous Growth, Journal of Political Economy, 98(5), S103-S125.

[14] Barro, R.J., 1998, Notes on Growth Accounting, National Bureau of Economic Research Working Paper No. 6654.

[15] Bartelsman, E.J., and Doms, M., 2000, Understanding Productivity: Lessons from Longitudinal Microdata, Journal of Economic Literature, 38, 569-94.

[16] Benhabib, J., and Spiegel, M.M., 1994, The Role of Human Capital in Economic Development: Evidence from Aggregate Cross-Country and Regional US Data, Journal of Monetary Economics, 32(3), 363-94.

[17] Bernard, A., and Jensen, J.B., 1995, Exporters, Jobs and Wages in US Manufacturing: 197687, Brookings Papers on Economic Activity: Microeconomics, Washington D.C., 67-112.

[18] Bernard, A., and Jensen, J.B., 1999, Exceptional Exporter Performance: Cause, Effect or Both?, Journal of International Economics, 47(1-), 1-25. 
[19] Bogetić, Ž., and Sanogo, I., 2005, Infrastructure, Productivity and Urban Dynamics in Côte d'Ivoire, World Bank Africa Region Working Paper Series No. 86, June 2005.

[20] Bogetić, Ž., and Fedderke,, J.W., 2006a, International Benchmarking of South Africa's Infrastructure Performance, Journal of Development Perspectives, 1(2), forthcoming, World Bank Policy Research Working Paper No. 3830.

[21] Bogetić, Ž., and Fedderke, J.W., 2006b, Forecasting Infrastructure Investment Needs: South Africa's Electricity and Telecom, South African Journal of Economics, forthcoming, World Bank Policy Research Working Paper No. 3829.

[22] Bonaglia, F., La Ferrara, E., and Marcellino, M., 2000, Public Capital and Economic Performance: Evidence from Italy, Giornale degli Economisti e Annali di Economia, 59(2), 221-44.

[23] Bosworth, B., and Collins, S.M., 2003, The Empirics of Growth: An Update, Brookings Papers on Economic Activity, Vol 2003 No 2, 113-206.

[24] Brox, J.A., and Fader, C.A., 2005, Infrastructure Investment and Canadian Manufacturing Productivity, Applied Economics, 37(11), 1247-56.

[25] Clerides, S., Lach, S., and Tybout, J.R., 1998, In Learning by Exporting Important? Micro Dynamic Evidence from Colombia, Mexico and Morocco, Quarterly Journal of Economics, 113(3), 903-47.

[26] Calderón, C., and Chong, A., 2004, Volume and Quality of Infrastructure and the Distribution of Income: An Empirical Investigation, Review of Income and Wealth, 50, 87-105.

[27] Calderón, C., and Servén, L., 2003, The Output Cost of Latin America's Infrastructure Gap, in W.Easterly and L.Servén, (eds.) The Limits of Stabilization: Infrastructure, Public Deficits, and Growth in Latin America, Stanford University Press and the World Bank, 119-38.

[28] Calderón, C., and Servén, L., 2005, The Effects of Infrastrucutre Development on Growth and Income Distribution, Mimeo, WPS3400.

[29] Cashin, P., 1995, Government Spending, Taxes, and Economic Growth, IMF Staff Papers, 42(2), 237-69.

[30] Canning, D., 1999, The Contribution of Infrastructure to Aggregate Output, World Bank Policy Research Working Paper No. 2246.

[31] Canning, D., and Pedroni, 2004, The Effect of Infrastructure on Long Run Economic Growth, mimeo: Harvard University, November 2004.

[32] Chatterjee, S., Sakoulis, G., and Turnovsky, S.J., 2003, Unilateral capital transfers, public investment and economic growth, European Economic Review, 47(6), 1077-1103.

[33] Charlot, S., Piguet, V., and Schmitt, B., 2003, Public Capital and Productivity: Which Effects on Regional Inequalities? Revue d'Economie Politique, 113(6), 851-80.

[34] Coe, D.T., and Helpman, E., 1995, International R\&D spillovers, European Economic Review, 39, 859-87.

[35] Coe, D.T., Helpman, E., and Hoffmaister, A.T., 1997, North-South R\&D Spillovers, Economic Journal, 107, 134-49.

[36] Delorme, C.D., Thompson, H.G., and Warren, R.S., 1999, Public Infrastructure and Private Productivity: A Stochastic Frontier Approach, Journal of Macroeconomics, 21(3), 563-76. 
[37] De Mello, L., 1997, Foreign Direct Investment in Developing Countries and Growth: A Selective Survey, Journal of Development Studies, 34(1), 1-34.

[38] Denison, E.F., 1962, Sources of Growth in the United States and the Alternatives Before Us, Supplement Paper 13, New York, Committee for Economic Development.

[39] Denison, E.F., 1967, Why Growth Rates Differ, Washington D.C.: The Brookings Institution.

[40] Denison, E.F., 1974, Accounting for United States Economic Growth, Washington D.C.: The Brookings Institution.

[41] Department of Transport, 1999, Moving South Africa.

[42] Dessus, S., and Herrera, R., 1999, Public Capital and Growth: An Econometric Study on Panel Data, Revue Economique, 50(1), 113-26.

[43] Destefanis, S., and Sena, V., 2005, Public Capital and Total Factor Productivity: New Evidence from the Italian Regions, Regional Studies, 39(5), 603-17.

[44] Demetriades, P.O., and Mamuneas, T.P., 2000, Intertemporal Output and Employment Effects of Public Infrasructure Capital: Evidence from12 OECD Economies, Economic Journal, 110(465), 687-712.

[45] Devarajan, S., Xie, D., and Zou, H., 1998, Should Public Capital be Subsidized or Provided? Journal of Monetary Economics, 41(2), 319-31.

[46] Doms, M.E., Dunne, T., and Troske, K., 1997, Workers, Wages and Technology, Quarterly Journal of Economics, 112(1), 253-90.

[47] Doms, M.E., and Jensen, J.B., 1998, Comparing Wages, Skills and Productivity Between Domestic and Foreign Owned Manufacturing Establishments in the United States, in R.Baldwin, R.Lipsey, and J.Richardson (eds.), Geography and Ownership as Bases for Economic Accounting, Chicago: University of Chicago Press.

[48] Easterly, W and Rebelo, S., 1993. Fiscal policy and economic growth, Journal of Monetary Economics, 32, 417-458.

[49] Easterly, W. and Servén, L., 2002, The Limits of Stabilization: Infrastructure, Public Deficits and Growth in Latin America, Stanford University Press and the World Bank.

[50] Entorf, H., and Kramarz, F., 1998, New Technologies, Wages and Worker Selection, Economics of Innovation and New Technology, 5(2-4), 165-97.

[51] Esfahani, H.S., and Ramirez, M.T., 2003, Institutions, infrastructure and economic growth, Journal of Development Economics, 70, 443-477.

[52] Estache, A., 2005, What Do We Know About Sub-Saharan Africa's Infrastructure and the Impact of the 1990s Reforms?, Mimeo, World Bank, Washington DC.

[53] Estache, A. Foster, V., and Wodon, Q., 2002, Accounting for Poverty in Infrastructure Reform: Learning from Latin America's Experience, WBI Development Studies, Washington DC: The World Bank.

[54] Estache, A. and Goicoechea, A., 2005,.A 'Research' Database on Infrastructure Economic Performance, Policy Research Paper No. 3643, The World Bank, Infrastructure Network, Office of the Vice President (June), Washington, D.C. 
[55] Everaert, G., 2003, Balanced Growth and Public Capital: An Empirical Analysis with I(2) Trends in Capital Stock, Economic Modelling, 20(4), 741-63.

[56] Everaert, G., and Heylen F., 2001, Public Capital and Productivity Growth: Evidence for Belgium, 1953-1996, Economic Modelling, 18(1), 97-116.

[57] Fagerberg, J., 1994, Technology and International Differences in Growth Rates, Journal of Economic Literature, 32(3), 1147-75.

[58] Fay, M., 2001,Financing the Future: Infrastructure Needs in Latin America, 2000-05, Policy Research Working Paper No. 2545, World Bank, Washington D.C.

[59] Fay, M., and Yepes, T., 2003, Investing in Infrastructure: What is Needed from 2000 to 2010, Policy Research Working Paper No. 3102, World Bank, Washington D.C.

[60] Fedderke, J.W., 2002, The Contribution of Growth in Total Factor Productivity to Growth in South Africa: 1970-97, South African Journal of Economics, 70(4), 611-46.

[61] Fedderke, J.W., 2005, Technology, Human Capital and Growth, Keynote Address: G20 Meeting August 2005, Pretoria South Africa.

[62] Fedderke, J.W., de Kadt, R, and Luiz, J.M., 2000, Uneducating South Africa: The Failure to address the 1910-1993 legacy, International Review of Education, 46 (3/4), 257-81.

[63] Fedderke, J.W., de Kadt R., and Luiz, J.M., 2001, Indicators of Political Liberty, Property Rights and Political Instability in South Africa: 1935-97, International Review of Law and Economics, 21, 103-34.

[64] Fedderke, J.W., de Kadt R., Luiz, J.M., 2003, A Capstone Tertiary Educational System: Inefficiency, Duplication and Inequity in South Africa's Tertiary Education System, 1910-93, Cambridge Journal of Economics, 27(3), 377-400.

[65] Fedderke, J.W., and Luiz, J.M., 2002, Production of Educational Output: time series evidence from socioeconomically heterogeneous populations - the case of South Africa, 1910-93, Economic Development and Cultural Change, 51(1), 161-88.

[66] Fedderke, J.W., Perkins, P., and Luiz, J.M., 2005, Infrastructural Investment in Long-run Economic Growth: South Africa 1875-2001, World Development, forthcoming.

[67] Fedderke, J.W., and Romm, A.T., 2006, Growth Impact and Determinants of Foreign Direct Investment into South Africa, 1956-2003, forthcoming Economic Modelling.

[68] Fedderke J.W. and Szalontai, G., 2005, Industry Concentration in South African Manufacturing: Trends \& Consequences, 1970-1996. forthcoming South African Journal of Economics.

[69] Fernald, J.G., 1999, Roads to Prosperity? Assessing the Link between Public Capital and Productivity, American Economic Review, 89(3), 619-38.

[70] Fernandez, M., and Montuenga-Gomez, V.M., 2003, The Effects of Public Capital on the Growth of Spanish Productivity, Contemporary Economic Policy, 21(3), 383-93.

[71] Fernandez, M., and Polo, C., 2002, Public Capital Productivity in the Presence of Technological and Human Capital, Revista de Economia Aplicada, 10(29), 151-61.

[72] Freeman, R., and Medoff, J., 1981, The impact of the percentage organized on union and nonunion wages, The Review of Economics and Statistics, 63(4), 561-72. 
[73] Frutos, R.F., Gracia-Diez M., and Perez-Amaral, T., 1998, Public Capital Stock and Economic Growth: An Analysis of the Spanish Economy, Applied Economics, 30(8), 985-94.

[74] Fuentes Flores, N.A., and Medoza Cota, J.E., 2003, Public Infrastructure and Regional Convergence in Mexico, Comercio Exterior, 53(2), 178-87.

[75] Ghafoor, A., and Yorucu, V., 2002, Public Expenditure and Productivity Puzzle: The Case of Northern Cyprus, Middle East Technical University Studies in Development, 29(1-2), 69-85.

[76] Ghosh, S., and Roy, U., 2002, Optimal Growth with Public Capital and Public Services, Economics of Planning, 35(2), 271-92.

[77] Gong, L., 2003, Fiscal Federalism, Public Capital Formation, and Endogenous growth, Annals of Economics and Finance, 4(2), 471-90.

[78] Gramlich, E.M., 1994, Infrastructure Investment: A Review Essay, Journal of Economic Literature, $32(3), 1176-96$.

[79] Griliches, Z., 1979, Issues in Assessing the Contribution of Research and Development to Productivity Growth, Bell Journal of Economics, 10(1), 92-116.

[80] Grossman, G.M., and Helpman, E., 1991, Innovation and Growth in the Global Economy, Cambridge M.A.: MIT Press.

[81] Hall, B., and Mairesse, J., 1995, Exploring the Relationship between R\&D and Productivity in French Manufacturing Firms, Journal of Econometrics, 65(1), 263-93.

[82] Hakfoort, J., 1996, Public Capital, Private Sector Productivity and Economic Growth: A Macroeconomic Perspective, in Batten, D.F., and Karlsson, C., (eds.), Infrastructure and the Complexity of Economic Development, Berlin: Springer Verlag.

[83] Haskel, J., 1991, Imperfect competition, work practices and productivity growth, Oxford Bulletin of Economics and Statistics, 53(3), 265-80.

[84] Haskel, J., and Slaughter, M.J., 2001, Trade, Technology and UK Wage Inequality, Economic Journal, 111, 163-87.

[85] Haughwout, A.F., 2002, Public Infrastructure Investments, Productivity and Welfare in Fixed Geographic Areas, Journal of Public Economics, 83(3), 405-28.

[86] Hausman, J.A., 1978, Specification tests in economics, Econometrica, 46, 1251-70.

[87] Hausmann, R., Rodrik, D., and Velasco, A., 2005, Growth Diagnostics, Mimeo: Harvard University.

[88] Herrera, R., 1997, Productivity and Externalities of Public Expenditure: An Econometric Study of Time Series for India and Pakistan, Economie et Prevision, 0(131), 145-53.

[89] Ho, W., and Wang, Y., 2005, Public cpaital, Asymmetric Information and Economic Growth, Canadian Journal of Economics, 38(1), 57-80.

[90] Holtz-Eakin, D., 1994, Public Sector Capital and the Productivity Puzzle, Review of Economics and Statistics, 76, 12-21.

[91] Hopenhayn, H.A., and Rogerson, R., 1993, Job Turnover and Policy Evaluation: A General Equilibrium Analysis, Journal of Political Economy, 101(5), 915-38. 
[92] Hulten, C.R., 2001, Total Factor Productivity: A Short Biography, in C.R. Hulten, E.R. Dean and M. Harper, (eds), New Developments in Productivity Analysis, Studies in Income and Wealth Vol 63, Chicago: University Press, 1-54.

[93] Hurlin, C., 1999, The Contribution fo Public Capital to Private Factor Productivity: An Estimate using Sector-Based Panel Data for Ten OECD Countries, Economie et Prevision, 0(137), 49-65.

[94] Johansen, S., 1991, Estimation and Hypothesis Testing of Cointegration Vectors in Gaussian Vector Autoregressive Models, Econometrica, 59(6), 1551-80

[95] Johansen, S., and Juselius, K., 1990, Maximum Likelyhood Estimation and Inference on Cointegration - with applications to the demand for money, Oxford Bulletin of Economics and Statistics, 52(2), 169-210.

[96] Johansen, S., and Juselius, K., 1992, Testing structural hypotheses in a multivariate cointegrating analysis of the PPP and the UIP for UK, Journal of Econometrics, 53, 211-44.

[97] Jorgenson, D.W., and Griliches, Z., 1967, The Explanation of Productivity Change, Review of Economic Studies, 34, 249-80.

[98] Jorgenson, D.W., Griliches, Z., and Fraumeni, B.M., 1987, Productivity and U.S. Economic Growth, Cambridge M.A.: Harvard University Press.

[99] Jovanovic, B., 1982, Selection and Evolution in Industry, Econometrica, 50(3), 25-43.

[100] Kalaitzidakis, P., and Kalyvitis, S., 2004, On the macroeconomic implications of maintenance in public capital, Journal of Public Economics, 88(3/4), 695-712.

[101] Kalyvitis, S., 2003, Public Investment Rules and Endogenous Growth with Empirical Evidence from Canada, Scottish Journal of Political Economy, 50(1), 90-110.

[102] Keller, W., 1998, Are international R\&D spillovers trade-related? Analyzing spillovers among randomly matched trade partners, European Economic Review, 42, 1469-91.

[103] Kemmerling, A., and Stephan, A., 2002, The Contribution of Local Public Infrastructure to Private Productivity and its Political Economy: Evidence from a Panel of Large German Cities, Public Choice, 113(3-4), 403-24.

[104] Kessides, C., 1993, The contributions of infrastructure to economic development, World Bank Discussion Papers No. 213, World Bank, Washington D.C.

[105] Kessides, I., 2004, Reforming Infrastructure: Privatization, Regulation and Competition, World Bank and Oxford University Press.

[106] Krichel, T., and Levine, P., 2001, Does Precommitment Raise Growth? The Dynamics of Growth and Fiscal Policy, Scandinavian Journal of Economics, 103(2), 295-316.

[107] Lachler, U., and Aschauer, D.A., 1998, Public Investment and Econoic Growth in Mexico, World Bank Policy Research Working Paper Series No. 1964.

[108] Leipziger, D., 2001,.The Unfinished Agenda: Why is Latin America Lagging Behind? Finance 86 Development, International Monetary Fund, vol. 38, 38-41.

[109] Leipziger, Danny., Fay, Marianne., Wodon, Quentin. and Yepes, T., 2003, Achieving the Millenium Development Goals: The Role of Infrastructure, Policy Research Working Paper No. 3163, World Bank, Washington DC. 
[110] Lichtenberg, F.R., 1992, Corporate Takeovers and Productivity, Cambridge: MIT Press.

[111] Lichtenberg, F.R., and Siegel, D., 1991, The Impact of R\&D Investment on Productivity New Evidence Using Linked R\&D - LRD Data, Economic Enquiry, 29(2), 203-29.

[112] Lobo, J., and Rantisi, N.M., 1999, Investment in Infrastructure as Determinants of Metropolitan Productivity, Growth and Change, 30(1), 106-2\%.

[113] Lucas, R.E., 1988, On the Mechanics of Development Planning, Journal of Monetary Economics, 22(1), 3-42.

[114] Makin, T., and Paul, S., 2003, The Productive Effects of Public Infrastructure: What Do the Data Say? International Journal of Appplied Business and Economic Research, 1(2), 137-47.

[115] Mayer, J., 2001, Technology Diffusion, Human Capital and Economic Growth in Developing Countries, United Nations Conference on Trade and Development Discussion Paper, No. 154.

[116] McGuckin, R.H., and Sang, V.N., 1995, On Productivity and Plant Ownership Change: New Evidence from the LRD", RAND Journal of Economics, 26(2), 257-76.

[117] Miller, N.J., and Tsoukis, C., 2001, On the Optimality of Public Capital for Long-Run Economic Growth: Evidence from Panel Data, Applied Economics, 33(9), 1117-29.

[118] Mitra, A, Varoudakis, A and Véganzonès-Varoudkis, M. 2002., Productivity and technical efficiency in Indian states' manufacturing: the role of infrastructure, Economic Development and Cultural Change, 2002: 395-426.

[119] Mourmouras, A., and Tijerina, J.A., 1997, Government Investments in Schooling and Infrastructure: Ramsey vs. Public Choice Paths in a Lifecycle Model, Estudios Economicos, $12(1), 3-21$.

[120] Munnell, AH., 1990a, Why has productivity growth declined? Productivity and public investment, New England Economic Review, January/February 1990: 3-22.

[121] Munnell, AH., 1990b, How does public infrastructure affect regional economic performance? New England Economic Review, September/October 1990: 11-32.

[122] Munnell, AH., 1992, Infrastructure investment and economic growth, Journal of Economic Perspectives, 6(4): 189-198.

[123] National Integrated Resource Plan, 2004, National Integrated Resource Plan 2 2003/2004, National Electricity Regulator.

[124] Nelson, R.R., and Wright, G., 1992, The Rise and Fall of American Technological Leadership: The postwar era in historical perspective, Journal of Economic Literature, 30, 1931-64.

[125] Nickell, S., 1996, Competition and Corporate Performance, Journal of Political Economy, 104(4), 724-46.

[126] Nourzad, F., 2000, The Productivity Effect of Government Capital in Developing and Industrialized Countries, Applied Economics, 32(9), 1181-87.

[127] Nourzad, F., 2001, Public Sector Capital and Technical Efficiency in Private Sector Production, Konjunkturpolitik, 47(1), 39-50.

[128] Olley, G.S., and Pakes, A., 1996, The Dynamics of Productivity in the Telecommunications Industry, Econometrica, 64(6), 1263-97. 
[129] Pakes, A., and McGuire, P., 1994, Computing Markov-Perfect Nash Equilibria: Numerical Implications of a Dynamic Differentiated Product Model, RAND Journal of Economics, 25(4), $555-89$.

[130] Paul, S., 2003, Effects of Public Infrastructure on Cost Structure and Productivity in the Private Sector, Economic Record, 79(247), 446-61.

[131] Paul, S., Sahni, B.S., and Biswal, B.P., 2004, Public Infrastructure and the Productive Performance of Canadian Manufacturing Industries, Southern Economic Journal, 70(4), 998-1011.

[132] Pereira, A.M., and Sagales, O.R., 1999, Public Capital Formation and Regional Development in Spain, Review of Development Economics, 3(3), 281-94.

[133] Perkins, P., Fedderke, J.W., and Luiz, J.M., 2005, An Analysis of Economic Infrastructure Investment in South Africa, South African Journal of Economics, 73(2), 211-28.

[134] Pesaran, M.H., and Smith, R.P., (1995), Estimating Long-Run Relationships from Dynamic Heterogeneous Panels, Journal of Econometrics, 68,79-113.

[135] Pesaran M.H., Y. Shin and R.P. Smith (1999): Pooled Mean Group Estimation of Dynamic Heterogenous Panels, Journal of the American Statistical Association, 94, pp. 621-634.

[136] Petraglia, C., 2002, Total Factor Productivity Growth and Public Capital: The Case of Italy, Studi Economici, 57(78), 65-92.

[137] Rajan, R.G., and Subramanian, A., 2005, What Undermines Aid's Impact on Economic Growth? IMF Working Paper, WP/05/126.

[138] Ramirez, M, 2000a, Foreign Direct Investment in Mexico: A Cointegration Analysis, Journal of Development Studies, 37(1), 138-162.

[139] Ramirez, M, 2000b, Public Capital Formation and Labor Productivity Growth in Chile, Contemporary Economic Policy, 18(2), 159-69.

[140] Ramirez, M.D., 2002, Public Capital Formation and labor Productivity Growth in Mexico, Atlantic Economic Journal, 30(4), 366-79.

[141] Randolph, S., Bogetić, Ž., and Hefley, D., 1996, Determinants of Public Expenditure on Infrastructure: Transport and Communication, World Bank Policy Research Working Paper No. 1661, .

[142] Reinikka, R., and Svensson, J., 1999, How Inadequate Provision of Public Infrastructure and Services Affects Private Investment, World Bank Policy Research Working Paper No. 2262.

[143] Reinikka, R., and Svensson, J., 2002, Coping with poor public capital, Journal of Development Economics, 69(1), 51-69.

[144] Reynolds, T, 2005, Global developments in Telecommunications Pricing, OECD Presentation 14-15 July, Midrand, South Africa.

[145] Rivera-Batiz, L.A., and Romer, P., 1991, Economic integration and economic growth, Quarterly Journal of Economics, 106, 531-56.

[146] Röller, L-H., and Waverman, L., 2001, Telecommunications Infrastructure and Economic Development: A Simultaneous Approach, American Economic Review, 91(4), 909-23. 
[147] Rovolis, A., and Spence, N., 2002, Duality theory and cost function analysis in a regional context: the impact of public infrastructure capital in the Greek regions, Annals of Regional Science, 36(1), 55-78.

[148] Romer, P.M., 1986, Increasing Returns and Long-Run Growth, Journal of Political Economy, 94(5), 1002-37.

[149] Sachs,J. and Warner,A. 1997, Sources of Slow Growth in African Economies. Journal of African Economies. 6(3), 335-376.

[150] Sala-i-Martin, X., Doppelhofer, G., and Miller, R.I., 2004, Determinants of Long-Term Growth: A Bayesian Averaging of Classical Estimates (BACE) Approach, American Economic Review, 94(4), 813-35.

[151] Salinas Jimenez, M.M., 2003, Efficiency and TFP Growth in the Spanish Regions: the Role of Human and Public Capital, Growth and Change, 34(2), 157-74.

[152] Sanchez-Robles, B., 1998a, The Role of Infrastructure Investment in Development: Some Macroeconomic Considerations, International Journal of Transport Economics, 25(2), 113-36.

[153] Sanchez-Robles, B., 1998b, Infrastructure Investment and Growth: Some Empirical Evidence, Contemporary Economic Policy, 16(1), 98-108.

[154] Seung, C.K., and Kraybill, D.S., 2001, The Effects of Infrastructure Investment: A Two-Sector Dynamic Computable General Equilibrium Analysis for Ohio, International Regional Science Review, 24(2), 261-81.

[155] Shioji, E., 2001, Public Capital and Economic Growth: A Convergence Approach, Journal of Economic Growth, 6(3), 205-27.

[156] Shirley, C., and Winston, C., 2004, Firm Inventory Behaviour and the Returns from Highway Infrastructure Investments, Journal of Urban Economics, 55(2), 398-415.

[157] South African Reserve Bank Annual Economic Report. Various issues.

[158] Stephan, A., 2003, Assessing the Contribution of Public Capital to Private Production: Evidence from the German Manufactruing Sector, International review of Applied Economics, 17(4), 399-417.

[159] Thangavelu, S.M., and Owyong, D.T., 2000, Impact of Public Capital on the Manufacturing Productive Performance fo Japanese Industries, Applied Economics, 32(12), 1515-20.

[160] Tybout, J.R., 2000, Manufacturing Firms in Developing Countries: How Well Do They Do and Why?, Journal of Economic Literature, 38, 11-44.

[161] UNDP/World Bank, 2005, Power Sector Performance in Africa: Assessing Impact on Poor People, ESMAP Report 306/05, August.

[162] Wickens, M.R., 1996, Interpreting cointegrating vectors and common stochastic trends, Journal of Econometrics, 74, 255-71.

[163] World Bank. 1994. World Development Report 1994: infrastructure for development. New York: Oxford University Press.

[164] Yakita, A., 2004, Elasticity of Substitution in Public Capital Formation and Economic Growth, Journal of Macroeconomics, 26(3), 391-408. 


\begin{tabular}{ll}
\hline TABLE 1: Manufacturing Sectors of South Africa included in Panel \\
\hline Food & Plastics \\
Beverages & Glass \& Glass Products \\
Textiles \& Knitting & Other Non-metallic Minerals \\
Wearing Apparel & Basic Iron \& Steel \\
Leather \& Tanning & Basic Non-ferrous Metals \\
Footwear & Fabricated Metals \\
Wood & Machinery \& Apparatus \\
Paper & Electrical Machinery \\
Publishing \& Printing & Motor Vehicles \& Accessories \\
Basic Chemicals & Transport Equipment \\
Other Chemicals \& Fibres & Furniture \\
Rubber & Other Manufacturing \& Recycling \\
\hline
\end{tabular}

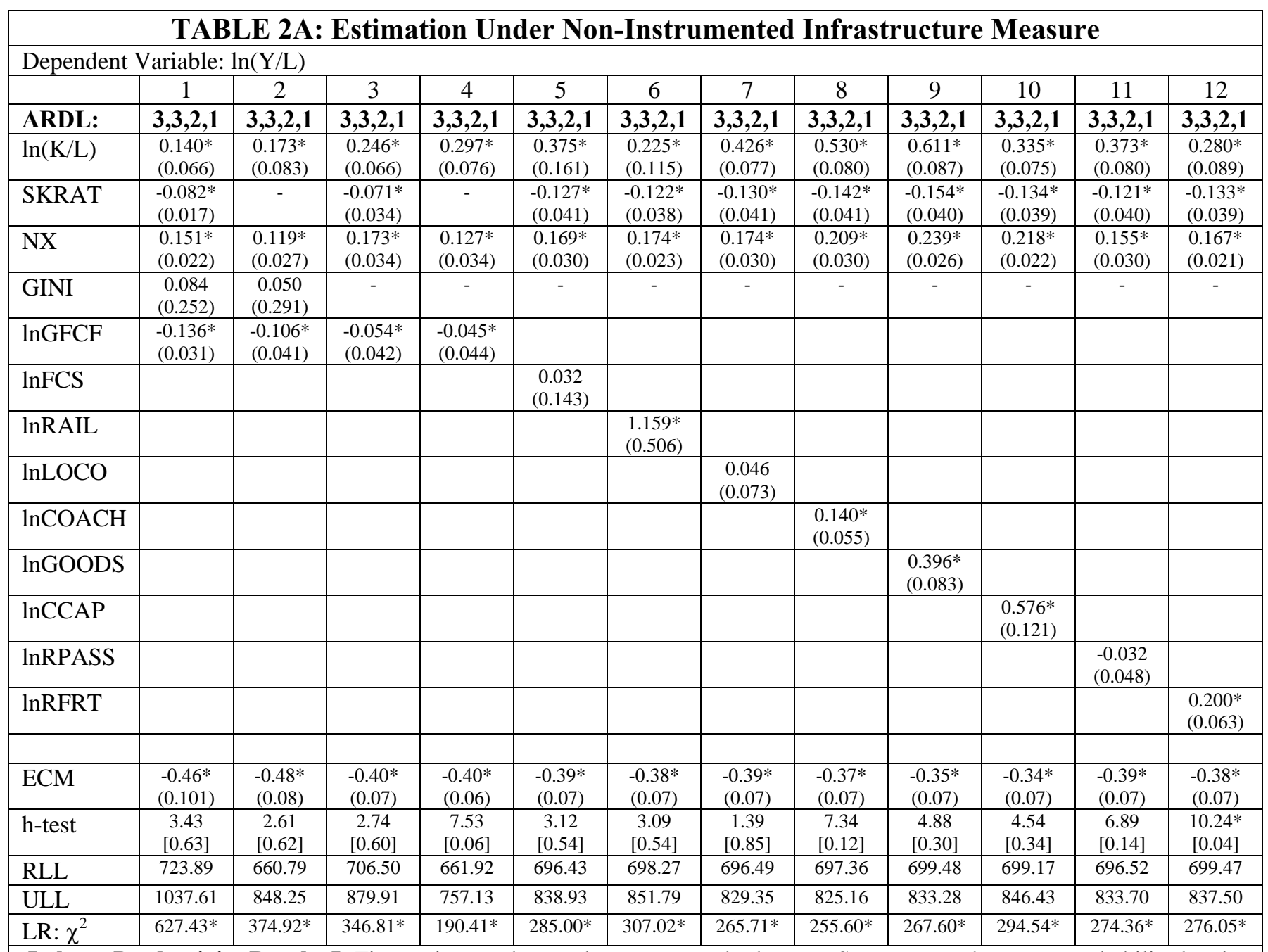

Labour Productivity Results I: Figures in round parentheses are standard errors. Square parentheses are probability levels. * denotes significance at the 5 percent level. 


\begin{tabular}{|c|c|c|c|c|c|c|c|c|c|c|}
\hline \multicolumn{11}{|c|}{ TABLE 2B: Estimation Under Non-Instrumented Infrastructure Measure } \\
\hline \multicolumn{11}{|c|}{ Dependent Variable: $\ln (\mathrm{Y} / \mathrm{L})$} \\
\hline & 13 & 14 & 15 & 16 & 17 & 18 & 19 & 20 & 21 & 22 \\
\hline ARDL: & $3,3,2,1$ & $3,3,2,1$ & $3,3,2,1$ & $3,3,2,1$ & $3,3,2,1$ & $3,3,2,1$ & $3,3,2,1$ & $3,3,2,1$ & $3,3,2,1$ & $3,3,2,1$ \\
\hline $\ln (\mathrm{K} / \mathrm{L})$ & $\begin{array}{l}0.418^{*} \\
(0.095)\end{array}$ & $\begin{array}{l}1.300^{*} \\
(0.540)\end{array}$ & $\begin{array}{l}1.160^{*} \\
(0.241)\end{array}$ & $\begin{array}{l}1.228^{*} \\
(0.344) \\
\end{array}$ & $\begin{array}{c}-0.037 \\
(0.157) \\
\end{array}$ & $\begin{array}{c}0.193^{* * *} \\
(0.113)\end{array}$ & $\begin{array}{c}0.285 \\
(0.119)\end{array}$ & $\begin{array}{l}1.334^{*} \\
(0.286) \\
\end{array}$ & $\begin{array}{l}0.727^{*} \\
(0.215) \\
\end{array}$ & $\begin{array}{c}0.556^{*} \\
(0.211) \\
\end{array}$ \\
\hline SKRAT & $\begin{array}{l}-0.126^{*} \\
(0.041)\end{array}$ & $\begin{array}{c}-0.130^{*} \\
(0.041)\end{array}$ & $\begin{array}{l}-0.121^{*} \\
(0.040)\end{array}$ & $\begin{array}{l}-0.116^{*} \\
(0.038)\end{array}$ & $\begin{array}{c}-0.132^{*} \\
(0.039)\end{array}$ & $\begin{array}{c}-0.132^{*} \\
(0.040)\end{array}$ & $\begin{array}{c}-0.122^{*} \\
(0.041)\end{array}$ & $\begin{array}{c}-0.121^{*} \\
(0.040)\end{array}$ & $\begin{array}{c}-0.142^{*} \\
(0.043)\end{array}$ & $\begin{array}{c}-0.132^{*} \\
(0.041)\end{array}$ \\
\hline NX & $\begin{array}{l}0.167^{*} \\
(0.026)\end{array}$ & $\begin{array}{l}0.183^{*} \\
(0.029)\end{array}$ & $\begin{array}{l}0.139 * \\
(0.025)\end{array}$ & $\begin{array}{l}0.158^{*} \\
(0.030)\end{array}$ & $\begin{array}{l}0.156^{*} \\
(0.022)\end{array}$ & $\begin{array}{l}0.184^{*} \\
(0.026)\end{array}$ & $\begin{array}{l}0.149 * \\
(0.030)\end{array}$ & $\begin{array}{l}0.145^{*} \\
(0.020)\end{array}$ & $\begin{array}{l}0.184^{*} \\
(0.028)\end{array}$ & $\begin{array}{l}0.174^{*} \\
(0.029)\end{array}$ \\
\hline GINI & - & - & - & - & - & - & - & - & - & - \\
\hline $\operatorname{lnTRDS}$ & $\begin{array}{c}-0.001 \\
(0.006)\end{array}$ & & & & & & & & & \\
\hline $\ln P R D S$ & & $\begin{array}{c}-1.087^{*} \\
(0.650)\end{array}$ & & & & & & & & \\
\hline lnVEHP & & & $\begin{array}{c}-0.552^{*} \\
(0.169)\end{array}$ & & & & & & & \\
\hline $\operatorname{lnVEHG}$ & & & & $\begin{array}{l}-0.571^{*} \\
(0.225)\end{array}$ & & & & & & \\
\hline lnPORTS & & & & & $\begin{array}{l}0.180^{*} \\
(0.052) \\
\end{array}$ & & & & & \\
\hline $\operatorname{lnSAA}$ & & & & & & $\begin{array}{c}0.286^{*} \\
(0.095)\end{array}$ & & & & \\
\hline lnAPASS & & & & & & & $\begin{array}{c}0.043 \\
(0.038)\end{array}$ & & & \\
\hline lnELEC & & & & & & & & $\begin{array}{c}-0.432^{*} \\
(0.138)\end{array}$ & & \\
\hline lnFTEL & & & & & & & & & $\begin{array}{c}-0.121 \\
(0.081)\end{array}$ & \\
\hline lnTEL & & & & & & & & & & $\begin{array}{c}-0.050 \\
(0.071)\end{array}$ \\
\hline ECM & $\begin{array}{l}-0.39 * \\
(0.07)\end{array}$ & $\begin{array}{l}-0.38^{*} \\
(0.06)\end{array}$ & $\begin{array}{l}-0.40^{*} \\
(0.060)\end{array}$ & $\begin{array}{c}-0.40^{*} \\
(0.06)\end{array}$ & $\begin{array}{l}-0.39 * \\
(0.07)\end{array}$ & $\begin{array}{c}-0.39 * \\
(0.06)\end{array}$ & $\begin{array}{l}-0.41^{*} \\
(0.07)\end{array}$ & $\begin{array}{l}-0.38^{*} \\
(0.06)\end{array}$ & $\begin{array}{l}-0.38^{*} \\
(0.07)\end{array}$ & $\begin{array}{c}-0.39 * \\
(0.07)\end{array}$ \\
\hline h-test & $\begin{array}{c}6.18 \\
{[0.19]}\end{array}$ & $\begin{array}{c}2.45 \\
{[0.65]}\end{array}$ & $\begin{array}{l}13.28^{*} \\
{[0.01]}\end{array}$ & $\begin{array}{c}2.76 \\
{[0.60]} \\
\end{array}$ & $\begin{array}{c}5.49 \\
{[0.24]} \\
\end{array}$ & $\begin{array}{c}2.13 \\
{[0.71]} \\
\end{array}$ & $\begin{array}{c}3.87 \\
{[0.42]} \\
\end{array}$ & $\begin{array}{c}3.25 \\
{[0.52]}\end{array}$ & $\begin{array}{l}17.25^{*} \\
{[0.00]}\end{array}$ & $\begin{array}{c}6.17 \\
{[0.19]} \\
\end{array}$ \\
\hline RLL & 2996.43 & 697.45 & 700.64 & 698.29 & 701.27 & 700.10 & 696.69 & 699.36 & 696.92 & 696.49 \\
\hline ULL & 814.48 & 823.79 & 843.87 & 848.31 & 836.13 & 816.80 & 855.10 & 832.24 & 846.53 & 823.84 \\
\hline LR: $\chi^{2}$ & $236.10^{*}$ & $252.67 *$ & $286.46^{*}$ & $300.03^{*}$ & 269.71* & $233.39 *$ & $316.82 *$ & $265.74^{*}$ & $299.24 *$ & $254.70^{*}$ \\
\hline
\end{tabular}




\begin{tabular}{|c|c|c|c|c|c|c|c|c|c|c|c|c|c|c|c|c|c|c|c|}
\hline \multirow{2}{*}{\multicolumn{20}{|c|}{ Instrumentation: Per Capita GDP: F1 }} \\
\hline & & & & & & & & & & & & & & & & & & & \\
\hline & GFCF & FCS & RAIL & LOCO & COACH & GOODS & CCAP & RPASS & RFRT & TRDS & PRDS & VEHP & VEHG & PORTS & SAA & APASS & TEL & FTEL & ELEC \\
\hline \multicolumn{20}{|c|}{ Actual Deviation: Fitted - Actual } \\
\hline 1960s & -2273 & 143793 & 314 & -237 & -2514 & 3830 & 1059809 & -87261724 & 21386384 & 23247 & 35931 & 3537682 & 1033151 & -276786961 & -2999078 & -709119 & -69921 & -947850 & 30772 \\
\hline 1970s & -2265 & 239767 & 2204 & -179 & -313 & -8558 & 1428063 & -4983207 & 136992045 & -5439 & 26563 & 6863653 & 2330040 & -564912037 & 5964234 & -500081 & 231056 & -2691152 & -475941 \\
\hline $1980 \mathrm{~s}$ & 125 & 136389 & 1327 & -475 & -774 & -11699 & 282679 & -35493528 & 116179716 & -8244 & 17378 & 6412460 & 2192729 & -660126578 & 6171673 & -639043 & -707010 & -3990411 & -622428 \\
\hline 1990s & 902 & -9801 & -267 & 176 & 162 & 10099 & -433078 & 19711793 & 25478922 & 7524 & 5487 & 3362994 & 992561 & -567398632 & -111681 & -3562786 & -4711709 & -5217804 & -434865 \\
\hline \multicolumn{20}{|c|}{ Percentage Deviation: Fitted - Actual } \\
\hline $1960 \mathrm{~s}$ & -19 & 107 & 2 & -7 & -37 & 3 & 31 & -22 & 27 & 13 & 148 & 298 & 400 & -1194 & -420 & -191 & -10 & -130 & 93 \\
\hline $1970 \mathrm{~s}$ & -9 & 91 & 11 & -4 & -3 & -5 & 28 & -1 & 115 & -3 & 67 & 324 & 359 & -1362 & 233 & -40 & 21 & -247 & -672 \\
\hline $1980 \mathrm{~s}$ & 1 & 34 & 6 & -10 & -7 & -7 & 4 & -5 & 70 & -5 & 35 & 193 & 202 & -742 & 145 & -39 & -33 & -186 & -463 \\
\hline $1990 \mathrm{~s}$ & 5 & -2 & -1 & 5 & 2 & 7 & -7 & 4 & 14 & 4 & 9 & 81 & 71 & -416 & -2 & -92 & -81 & -128 & -228 \\
\hline
\end{tabular}

\section{TABLE 4}

Instrumentation: Per Capita GDP, Output Share of Agriculture and Output Share of Manufacturing: F2

\begin{tabular}{|c|c|c|c|c|c|c|c|c|c|c|c|c|c|c|c|c|c|c|c|}
\hline \multicolumn{20}{|c|}{ Instrumentation: Per Capita GDP, Output Share of Agriculture and Output Share of Manufacturing: F2 } \\
\hline & GFCF & FCS & RAIL & LOCO & СОАСH & GOODS & CCAP & RPASS & RFRT & TRDS & PRDS & VEHP & VEHG & PORTS & SAA & APASS & TEL & FTEL & ELEC \\
\hline \multicolumn{20}{|c|}{ Actual Deviation: Fitted - Actual } \\
\hline 1960s & -182 & 86351 & 120 & 633 & 360 & 22099 & 1891863 & 1007065792 & -7402068 & 196 & 16264 & 4805833 & 377423 & -35057083 & -1707657 & 5894187 & 3299270 & 722982 & -5044 \\
\hline 1970s & -991 & 166206 & 1184 & 559 & 1626 & 12150 & 2263778 & 1114262905 & 41641199 & -987 & 11997 & 7679287 & 641019 & 55173232 & 2156695 & 2283025 & -3145182 & 3573403 & 81084 \\
\hline 1980s & 175 & 80338 & 704 & -415 & -1199 & -10760 & 603877 & 1041776468 & 10352684 & -1020 & 7645 & 8834304 & 467542 & 53055490 & 2019513 & 3104828 & 1895833 & 5516222 & 128120 \\
\hline 1990s & -265 & 1100 & -134 & -386 & -1808 & -28083 & -823029 & 1099334928 & 13520010 & -1136 & 2014 & 491740 & 331945 & 162027729 & 1330909 & 5348900 & -29955839 & 7108740 & 90175 \\
\hline \multicolumn{20}{|c|}{ Percentage Deviation: Fitted - Actual } \\
\hline $1960 \mathrm{~s}$ & -2 & 64 & 1 & 18 & 5 & 18 & 56 & 255 & -9 & 0 & 67 & 405 & 146 & -151 & -239 & 1586 & 452 & 99 & -15 \\
\hline 1970s & -4 & 63 & 6 & 13 & 18 & 7 & 44 & 188 & 35 & -1 & 30 & 362 & 99 & 133 & 84 & 181 & -288 & 328 & 115 \\
\hline 1980s & 1 & 20 & 3 & -9 & -11 & -6 & 9 & 155 & 6 & -1 & 15 & 266 & 43 & 60 & 47 & 191 & 88 & 257 & 95 \\
\hline 1990s & -2 & 0 & -1 & -11 & -25 & -21 & -13 & 233 & 8 & -1 & 3 & 12 & 24 & 119 & 27 & 138 & -516 & 174 & 47 \\
\hline
\end{tabular}




\begin{tabular}{|c|c|c|c|c|c|c|c|}
\hline \multicolumn{8}{|c|}{ TABLE 5A: Correlation between Variables and their Instruments } \\
\hline Variable & Instrument 1 & \multicolumn{2}{|c|}{ Instrument 2} & Variable & Instrument 1 & \multicolumn{2}{|c|}{ Instrument 2} \\
\hline GFCF & 0.85 & \multicolumn{2}{|c|}{$0.86^{*}$} & PRDS & 0.58 & \multicolumn{2}{|c|}{$0.97^{\star}$} \\
\hline FCS & 0.60 & \multicolumn{2}{|c|}{$0.81^{*}$} & VEHP & $0.46^{*}$ & \multicolumn{2}{|c|}{-0.07} \\
\hline RAIL & 0.47 & \multicolumn{2}{|c|}{$0.76^{*}$} & VEHG & 0.47 & \multicolumn{2}{|c|}{$0.93^{*}$} \\
\hline LOCO & $0.79 *$ & \multicolumn{2}{|c|}{0.49} & PORTS & -0.31 & \multicolumn{2}{|c|}{$0.93^{*}$} \\
\hline $\mathrm{COACH}$ & $0.78^{\star}$ & \multicolumn{2}{|c|}{0.60} & SAA & 0.59 & \multicolumn{2}{|c|}{$0.89 *$} \\
\hline GOODS & $0.88^{\star}$ & \multicolumn{2}{|c|}{0.65} & APASS & 0.12 & \multicolumn{2}{|c|}{$0.64^{*}$} \\
\hline CCAP & $0.73^{\star}$ & \multicolumn{2}{|c|}{0.35} & TEL & 0.10 & \multicolumn{2}{|c|}{$-0.80^{*}$} \\
\hline RPASS & $0.92^{*}$ & \multicolumn{2}{|c|}{0.90} & FTEL & -0.19 & \multicolumn{2}{|c|}{$0.91^{*}$} \\
\hline RFRT & 0.61 & \multicolumn{2}{|c|}{$0.88^{*}$} & ELEC & -0.38 & \multicolumn{2}{|c|}{$0.85^{\star}$} \\
\hline TRDS & 0.21 & \multicolumn{2}{|c|}{$0.55^{\star}$} & & & \\
\hline \multicolumn{8}{|c|}{${ }^{*}$ denotes the instrument with higher correlation with the original regressor. } \\
\hline \multicolumn{8}{|c|}{ TABLE 5B: Correlation between Variables and Dependent Variables } \\
\hline Variable & & YIL & TFP & Variable & & YIL & TFP \\
\hline \multirow[t]{2}{*}{ GFCF } & Instrument 1 & -0.048 & 0.049 & PRDS & Instrument 1 & -0.048 & 0.049 \\
\hline & Instrument 2 & -0.061 & 0.066 & & Instrument 2 & 0.087 & -0.074 \\
\hline \multirow[t]{2}{*}{ FCS } & Instrument 1 & -0.048 & 0.049 & VEHP & Instrument 1 & -0.048 & 0.049 \\
\hline & Instrument 2 & 0.006 & 0.017 & & Instrument 2 & -0.057 & -0.039 \\
\hline \multirow[t]{2}{*}{ RAIL } & Instrument 1 & -0.048 & 0.049 & VEHG & Instrument 1 & -0.048 & 0.049 \\
\hline & Instrument 2 & 0.027 & -0.083 & & Instrument 2 & 0.093 & -0.042 \\
\hline LOCO & Instrument 1 & -0.048 & 0.049 & PORTS & Instrument 1 & 0.048 & -0.049 \\
\hline & Instrument 2 & -0.076 & 0.102 & & Instrument 2 & 0.094 & -0.018 \\
\hline $\mathrm{COACH}$ & Instrument 1 & -0.048 & 0.049 & SAA & Instrument 1 & -0.048 & 0.049 \\
\hline & Instrument 2 & -0.074 & 0.102 & & Instrument 2 & 0.060 & 0.019 \\
\hline GOODS & Instrument 1 & -0.048 & 0.049 & APASS & Instrument 1 & 0.036 & -0.097 \\
\hline & Instrument 2 & -0.079 & 0.080 & & Instrument 2 & 0.065 & 0.052 \\
\hline CCAP & Instrument 1 & -0.048 & 0.049 & TEL & Instrument 1 & -0.048 & 0.049 \\
\hline & Instrument 2 & -0.071 & 0.081 & & Instrument 2 & -0.062 & -0.067 \\
\hline RPASS & Instrument 1 & -0.048 & 0.049 & FTEL & Instrument 1 & 0.048 & -0.049 \\
\hline & Instrument 2 & -0.055 & 0.097 & & Instrument 2 & 0.089 & -0.081 \\
\hline RFRT & Instrument 1 & -0.048 & 0.049 & ELEC & Instrument 1 & 0.048 & -0.049 \\
\hline & Instrument 2 & 0.071 & 0.075 & & Instrument 2 & 0.069 & -0.113 \\
\hline TRDS & Instrument 1 & 0.048 & -0.049 & & & & \\
\hline & Instrument 2 & -0.042 & 0.134 & & & & \\
\hline
\end{tabular}




\begin{tabular}{|c|c|c|c|c|c|c|c|c|c|}
\hline \multicolumn{10}{|c|}{ TABLE 6A: Estimation Under Instrumented Infrastructure Measure } \\
\hline \multicolumn{10}{|c|}{ Dependent Variable: $\ln (\mathrm{Y} / \mathrm{L})$} \\
\hline & 1 & 2 & 3 & 4 & 5 & 6 & 7 & 8 & 9 \\
\hline ARDL: & $3,1,1,1$ & $3,3,2,1$ & $\mathbf{3 , 3 , 2 , 1}$ & $\mathbf{3 , 3 , 2 , 3}$ & $3,3,2,3$ & $\mathbf{3 , 3 , 2 , 3}$ & $\mathbf{3 , 3 , 2 , 3}$ & $\mathbf{3 , 3 , 2 , 3}$ & $3,3,2,3$ \\
\hline $\ln (\mathrm{K} / \mathrm{L})$ & $\begin{array}{l}0.217^{*} \\
(0.080)\end{array}$ & $\begin{array}{l}0.409^{*} \\
(0.075) \\
\end{array}$ & $\begin{array}{l}0.389^{*} \\
(0.077) \\
\end{array}$ & $\begin{array}{l}0.963^{*} \\
(0.081) \\
\end{array}$ & $\begin{array}{l}0.920^{*} \\
(0.085)\end{array}$ & $\begin{array}{l}0.962^{*} \\
(0.081)\end{array}$ & $\begin{array}{l}0.950^{*} \\
(0.083)\end{array}$ & $\begin{array}{l}0.927^{*} \\
(0.085)\end{array}$ & $\begin{array}{r}0.899^{*} \\
(0.087)\end{array}$ \\
\hline SKRAT & $\begin{array}{l}-0.017 \\
(0.037)\end{array}$ & $\begin{array}{l}-0.138^{*} \\
(0.041)\end{array}$ & $\begin{array}{l}-0.132^{*} \\
(0.039)\end{array}$ & $\begin{array}{l}-0.188^{*} \\
(0.032)\end{array}$ & $\begin{array}{l}-0.188^{*} \\
(0.034)\end{array}$ & $\begin{array}{l}-0.188^{*} \\
(0.032)\end{array}$ & $\begin{array}{l}-0.189^{*} \\
(0.033)\end{array}$ & $\begin{array}{c}-0.189^{*} \\
(0.033)\end{array}$ & $\begin{array}{l}-0.188^{*} \\
(0.034)\end{array}$ \\
\hline NX & $\begin{array}{l}0.092^{*} \\
(0.042)\end{array}$ & $\begin{array}{l}0.195^{*} \\
(0.030)\end{array}$ & $\begin{array}{l}0.197^{*} \\
(0.030)\end{array}$ & $\begin{array}{l}0.161^{*} \\
(0.033)\end{array}$ & $\begin{array}{l}0.168^{*} \\
(0.035)\end{array}$ & $\begin{array}{l}0.161^{*} \\
(0.033)\end{array}$ & $\begin{array}{l}0.163^{*} \\
(0.034)\end{array}$ & $\begin{array}{l}0.167^{*} \\
(0.034)\end{array}$ & $\begin{array}{l}0.170^{*} \\
(0.030)\end{array}$ \\
\hline GINI & - & - & - & - & - & - & - & - & - \\
\hline lnGFCF F1 & $\begin{array}{l}0.196^{*} \\
(0.056)\end{array}$ & & & & & & & & \\
\hline lnFCS F2 & & $\begin{array}{l}0.189 * \\
(0.098)\end{array}$ & & & & & & & \\
\hline lnRAIL F2 & & & $\begin{array}{l}0.805^{*} \\
(0.435)\end{array}$ & & & & & & \\
\hline $\operatorname{lnLOCO~F1~}$ & & & & $\begin{array}{l}1.043^{*} \\
(0.161) \\
\end{array}$ & & & & & \\
\hline $\begin{array}{l}\ln \mathrm{COACH} \\
\text { F1 }\end{array}$ & & & & & $\begin{array}{l}0.393^{*} \\
(0.067)\end{array}$ & & & & \\
\hline $\begin{array}{l}\text { lnGOODS } \\
\text { F1 }\end{array}$ & & & & & & $\begin{array}{l}1.026^{*} \\
(0.159)\end{array}$ & & & \\
\hline lnCCAP F1 & & & & & & & $\begin{array}{l}0.676^{*} \\
(0.107)\end{array}$ & & \\
\hline InRPASS F1 & & & & & & & & $\begin{array}{l}0.432 * \\
(0.072)\end{array}$ & \\
\hline lnRFRT F1 & & & & & & & & & $\begin{array}{l}0.322^{*} \\
(0.057)\end{array}$ \\
\hline ECM & $\begin{array}{l}-0.36^{*} \\
(0.07)\end{array}$ & $\begin{array}{l}-0.39 * \\
(0.07)\end{array}$ & $\begin{array}{l}-0.39 * \\
(0.07)\end{array}$ & $\begin{array}{l}-0.33^{*} \\
(0.08)\end{array}$ & $\begin{array}{l}-0.33^{*} \\
(0.08)\end{array}$ & $\begin{array}{l}-0.33^{*} \\
(0.08)\end{array}$ & $\begin{array}{l}-0.33^{*} \\
(0.08)\end{array}$ & $\begin{array}{c}-0.33^{*} \\
(0.08)\end{array}$ & $\begin{array}{l}-0.34^{*} \\
(0.08)\end{array}$ \\
\hline h-test & $\begin{array}{c}3.69 \\
{[0.45]}\end{array}$ & $\begin{array}{c}3.46 \\
{[0.48]}\end{array}$ & $\begin{array}{c}3.42 \\
{[0.49]}\end{array}$ & $\begin{array}{c}5.29 \\
{[0.26]}\end{array}$ & $\begin{array}{c}5.62 \\
{[0.23]}\end{array}$ & $\begin{array}{c}5.29 \\
{[0.26]}\end{array}$ & $\begin{array}{c}5.31 \\
{[0.26]}\end{array}$ & $\begin{array}{c}5.54 \\
{[0.24]}\end{array}$ & $\begin{array}{c}5.78 \\
{[0.22]}\end{array}$ \\
\hline RLL & 636.84 & $\begin{array}{l}697.24 \\
\end{array}$ & 696.95 & 736.53 & 735.33 & 736.52 & 736.11 & 735.49 & 734.97 \\
\hline ULL & 753.02 & 848.90 & 825.86 & 914.37 & 917.86 & 914.40 & 915.52 & 917.37 & 919.00 \\
\hline LR: $\chi^{2}$ & $232.37^{*}$ & 303.33* & $257.82^{*}$ & $355.67^{*}$ & 365.05 & 355.77 & 358.83 & 363.77 & 368.05 \\
\hline
\end{tabular}




\begin{tabular}{|c|c|c|c|c|c|c|c|c|c|c|}
\hline \multicolumn{11}{|c|}{ TABLE 6B: Estimation Under Instrumented Infrastructure Measure } \\
\hline \multicolumn{11}{|c|}{ Dependent Variable: $\ln (\mathrm{Y} / \mathrm{L})$} \\
\hline & 13 & 14 & 15 & 16 & 17 & 18 & 19 & 20 & 21 & 22 \\
\hline ARDL: & $2,2,1,1$ & $3,2,2,0$ & $\mathbf{3 , 3 , 2 , 3}$ & $3,3,2,3$ & $3,3,2,1$ & $3,3,2,3$ & $3,3,2,1$ & $2,3,3,2$ & $2,3,3,1$ & $3,3,2,3$ \\
\hline $\ln (\mathrm{K} / \mathrm{L})$ & $\begin{array}{l}0.280^{*} \\
(0.088)\end{array}$ & $\begin{array}{l}0.519^{*} \\
(0.085)\end{array}$ & $\begin{array}{l}0.927^{*} \\
(0.085)\end{array}$ & $\begin{array}{l}0.908^{*} \\
(0.086) \\
\end{array}$ & $\begin{array}{l}0.485^{*} \\
(0.118)\end{array}$ & $\begin{array}{c}0.277^{*} \\
(0.085)\end{array}$ & $\begin{array}{l}0.507^{*} \\
(0.076)\end{array}$ & $\begin{array}{l}0.324^{*} \\
(0.099) \\
\end{array}$ & $\begin{array}{c}0.298^{*} \\
(0.121)\end{array}$ & $\begin{array}{l}0.922^{*} \\
(0.085)\end{array}$ \\
\hline SKRAT & $\begin{array}{c}- \\
0.086^{* *} \\
(0.047) \\
\end{array}$ & $\begin{array}{l}-0.121^{*} \\
(0.041)\end{array}$ & $\begin{array}{l}-0.189^{*} \\
(0.033)\end{array}$ & $\begin{array}{l}-0.188^{*} \\
(0.034)\end{array}$ & $\begin{array}{l}-0.129^{*} \\
(0.041)\end{array}$ & $\begin{array}{l}-0.163^{*} \\
(0.040)\end{array}$ & $\begin{array}{l}-0.144^{*} \\
(0.046)\end{array}$ & $\begin{array}{l}-0.166^{*} \\
(0.038)\end{array}$ & $\begin{array}{l}-0.143^{*} \\
(0.039)\end{array}$ & $\begin{array}{c}-0.189^{*} \\
(0.034)\end{array}$ \\
\hline NX & $\begin{array}{l}0.381^{*} \\
(0.026)\end{array}$ & $\begin{array}{l}0.172^{*} \\
(0.030)\end{array}$ & $\begin{array}{l}0.167^{*} \\
(0.034)\end{array}$ & $\begin{array}{l}0.169^{*} \\
(0.035)\end{array}$ & $\begin{array}{l}0.173^{*} \\
(0.026)\end{array}$ & $\begin{array}{l}0.188^{*} \\
(0.034)\end{array}$ & $\begin{array}{l}0.183^{*} \\
(0.026)\end{array}$ & $\begin{array}{l}0.194^{*} \\
(0.027)\end{array}$ & $\begin{array}{l}0.175^{*} \\
(0.023)\end{array}$ & $\begin{array}{c}0.167^{*} \\
(0.035)\end{array}$ \\
\hline GINI & - & - & - & - & - & - & - & - & - & - \\
\hline $\begin{array}{l}\text { lnTRDS } \\
\text { F2 }\end{array}$ & $\begin{array}{l}2.951^{*} \\
(1.293)\end{array}$ & & & & & & & & & \\
\hline $\begin{array}{l}\ln P R D S \\
\text { F1 }\end{array}$ & & $\begin{array}{l}1.075^{*} \\
(0.373)\end{array}$ & & & & & & & & \\
\hline $\begin{array}{l}\text { lnVEHP } \\
\text { F1 }\end{array}$ & & & $\begin{array}{l}0.432^{*} \\
(0.072)\end{array}$ & & & & & & & \\
\hline $\begin{array}{l}\ln V E H G \\
\text { F1 }\end{array}$ & & & & $\begin{array}{l}0.349^{*} \\
(0.060)\end{array}$ & & & & & & \\
\hline $\begin{array}{l}\text { lnPORTS } \\
\text { F2 }\end{array}$ & & & & & $\begin{array}{c}-0.025 \\
(0.027)\end{array}$ & & & & & \\
\hline $\begin{array}{l}\operatorname{lnSAA} \\
\text { F2 }\end{array}$ & & & & & & $\begin{array}{l}0.244^{*} \\
(0.061)\end{array}$ & & & & \\
\hline $\begin{array}{l}\text { lnAPASS } \\
\text { F2 }\end{array}$ & & & & & & & $\begin{array}{l}0.046^{*} \\
(0.017)\end{array}$ & & & \\
\hline $\begin{array}{l}\text { lnELEC } \\
\text { F2 }\end{array}$ & & & & & & & & $\begin{array}{l}0.059 * \\
(0.027)\end{array}$ & & \\
\hline $\begin{array}{l}\operatorname{lnFTEL} \\
\text { F2 }\end{array}$ & & & & & & & & & $\begin{array}{l}0.053^{* *} \\
(0.032) \\
\end{array}$ & \\
\hline $\begin{array}{l}\text { lnTEL } \\
\text { F1 }\end{array}$ & & & & & & & & & & $\begin{array}{l}0.406^{*} \\
(0.068)\end{array}$ \\
\hline & & & & & & & & & & \\
\hline ECM & $\begin{array}{l}-0.29 * \\
(0.05)\end{array}$ & $\begin{array}{c}-0.39 * \\
(0.07)\end{array}$ & $\begin{array}{l}-0.33^{*} \\
(0.08)\end{array}$ & $\begin{array}{l}-0.34^{*} \\
(0.08)\end{array}$ & $\begin{array}{l}-0.39 * \\
(0.07)\end{array}$ & $\begin{array}{l}-0.38^{*} \\
(0.07)\end{array}$ & $\begin{array}{l}-0.40^{*} \\
(0.06)\end{array}$ & $\begin{array}{l}-0.35^{*} \\
(0.06)\end{array}$ & $\begin{array}{l}-0.36^{*} \\
(0.06)\end{array}$ & $\begin{array}{c}-0.33^{*} \\
(0.08)\end{array}$ \\
\hline h-test & $\begin{array}{c}1.97 \\
{[0.74]}\end{array}$ & $\begin{array}{c}3.50 \\
{[0.48]}\end{array}$ & $\begin{array}{l}5.54^{*} \\
{[0.24]}\end{array}$ & $\begin{array}{c}5.72 \\
{[0.22]}\end{array}$ & $\begin{array}{c}6.54 \\
{[0.16]}\end{array}$ & $\begin{array}{c}3.99 \\
{[0.41]}\end{array}$ & $\begin{array}{c}7.31 \\
{[0.12]}\end{array}$ & $\begin{array}{c}3.32 \\
{[0.51]}\end{array}$ & $\begin{array}{c}4.22 \\
{[0.38]}\end{array}$ & $\begin{array}{c}5.59 \\
{[0.23]}\end{array}$ \\
\hline RLL & 655.48 & 669.70 & 735.49 & 735.12 & 696.71 & 735.35 & 698.95 & 714.27 & 698.42 & 735.39 \\
\hline ULL & 746.84 & 788.74 & 917.37 & 918.52 & 815.21 & 934.50 & 803.49 & 852.25 & 816.46 & 917.69 \\
\hline LR: $\chi^{2}$ & $182.73^{*}$ & $238.08^{*}$ & $363.75^{*}$ & $366.81^{*}$ & $237.01^{*}$ & 398.30* & $209.08^{*}$ & $275.97^{*}$ & 236.07* & 364.61* \\
\hline
\end{tabular}




\begin{tabular}{|c|c|c|c|c|c|c|c|}
\hline \multicolumn{8}{|c|}{ TABLE 7: Results of SURE Instrumenting Estimation } \\
\hline \multicolumn{8}{|c|}{ Dependent Variable: Private Sector R\&D } \\
\hline Sector & $\begin{array}{l}\text { Public } \\
\text { R\&D }\end{array}$ & $\begin{array}{l}\text { Tertiary } \\
\text { R\&D }\end{array}$ & $\begin{array}{l}\chi^{2} \\
\{\text { d.f. }\}\end{array}$ & Sector & $\begin{array}{l}\text { Public } \\
\text { R\&D }\end{array}$ & $\begin{array}{l}\text { Tertiary } \\
\text { R\&D }\end{array}$ & $\begin{array}{l}\chi^{2} \\
\{\text { d.f. }\}\end{array}$ \\
\hline Food & $\begin{array}{l}1.68 \\
(0.12) \\
\end{array}$ & $\begin{array}{l}1.26 \\
(0.50) \\
\end{array}$ & $\begin{array}{l}260.71^{*} \\
\{15\}\end{array}$ & Plastics & $\begin{array}{l}-0.02 \\
(0.06) \\
\end{array}$ & $\begin{array}{l}10.95 \\
(1.08) \\
\end{array}$ & $\begin{array}{l}279.81 * \\
\{15\}\end{array}$ \\
\hline Beverages & $\begin{array}{l}1.20 \\
(0.55)\end{array}$ & $\begin{array}{l}0.38 \\
(0.50)\end{array}$ & $\begin{array}{l}260.71^{*} \\
\{15\}\end{array}$ & Glass & $\begin{array}{l}5.58 \\
(0.58)\end{array}$ & $\begin{array}{l}1.41 \\
(0.20)\end{array}$ & $\begin{array}{l}279.81 * \\
\{15\}\end{array}$ \\
\hline Textiles & $\begin{array}{l}0.25 \\
(0.03)\end{array}$ & $\begin{array}{l}-12.02 \\
(2.74)\end{array}$ & $\begin{array}{l}260.71^{*} \\
\{15\}\end{array}$ & $\begin{array}{l}\text { Non- } \\
\text { Metallic }\end{array}$ & $\begin{array}{l}0.43 \\
(0.20)\end{array}$ & $\begin{array}{l}1.94 \\
(0.59)\end{array}$ & $\begin{array}{l}\text { 131.40* } \\
\{6\}\end{array}$ \\
\hline $\begin{array}{l}\text { Wearing } \\
\text { Apparel }\end{array}$ & - & $\begin{array}{l}-0.11 \\
(0.06) \\
\end{array}$ & $\begin{array}{l}\text { 260.71* } \\
\{15\} \\
\end{array}$ & $\begin{array}{l}\text { Basic Iron } \\
\text { \& Steel }\end{array}$ & $\begin{array}{l}5.36 \\
(0.90) \\
\end{array}$ & $\begin{array}{l}17.81 \\
(3.49) \\
\end{array}$ & $\begin{array}{l}\text { 131.40* } \\
\{6\}\end{array}$ \\
\hline Leather & - & $\begin{array}{l}-0.19 \\
(0.05)\end{array}$ & $\begin{array}{l}260.71 * \\
\{15\}\end{array}$ & $\begin{array}{l}\text { Basic Non- } \\
\text { Ferrous }\end{array}$ & $\begin{array}{l}0.10 \\
(0.03)\end{array}$ & $\begin{array}{l}0.60 \\
(0.40)\end{array}$ & $\begin{array}{l}131.40 * \\
\{6\}\end{array}$ \\
\hline Footwear & $\begin{array}{l}3917 \\
(1354.2)\end{array}$ & & $\begin{array}{l}1837.60^{*} \\
\{20\}\end{array}$ & $\begin{array}{l}\text { Metal } \\
\text { Products }\end{array}$ & $\begin{array}{l}10.26 \\
(1.49)\end{array}$ & $\begin{array}{l}-7.89 \\
(5.08)\end{array}$ & $\begin{array}{l}131.40 * \\
\{6\}\end{array}$ \\
\hline Wood & $\begin{array}{l}0.14 \\
(0.13)\end{array}$ & $\begin{array}{l}0.76 \\
(0.57)\end{array}$ & $\begin{array}{l}260.71^{*} \\
\{15\}\end{array}$ & Machinery & $\begin{array}{l}0.61 \times 10^{-7} \\
\left(0.86 \times 10^{-7}\right)\end{array}$ & $\begin{array}{l}0.38 \times 10^{-5} \\
\left(0.49 \times 10^{-5}\right)\end{array}$ & $\begin{array}{l}188.50 * \\
\{20\}\end{array}$ \\
\hline Paper $\neq$ & $\begin{array}{l}2658.1 \\
(1156) \\
\end{array}$ & & $\begin{array}{l}1837.60^{*} \\
\{20\}\end{array}$ & $\begin{array}{l}\text { Eletr. } \\
\text { Machinery }\end{array}$ & $\begin{array}{l}-0.55 \times 10^{-8} \\
\left(0.26 \times 10^{-7}\right)\end{array}$ & $\begin{array}{l}0.41 \times 10^{-6} \\
\left(0.38 \times 10^{-7}\right)\end{array}$ & $\begin{array}{l}188.50 * \\
\{20\}\end{array}$ \\
\hline $\begin{array}{l}\text { Print \& } \\
\text { Publish } \dagger\end{array}$ & & $\begin{array}{l}6.96 \\
(2.28) \\
\end{array}$ & $\begin{array}{l}1837.60^{*} \\
\{20\}\end{array}$ & $\begin{array}{l}\text { Motor } \\
\text { Vehicles }\end{array}$ & $\begin{array}{l}-0.16 \\
(0.38) \\
\end{array}$ & $\begin{array}{l}14.74 \\
(1.94)\end{array}$ & $\begin{array}{l}188.50 * \\
\{20\}\end{array}$ \\
\hline $\begin{array}{l}\text { Basic } \\
\text { Chemicals }\end{array}$ & $\begin{array}{l}1.92 \\
(0.21)\end{array}$ & $\begin{array}{l}11.26 \\
(0.31)\end{array}$ & $\begin{array}{l}279.81^{*} \\
\{15\}\end{array}$ & Furniture & $\begin{array}{l}-0.14 \times 10^{-4} \\
\left(0.38 \times 10^{-5}\right)\end{array}$ & $\begin{array}{l}-0.14 \times 10^{-4} \\
\left(0.38 \times 10^{-5}\right)\end{array}$ & $\begin{array}{l}1837.60 * \\
\{20\}\end{array}$ \\
\hline $\begin{array}{l}\text { Other } \\
\text { Chemicals }\end{array}$ & $\begin{array}{l}0.36 \\
(0.02)\end{array}$ & $\begin{array}{l}4.93 \\
(0.17)\end{array}$ & $\begin{array}{l}279.81^{*} \\
\{15\}\end{array}$ & $\begin{array}{l}\text { Other } \\
\text { Industry }\end{array}$ & $\begin{array}{l}0.86 \times 10^{-6} \\
\left(0.15 \times 10^{-6}\right)\end{array}$ & $\begin{array}{l}0.27 \times 10^{-5} \\
\left(0.43 \times 10^{-6}\right)\end{array}$ & $\begin{array}{l}188.50^{*} \\
\{20\}\end{array}$ \\
\hline Rubber & $\begin{array}{l}-1.43 \\
(0.52)\end{array}$ & - & $\begin{array}{l}\text { 279.81* } \\
\{15\}\end{array}$ & & & & \\
\hline
\end{tabular}




\begin{tabular}{|c|c|c|c|c|c|c|c|c|c|}
\hline \multicolumn{10}{|c|}{ TABLE 8A: Estimation Under Non-Instrumented Infrastructure Measure } \\
\hline \multicolumn{10}{|c|}{ Dependent Variable: Growth in Total Factor Productivity } \\
\hline & 1 & 2 & 3 & 4 & 5 & 6 & 7 & 8 & 9 \\
\hline ARDL: & $3,3,2,1,3$ & $3,3,2,1,3$ & $3,3,2,1,3$ & $3,3,2,1,3$ & \begin{tabular}{|l|}
$3,3,2,1,3$ \\
\end{tabular} & $3,3,2,1,3$ & \begin{tabular}{|l|l|}
$3,3,2,1,3$ \\
\end{tabular} & $3,3,2,1,3$ & $3,3,2,1,3$ \\
\hline $\ln (\mathrm{R} \& \mathrm{D} / \mathrm{Y} / \mathrm{L})$ & $\begin{array}{l}0.042 * \\
(0.011)\end{array}$ & $\begin{array}{l}0.040^{*} \\
(0.011)\end{array}$ & $\begin{array}{l}0.036^{*} \\
(0.011)\end{array}$ & $\begin{array}{c}0.001 \\
(0.008)\end{array}$ & $\begin{array}{l}0.058^{*} \\
(0.013)\end{array}$ & $\begin{array}{l}0.118^{*} \\
(0.016)\end{array}$ & $\begin{array}{l}0.031^{*} \\
(0.010)\end{array}$ & $\begin{array}{l}0.034^{*} \\
(0.011)\end{array}$ & $\begin{array}{l}0.033^{*} \\
(0.011)\end{array}$ \\
\hline SKRAT & $\begin{array}{c}-0.054^{*} \\
(0.019)\end{array}$ & $\begin{array}{l}-0.032^{*} \\
(0.017)\end{array}$ & $\begin{array}{c}-0.032^{*} \\
(0.016)\end{array}$ & $\begin{array}{c}-0.092^{*} \\
(0.022)\end{array}$ & $\begin{array}{c}-0.044^{*} \\
(0.016)\end{array}$ & $\begin{array}{c}-0.037^{*} \\
(0.014)\end{array}$ & $\begin{array}{l}-0.041^{*} \\
(0.017)\end{array}$ & $\begin{array}{c}-0.049^{*} \\
(0.018)\end{array}$ & $\begin{array}{l}-0.045^{*} \\
(0.019)\end{array}$ \\
\hline NX & $\begin{array}{c}-0.023 \\
(0.024)\end{array}$ & $\begin{array}{l}0.098^{*} \\
(0.016)\end{array}$ & $\begin{array}{l}0.109^{*} \\
(0.015)\end{array}$ & $\begin{array}{l}0.123 * \\
(0.021)\end{array}$ & $\begin{array}{l}0.042^{*} \\
(0.019)\end{array}$ & $\begin{array}{l}0.065^{*} \\
(0.019)\end{array}$ & $\begin{array}{l}0.096^{*} \\
(0.018)\end{array}$ & $\begin{array}{c}0.027 \\
(0.022)\end{array}$ & $\begin{array}{l}0.092^{*} \\
(0.019)\end{array}$ \\
\hline GINI & $\begin{array}{c}-0.513^{*} \\
(0.130)\end{array}$ & $\begin{array}{c}-0.149 \\
(0.162)\end{array}$ & $\begin{array}{c}-0.140 \\
(0.171)\end{array}$ & $\begin{array}{c}-0.332^{*} \\
(0.103)\end{array}$ & $\begin{array}{c}-0.332^{*} \\
(0.127)\end{array}$ & $\begin{array}{c}-0.372^{*} \\
(0.108)\end{array}$ & $\begin{array}{c}-0.234 \\
(0.162)\end{array}$ & $\begin{array}{c}-0.354^{*} \\
(0.128)\end{array}$ & $\begin{array}{c}-0.186 \\
(0.164)\end{array}$ \\
\hline lnGFCF & $\begin{array}{c}-0.076^{*} \\
(0.017)\end{array}$ & & & & & & & & \\
\hline $\operatorname{lnFCS}$ & & $\begin{array}{c}-0.117^{*} \\
(0.033)\end{array}$ & & & & & & & \\
\hline lnRAIL & & & $\begin{array}{c}-0.605^{*} \\
(0.164)\end{array}$ & & & & & & \\
\hline $\operatorname{lnLOCO}$ & & & & $\begin{array}{c}-0.125^{*} \\
(0.026)\end{array}$ & & & & & \\
\hline $\operatorname{lnCOACH}$ & & & & & $\begin{array}{c}0.016 \\
(0.025)\end{array}$ & & & & \\
\hline $\operatorname{lnGOODS}$ & & & & & & $\begin{array}{l}0.145^{*} \\
(0.045)\end{array}$ & & & \\
\hline $\operatorname{lnCCAP}$ & & & & & & & $\begin{array}{c}-0.157^{*} \\
(0.056)\end{array}$ & & \\
\hline lnRPASS & & & & & & & & $\begin{array}{l}-0.050^{*} \\
(0.021)\end{array}$ & \\
\hline $\operatorname{lnRFRT}$ & & & & & & & & & $\begin{array}{c}-0.084^{*} \\
(0.039)\end{array}$ \\
\hline ECM & $\begin{array}{l}-1.12^{*} \\
(0.13) \\
\end{array}$ & $\begin{array}{l}-1.16^{*} \\
(0.12) \\
\end{array}$ & $\begin{array}{l}-1.15^{*} \\
(0.11)\end{array}$ & $\begin{array}{c}-1.23^{*} \\
(0.15)\end{array}$ & $\begin{array}{l}-1.11^{*} \\
(0.15)\end{array}$ & $\begin{array}{c}-1.03^{*} \\
(0.16)\end{array}$ & $\begin{array}{c}-1.17^{*} \\
(0.13)\end{array}$ & $\begin{array}{l}-1.14^{*} \\
(0.12)\end{array}$ & $\begin{array}{c}-1.12^{*} \\
(0.11)\end{array}$ \\
\hline h-test & $\begin{array}{c}7.49 \\
{[0.19]}\end{array}$ & $\begin{array}{c}9.58 \\
{[0.09]}\end{array}$ & $\begin{array}{c}7.02 \\
{[0.22]}\end{array}$ & $\begin{array}{c}4.62 \\
{[0.46]}\end{array}$ & $\begin{array}{c}7.12 \\
{[0.21]}\end{array}$ & $\begin{array}{c}9.57 \\
{[0.09]}\end{array}$ & $\begin{array}{c}8.39 \\
{[0.14]}\end{array}$ & $\begin{array}{c}8.44 \\
{[0.13]}\end{array}$ & $\begin{array}{c}6.82 \\
{[0.23]}\end{array}$ \\
\hline RLL & 593.68 & 591.10 & 591.11 & 590.24 & 588.81 & 590.83 & 588.67 & 589.21 & 588.74 \\
\hline ULL & 853.43 & 884.01 & 840.75 & 879.09 & 868.86 & 849.45 & 872.98 & 879.48 & 831.12 \\
\hline LR: $\chi^{2}$ & 519.49* & $585.81^{*}$ & 499.29* & $577.70^{*}$ & $560.10^{*}$ & 517.25* & $568.61^{*}$ & $580.54 *$ & $484.75^{*}$ \\
\hline
\end{tabular}




\begin{tabular}{|c|c|c|c|c|c|c|c|c|c|c|}
\hline \multicolumn{11}{|c|}{ TABLE 8B: Estimation Under Non-Instrumented Infrastructure Measure } \\
\hline \multicolumn{11}{|c|}{ Dependent Variable: Growth in Total Factor Productivity } \\
\hline & 10 & 11 & 12 & 13 & 14 & 15 & 16 & 17 & 18 & 19 \\
\hline ARDL: & $3,3,2,1,3$ & $3,3,2,1,3$ & $3,3,2,1,3$ & $3,3,2,1,3$ & $3,3,2,1,3$ & $3,3,2,1,3$ & $3,3,2,1,3$ & $3,3,2,1,3$ & $3,3,2,1,3$ & $3,3,2,1,3$ \\
\hline $\ln (\mathrm{R} \& \mathrm{D} / \mathrm{Y} / \mathrm{L})$ & $\begin{array}{l}0.013^{*} \\
(0.006)\end{array}$ & $\begin{array}{l}0.057^{*} \\
(0.012)\end{array}$ & $\begin{array}{l}0.054^{*} \\
(0.012)\end{array}$ & $\begin{array}{l}0.053^{*} \\
(0.012)\end{array}$ & $\begin{array}{l}0.058^{*} \\
(0.013)\end{array}$ & $\begin{array}{l}0.048^{*} \\
(0.012)\end{array}$ & $\begin{array}{l}0.082^{*} \\
(0.015)\end{array}$ & $\begin{array}{l}0.061^{*} \\
(0.013)\end{array}$ & $\begin{array}{l}0.064^{*} \\
(0.013)\end{array}$ & $\begin{array}{l}0.056^{*} \\
(0.012)\end{array}$ \\
\hline SKRAT & $\begin{array}{c}-0.078^{*} \\
(0.015)\end{array}$ & $\begin{array}{c}-0.021 \\
(0.015)\end{array}$ & $\begin{array}{c}-0.025^{*} \\
(0.015)\end{array}$ & $\begin{array}{c}-0.025^{* *} \\
(0.015)\end{array}$ & $\begin{array}{c}-0.053^{*} \\
(0.017)\end{array}$ & $\begin{array}{c}-0.047^{*} \\
(0.018)\end{array}$ & $\begin{array}{c}-0.046^{*} \\
(0.014)\end{array}$ & $\begin{array}{c}-0.027^{* *} \\
(0.016)\end{array}$ & $\begin{array}{c}-0.026^{* * *} \\
(0.016)\end{array}$ & $\begin{array}{l}-0.023 \\
(0.016)\end{array}$ \\
\hline $\mathrm{NX}$ & $\begin{array}{l}0.040^{*} \\
(0.017)\end{array}$ & $\begin{array}{l}0.104^{*} \\
(0.014)\end{array}$ & $\begin{array}{c}0.098 \\
(0.015)\end{array}$ & $\begin{array}{l}0.098^{*} \\
(0.015)\end{array}$ & $\begin{array}{c}0.015 \\
(0.021)\end{array}$ & $\begin{array}{l}0.038^{*} \\
(0.019)\end{array}$ & $\begin{array}{l}0.050^{*} \\
(0.017)\end{array}$ & $\begin{array}{l}0.102^{*} \\
(0.016)\end{array}$ & $\begin{array}{l}0.102^{*} \\
(0.016)\end{array}$ & $\begin{array}{l}0.098^{*} \\
(0.015)\end{array}$ \\
\hline GINI & $\begin{array}{c}-0.649^{*} \\
(0.116)\end{array}$ & $\begin{array}{c}0.002 \\
(0.146)\end{array}$ & $\begin{array}{c}-0.129 \\
(0.147)\end{array}$ & $\begin{array}{l}-0.111 \\
(0.152)\end{array}$ & $\begin{array}{c}-0.532^{*} \\
(0.161)\end{array}$ & $\begin{array}{c}-0.365^{*} \\
(0.158)\end{array}$ & $\begin{array}{c}-0.243^{*} \\
(0.123)\end{array}$ & $\begin{array}{c}-0.143 \\
(0.146)\end{array}$ & $\begin{array}{c}-0.137 \\
(0.145)\end{array}$ & $\begin{array}{l}-0.078 \\
(0.152)\end{array}$ \\
\hline $\operatorname{lnTRDS}$ & $\begin{array}{l}0.017^{*} \\
(0.002)\end{array}$ & & & & & & & & & \\
\hline $\operatorname{lnPRDS}$ & & $\begin{array}{c}-0.252^{*} \\
(0.047)\end{array}$ & & & & & & & & \\
\hline $\operatorname{lnVEHP}$ & & & $\begin{array}{c}-0.098^{*} \\
(0.022)\end{array}$ & & & & & & & \\
\hline $\operatorname{lnVEHG}$ & & & & $\begin{array}{c}-0.099 * \\
(0.022)\end{array}$ & & & & & & \\
\hline $\operatorname{lnPORTS}$ & & & & & $\begin{array}{l}0.032^{*} \\
(0.017)\end{array}$ & & & & & \\
\hline $\operatorname{lnSAA}$ & & & & & & $\begin{array}{c}0.012 \\
(0.029)\end{array}$ & & & & \\
\hline $\ln$ APASS & & & & & & & $\begin{array}{l}-0.065^{*} \\
(0.019)\end{array}$ & & & \\
\hline InELEC & & & & & & & & $\begin{array}{c}-0.051^{*} \\
(0.012)\end{array}$ & & \\
\hline InFTEL & & & & & & & & & $\begin{array}{c}-0.050^{*} \\
(0.012)\end{array}$ & \\
\hline InTEL & & & & & & & & & & $\begin{array}{c}-0.071^{*} \\
(0.016)\end{array}$ \\
\hline & & & & & & & & & & \\
\hline ECM & $\begin{array}{l}-1.27^{*} \\
(0.21)\end{array}$ & $\begin{array}{c}-1.16^{*} \\
(0.12)\end{array}$ & $\begin{array}{l}-1.16^{*} \\
(0.12)\end{array}$ & $\begin{array}{l}-1.16^{*} \\
(0.12)\end{array}$ & $\begin{array}{l}-1.11^{*} \\
(0.14)\end{array}$ & $\begin{array}{l}-1.13^{*} \\
(0.13)\end{array}$ & $\begin{array}{c}-1.06^{*} \\
(0.14)\end{array}$ & $\begin{array}{l}-1.13^{*} \\
(0.12)\end{array}$ & $\begin{array}{l}-1.13^{*} \\
(0.12)\end{array}$ & $\begin{array}{l}-1.15^{*} \\
(0.12)\end{array}$ \\
\hline h-test & $\begin{array}{c}5.03 \\
{[0.41]}\end{array}$ & $\begin{array}{l}11.07^{*} \\
{[0.05]}\end{array}$ & $\begin{array}{c}11.37^{*} \\
{[0.04]}\end{array}$ & $\begin{array}{c}14.47^{*} \\
{[0.01]}\end{array}$ & $\begin{array}{c}5.18 \\
{[0.39]}\end{array}$ & $\begin{array}{c}3.77 \\
{[0.58]}\end{array}$ & $\begin{array}{c}5.85 \\
{[0.32]}\end{array}$ & $\begin{array}{l}11.52^{*} \\
{[0.04]}\end{array}$ & $\begin{array}{l}12.32^{*} \\
{[0.03]}\end{array}$ & $\begin{array}{c}7.02 \\
{[0.22]}\end{array}$ \\
\hline RLL & 599.25 & 595.95 & 593.53 & 593.05 & 589.61 & 588.67 & 591.60 & 592.04 & 592.04 & 592.94 \\
\hline ULL & 947.02 & 845.97 & 860.18 & 842.65 & 852.14 & 869.65 & 863.63 & 862.40 & 868.49 & 850.72 \\
\hline LR: $\chi^{2}$ & 695.55* & $500.04^{*}$ & $533.28^{*}$ & $499.21^{*}$ & $525.05^{*}$ & $561.95^{*}$ & $544.05^{*}$ & $540.71^{*}$ & $552.90^{*}$ & $515.56 *$ \\
\hline
\end{tabular}




\begin{tabular}{|c|c|c|c|c|c|c|c|c|c|}
\hline \multicolumn{10}{|c|}{ TABLE 9A: Estimation Under Instrumented Infrastructure Measure } \\
\hline \multicolumn{10}{|c|}{ Dependent Variable: Growth in Total Factor Productivity } \\
\hline & 1 & 2 & 3 & 4 & 5 & 6 & 7 & 8 & 9 \\
\hline ARDL: & $3,3,2,1,2$ & $3,3,2,1,3$ & $3,3,2,1,2$ & $3,3,2,2,3$ & $3,3,2,2,3$ & $3,3,3,1,3$ & $\mathbf{3 , 3}, \mathbf{3}, \mathbf{1}, \mathbf{3}$ & $3,3,2,2,3$ & $3,3,2,1,3$ \\
\hline $\ln (\mathrm{R} \& \mathrm{D} / \mathrm{Y} / \mathrm{L})$ & $\begin{array}{l}0.067^{*} \\
(0.014)\end{array}$ & $\begin{array}{l}0.042^{*} \\
(0.012)\end{array}$ & $\begin{array}{l}0.058^{*} \\
(0.013) \\
\end{array}$ & $\begin{array}{l}0.066^{*} \\
(0.014) \\
\end{array}$ & $\begin{array}{l}0.076^{*} \\
(0.015)\end{array}$ & $\begin{array}{l}0.020^{*} \\
(0.010) \\
\end{array}$ & $\begin{array}{l}0.018^{*} \\
(0.010)\end{array}$ & $\begin{array}{l}0.087^{*} \\
(0.016)\end{array}$ & $\begin{array}{l}0.133^{*} \\
(0.015)\end{array}$ \\
\hline SKRAT & $\begin{array}{l}-0.076^{*} \\
(0.018)\end{array}$ & $\begin{array}{l}-0.044^{*} \\
(0.017)\end{array}$ & $\begin{array}{l}-0.077^{*} \\
(0.019)\end{array}$ & $\begin{array}{l}-0.051^{*} \\
(0.014)\end{array}$ & $\begin{array}{l}-0.050^{*} \\
(0.014)\end{array}$ & $\begin{array}{c}-0.031^{* *} \\
(0.017)\end{array}$ & $\begin{array}{c}-0.032^{*} \\
(0.018)\end{array}$ & $\begin{array}{l}-0.049^{*} \\
(0.014)\end{array}$ & $\begin{array}{l}-0.047^{*} \\
(0.014)\end{array}$ \\
\hline NX & $\begin{array}{l}0.074^{*} \\
(0.021)\end{array}$ & $\begin{array}{c}0.033 \\
(0.021)\end{array}$ & $\begin{array}{l}0.066^{*} \\
(0.022)\end{array}$ & $\begin{array}{c}0.006 \\
(0.024)\end{array}$ & $\begin{array}{c}0.012 \\
(0.023)\end{array}$ & $\begin{array}{l}0.142^{*} \\
(0.017)\end{array}$ & $\begin{array}{l}0.144^{*} \\
(0.017)\end{array}$ & $\begin{array}{c}0.014 \\
(0.024)\end{array}$ & $\begin{array}{l}0.049^{*} \\
(0.020)\end{array}$ \\
\hline GINI & $\begin{array}{l}-0.358^{*} \\
(0.106)\end{array}$ & $\begin{array}{l}-0.304^{*} \\
(0.131)\end{array}$ & $\begin{array}{l}-0.366^{*} \\
(0.106)\end{array}$ & $\begin{array}{l}-0.135 \\
(0.130)\end{array}$ & $\begin{array}{l}-0.156 \\
(0.122)\end{array}$ & $\begin{array}{l}-0.962^{*} \\
(0.168)\end{array}$ & $\begin{array}{l}-1.024^{*} \\
(0.169)\end{array}$ & $\begin{array}{l}-0.229^{*} \\
(0.112)\end{array}$ & $\begin{array}{l}-0.343^{*} \\
(0.127)\end{array}$ \\
\hline lnGFCF F2 & $\begin{array}{l}0.038^{*} \\
(0.019)\end{array}$ & & & & & & & & \\
\hline $\operatorname{lnFCS~F2~}$ & & $\begin{array}{l}-0.047 \\
(0.046)\end{array}$ & & & & & & & \\
\hline lnRAIL F2 & & & $\begin{array}{c}0.072 \\
(0.124)\end{array}$ & & & & & & \\
\hline $\operatorname{lnLOCO~F2~}$ & & & & $\begin{array}{l}0.052^{*} \\
(0.025) \\
\end{array}$ & & & & & \\
\hline $\begin{array}{l}\ln \mathrm{ln} \mathrm{ACH} \\
\text { F2 }\end{array}$ & & & & & $\begin{array}{l}0.029^{*} \\
(0.012)\end{array}$ & & & & \\
\hline $\begin{array}{l}\text { lnGOODS } \\
\text { F2 }\end{array}$ & & & & & & $\begin{array}{l}0.049^{*} \\
(0.019)\end{array}$ & & & \\
\hline $\operatorname{lnCCAP~F2~}$ & & & & & & & $\begin{array}{l}0.051^{*} \\
(0.026)\end{array}$ & & \\
\hline lnRPASS F2 & & & & & & & & $\begin{array}{l}0.159^{*} \\
(0.071)\end{array}$ & \\
\hline lnRFRT F2 & & & & & & & & & $\begin{array}{l}0.184^{*} \\
(0.038)\end{array}$ \\
\hline ECM & $\begin{array}{l}-1.04^{*} \\
(0.15)\end{array}$ & $\begin{array}{l}-1.13^{*} \\
(0.12)\end{array}$ & $\begin{array}{l}-1.036^{*} \\
(0.141)\end{array}$ & $\begin{array}{l}-1.074^{*} \\
(0.124)\end{array}$ & $\begin{array}{l}-1.063^{*} \\
(0.129)\end{array}$ & $\begin{array}{l}-1.119^{*} \\
(0.123)\end{array}$ & $\begin{array}{l}-1.11^{*} \\
(0.12)\end{array}$ & $\begin{array}{l}-1.05^{*} \\
(0.13)\end{array}$ & $\begin{array}{l}-1.02^{*} \\
(0.18)\end{array}$ \\
\hline h-test & $\begin{array}{c}8.32 \\
{[0.14]}\end{array}$ & $\begin{array}{l}10.39 \\
{[0.06]}\end{array}$ & $\begin{array}{c}8.73 \\
{[0.12]}\end{array}$ & $\begin{array}{c}5.05 \\
{[0.41]}\end{array}$ & $\begin{array}{c}3.48 \\
{[0.63]}\end{array}$ & $\begin{array}{c}9.98 \\
{[0.08]}\end{array}$ & $\begin{array}{l}10.72 \\
{[0.06]}\end{array}$ & $\begin{array}{c}6.46 \\
{[0.26]}\end{array}$ & $\begin{array}{c}5.61 \\
{[0.35]}\end{array}$ \\
\hline RLL & 553.45 & 588.66 & 552.21 & 647.88 & 648.23 & 616.60 & 615.77 & 647.47 & 594.81 \\
\hline ULL & 788.47 & 860.21 & 773.25 & 960.59 & 973.35 & 971.90 & 960.32 & 977.23 & 859.27 \\
\hline LR: $\chi^{2}$ & 470.04* & $543.10^{*}$ & $442.08^{*}$ & $625.41^{*}$ & $650.25^{*}$ & $710.60^{*}$ & $689.12^{*}$ & $659.52^{*}$ & $528.92^{*}$ \\
\hline
\end{tabular}


TABLE 9B: Estimation Under Instrumented Infrastructure Measure

Dependent Variable: Growth in Total Factor Productivity

\begin{tabular}{|c|c|c|c|c|c|c|c|c|c|c|c|}
\hline & 10 & $11 \mathrm{a}$ & $11 b$ & $12 \mathrm{a}$ & $12 b$ & $13 a$ & $13 \mathrm{~b}$ & $13 c$ & 13d & $14 \mathrm{a}$ & $14 \mathrm{~b}$ \\
\hline ARDL: & $3,3,2,1,3$ & $3,3,3,1,3$ & $3,3,2,1,3$ & $3,3,2,1,3$ & $2,3,1,3,3,0$ & $3,3,2,1,3$ & $2,3,1,3,3,0$ & $3,3,2,2,2,0$ & $3,3,1,2,3,0,0$ & $3, \mathbf{3}, \mathbf{3}, \mathbf{3}, \mathbf{3}$ & $3,3,1,1,3,3$ \\
\hline $\ln (\mathrm{R} \& \mathrm{D} / \mathrm{Y} / \mathrm{L})$ & $\begin{array}{l}0.039^{*} \\
(0.010)\end{array}$ & $\begin{array}{l}0.025^{*} \\
(0.009)\end{array}$ & $\begin{array}{l}0.060^{*} \\
(0.013)\end{array}$ & $\begin{array}{l}0.039 * \\
(0.012)\end{array}$ & $\begin{array}{l}0.027^{*} \\
(0.004)\end{array}$ & $\begin{array}{l}0.031^{*} \\
(0.010)\end{array}$ & $\begin{array}{c}0.009^{* *} \\
(0.005)\end{array}$ & $\begin{array}{l}0.047^{*} \\
(0.010)\end{array}$ & $\begin{array}{l}0.044^{*} \\
(0.012)\end{array}$ & $\begin{array}{l}0.057^{*} \\
(0.010)\end{array}$ & $\begin{array}{l}0.051^{*} \\
(0.005)\end{array}$ \\
\hline SKRAT & $\begin{array}{l}-0.035^{*} \\
(0.017)\end{array}$ & $\begin{array}{l}-0.017 \\
(0.017)\end{array}$ & $\begin{array}{c}-0.028^{* *} \\
(0.016)\end{array}$ & $\begin{array}{l}-0.049 * \\
(0.018)\end{array}$ & $\begin{array}{l}-0.045^{*} \\
(0.018)\end{array}$ & $\begin{array}{l}-0.038^{*} \\
(0.017)\end{array}$ & $\begin{array}{l}-0.036 \\
(0.021)\end{array}$ & $\begin{array}{l}-0.063^{*} \\
(0.019)\end{array}$ & $\begin{array}{c}0.003 \\
(0.020)\end{array}$ & $\begin{array}{l}-0.023 \\
(0.018)\end{array}$ & $\begin{array}{l}0.002 \\
(0.02)\end{array}$ \\
\hline $\mathrm{NX}$ & $\begin{array}{l}0.053^{*} \\
(0.018)\end{array}$ & $\begin{array}{l}0.123^{*} \\
(0.017)\end{array}$ & $\begin{array}{l}0.102^{*} \\
(0.016)\end{array}$ & $\begin{array}{c}0.016 \\
(0.022)\end{array}$ & $\begin{array}{l}-3.282 * \\
(0.331)\end{array}$ & $\begin{array}{l}0.084^{*} \\
(0.017)\end{array}$ & $\begin{array}{c}4.23 * \\
(1.307)\end{array}$ & $\begin{array}{l}0.038^{*} \\
(0.020)\end{array}$ & $\begin{array}{l}-0.476 \\
(1.748)\end{array}$ & $\begin{array}{l}-0.088^{*} \\
(0.018)\end{array}$ & $\begin{array}{l}-1.704 * \\
(0.281)\end{array}$ \\
\hline GINI & $\begin{array}{c}-0.032 \\
(0.130) \\
\end{array}$ & $\begin{array}{l}-0.705^{*} \\
(0.192) \\
\end{array}$ & $\begin{array}{l}-0.167 \\
(0.149) \\
\end{array}$ & $\begin{array}{l}-0.293^{*} \\
(0.126) \\
\end{array}$ & $\begin{array}{c}-0.168 \\
(0.105) \\
\end{array}$ & $\begin{array}{c}-0.247 \\
(0.154) \\
\end{array}$ & $\begin{array}{c}-0.044 \\
(0.113) \\
\end{array}$ & $\begin{array}{l}59.692 * \\
(8.188) \\
\end{array}$ & $\begin{array}{l}48.583^{*} \\
(11.013) \\
\end{array}$ & $\begin{array}{l}-0.417^{*} \\
(0.066) \\
\end{array}$ & $\begin{array}{c}-0.130 \\
(0.144) \\
\end{array}$ \\
\hline lnTRDS F2 & $\begin{array}{l}2.802^{*} \\
(0.512)\end{array}$ & & & & & & & & & & \\
\hline lnPRDS F2 & & $\begin{array}{l}-0.445^{*} \\
(0.093)\end{array}$ & & & & & & & & & \\
\hline $\operatorname{lnRDSSHT}$ & & & $\begin{array}{l}4.940^{*} \\
(1.294) \\
\end{array}$ & & & & & & & & \\
\hline $\operatorname{lnVEHP}$ & & & & $\begin{array}{l}-0.034^{*} \\
(0.013)\end{array}$ & $\begin{array}{l}0.077^{*} \\
(0.011)\end{array}$ & & & & & & \\
\hline $\ln V E H G$ & & & & & & $\begin{array}{l}-0.170^{*} \\
(0.053) \\
\end{array}$ & $\begin{array}{l}-0.304^{*} \\
(0.078) \\
\end{array}$ & $\begin{array}{l}3.056^{*} \\
(0.446) \\
\end{array}$ & $\begin{array}{l}2.493^{*} \\
(0.644) \\
\end{array}$ & & \\
\hline InPORTS F2 & & & & & & & & & & $\begin{array}{l}0.042^{*} \\
(0.005)\end{array}$ & $\begin{array}{l}0.052^{*} \\
(0.014)\end{array}$ \\
\hline NX x Infra & & & & & $\begin{array}{l}0.203^{*} \\
(0.020)\end{array}$ & & $\begin{array}{l}-0.297^{*} \\
(0.092)\end{array}$ & & $\begin{array}{c}0.034 \\
(0.123)\end{array}$ & & $\begin{array}{l}0.090^{*} \\
(0.015)\end{array}$ \\
\hline $\begin{array}{l}\text { GINI x } \\
\text { Infra }\end{array}$ & & & & & & & & $\begin{array}{l}-4.199 * \\
(0.576)\end{array}$ & $\begin{array}{l}-3.423^{*} \\
(0.774)\end{array}$ & & \\
\hline ECM & $\begin{array}{l}-1.22^{*} \\
(0.12)\end{array}$ & $\begin{array}{l}-1.12^{*} \\
(0.12)\end{array}$ & $\begin{array}{l}-1.13^{*} \\
(0.12)\end{array}$ & $\begin{array}{l}-1.13^{*} \\
(0.12)\end{array}$ & $\begin{array}{l}-1.14^{*} \\
(0.13)\end{array}$ & $\begin{array}{l}-1.17^{*} \\
(0.11)\end{array}$ & $\begin{array}{l}-1.17^{*} \\
(0.12)\end{array}$ & $\begin{array}{l}-1.16^{*} \\
(0.15)\end{array}$ & $\begin{array}{l}-1.15^{*} \\
(0.12)\end{array}$ & $\begin{array}{c}-1.059^{*} \\
(0.16)\end{array}$ & $\begin{array}{l}-1.039 * \\
(0.221)\end{array}$ \\
\hline h-test & $\begin{array}{c}8.01 \\
{[0.16]}\end{array}$ & $\begin{array}{c}9.29 \\
{[0.10]}\end{array}$ & $\begin{array}{c}8.98 \\
{[0.11]}\end{array}$ & $\begin{array}{c}7.42 \\
{[0.19]}\end{array}$ & $\begin{array}{c}9.25 \\
{[0.16]} \\
\end{array}$ & $\begin{array}{l}27.38^{*} \\
{[0.00]} \\
\end{array}$ & $\begin{array}{l}10.52 \\
{[0.10]}\end{array}$ & $\begin{array}{l}12.05 \\
{[0.06]} \\
\end{array}$ & $\begin{array}{c}7.73 \\
{[0.36]} \\
\end{array}$ & $\begin{array}{c}2.32 \\
{[0.80]}\end{array}$ & $\begin{array}{c}9.89 \\
{[0.13]} \\
\end{array}$ \\
\hline RLL & 600.06 & 623.59 & 590.91 & 590.48 & 636.70 & 590.60 & 617.02 & 614.10 & 624.27 & 748.05 & 678.29 \\
\hline ULL & 826.00 & 933.61 & 853.92 & 829.56 & 970.63 & 894.62 & 1001.34 & 1010.54 & 1178.98 & 1570.71 & 1315.17 \\
\hline LR: $\chi^{2}$ & 451.89* & 620.04* & 526.01* & 478.17* & 667.86* & 608.05* & 768.63* & 792.88* & $1109.42 *$ & $1645.32 *$ & 1273.75* \\
\hline
\end{tabular}




\begin{tabular}{|c|c|c|c|c|c|c|c|c|}
\hline & $15 a$ & $15 b$ & 16 & $17 \mathrm{a}$ & $17 \mathrm{~b}$ & $18 \mathrm{a}$ & $18 \mathrm{~b}$ & 19 \\
\hline ARDL: & $3,3,2,1,3$ & $3,3,3,1,3,1$ & $3,3,2,1,3$ & $\mathbf{3 , 3}, \mathbf{3 , 3}, \mathbf{3}$ & $3,3,1,1,1,1$ & $3,3,3,3,3$ & $3,3,1,2,2,3$ & $3,3,2,1,3$ \\
\hline $\ln (\mathrm{R} \& \mathrm{D} / \mathrm{Y} / \mathrm{L})$ & $\begin{array}{l}0.052 * \\
(0.013) \\
\end{array}$ & $\begin{array}{l}0.106^{*} \\
(0.016) \\
\end{array}$ & $\begin{array}{l}0.028 * \\
(0.015) \\
\end{array}$ & $\begin{array}{l}0.024^{*} \\
(0.010)\end{array}$ & $\begin{array}{l}0.031^{*} \\
(0.012)\end{array}$ & $\begin{array}{l}0.039 * \\
(0.010)\end{array}$ & $\begin{array}{l}0.031^{*} \\
(0.007) \\
\end{array}$ & $\begin{array}{l}0.053 * \\
(0.013) \\
\end{array}$ \\
\hline SKRAT & $\begin{array}{l}-0.045^{*} \\
(0.016)\end{array}$ & $\begin{array}{c}-0.067 * \\
(0.015) \\
\end{array}$ & $\begin{array}{c}-0.057 \\
(0.014)\end{array}$ & $\begin{array}{c}-0.024 \\
(0.019)\end{array}$ & $\begin{array}{c}-0.045^{*} \\
(0.021)\end{array}$ & $\begin{array}{l}-0.026^{*} \\
(0.020)\end{array}$ & $\begin{array}{c}-0.029 * \\
(0.014)\end{array}$ & $\begin{array}{c}-0.045^{*} \\
(0.016)\end{array}$ \\
\hline NX & $\begin{array}{l}0.041^{*} \\
(0.019)\end{array}$ & $\begin{array}{c}-9.713^{*} \\
(1.705)\end{array}$ & $\begin{array}{c}0.081 \\
(0.051)\end{array}$ & $\begin{array}{c}-0.086^{*} \\
(0.020)\end{array}$ & $\begin{array}{l}1.519 * \\
(0.599)\end{array}$ & $\begin{array}{c}-0.120^{*} \\
(0.022)\end{array}$ & $\begin{array}{l}4.139 * \\
(0.278)\end{array}$ & $\begin{array}{l}0.048 * \\
(0.021)\end{array}$ \\
\hline GINI & $\begin{array}{c}-0.340^{*} \\
(0.136)\end{array}$ & $\begin{array}{c}-0.355^{*} \\
(0.120)\end{array}$ & $\begin{array}{c}-0.499 * \\
(0.136)\end{array}$ & $\begin{array}{c}-0.305^{*} \\
(0.099)\end{array}$ & $\begin{array}{c}0.113 \\
(0.102)\end{array}$ & $\begin{array}{c}-0.538^{*} \\
(0.098)\end{array}$ & $\begin{array}{c}0.122^{*} \\
(0.046)\end{array}$ & $\begin{array}{c}-0.341^{*} \\
(0.128)\end{array}$ \\
\hline $\operatorname{lnSAA~F2}$ & $\begin{array}{c}0.007 \\
(0.026)\end{array}$ & $\begin{array}{c}0.405^{*} \\
(0.071)\end{array}$ & & & & & & \\
\hline $\operatorname{lnAPASS~F2}$ & & & $\begin{array}{l}0.036 * \\
(0.007)\end{array}$ & & & & & \\
\hline lnELEC F2 & & & & $\begin{array}{c}0.040^{*} \\
(0.014) \\
\end{array}$ & $\begin{array}{c}-0.175^{*} \\
(0.033) \\
\end{array}$ & & & \\
\hline lnFTEL F2 & & & & & & $\begin{array}{c}0.072 * \\
(0.013) \\
\end{array}$ & $\begin{array}{c}-0.244^{*} \\
(0.016) \\
\end{array}$ & \\
\hline lnTEL F1 & & & & & & & & $\begin{array}{c}0.019 \\
(0.026)\end{array}$ \\
\hline NX x Infra & & $\begin{array}{l}0.632 * \\
(0.110) \\
\end{array}$ & & & $\begin{array}{c}-0.113^{*} \\
(0.047) \\
\end{array}$ & & $\begin{array}{c}-0.252^{*} \\
(0.017) \\
\end{array}$ & \\
\hline ECM & $\begin{array}{c}-1.12 * \\
(0.13) \\
\end{array}$ & $\begin{array}{c}-0.951^{*} \\
(0.171) \\
\end{array}$ & $\begin{array}{l}-1.13^{*} \\
(0.11) \\
\end{array}$ & $\begin{array}{l}-1.09 * \\
(0.14) \\
\end{array}$ & $\begin{array}{c}-1.146^{*} \\
(0.102) \\
\end{array}$ & $\begin{array}{l}-1.01^{*} \\
(0.14) \\
\end{array}$ & $\begin{array}{c}-1.413^{*} \\
(0.261)\end{array}$ & $\begin{array}{l}-1.12 * \\
(0.13)\end{array}$ \\
\hline h-test & $\begin{array}{c}8.48 \\
{[0.13]} \\
\end{array}$ & $\begin{array}{c}6.73 \\
{[0.35]} \\
\end{array}$ & $\begin{array}{c}3.13 \\
{[0.68]}\end{array}$ & $\begin{array}{c}10.26 \\
{[0.07]}\end{array}$ & $\begin{array}{c}6.89 \\
{[0.33]}\end{array}$ & $\begin{array}{c}28.78^{*} \\
{[0.00]}\end{array}$ & $\begin{array}{c}6.91 \\
{[0.33]}\end{array}$ & $\begin{array}{c}11.02 \\
{[0.05]}\end{array}$ \\
\hline RLL & 588.63 & 656.34 & 595.31 & 735.98 & 545.83 & 743.69 & 694.25 & 588.81 \\
\hline ULL & 873.45 & 1451.78 & 846.20 & 1341.23 & 759.79 & 1348.70 & 1456.74 & 871.36 \\
\hline LR: $\chi^{2}$ & 569.63* & 1590.89* & 501.79* & 1210.49* & $427.92 *$ & $1210.02 *$ & 1524.99* & $565.10^{*}$ \\
\hline
\end{tabular}

\begin{tabular}{cccccr}
\hline \multicolumn{3}{l}{ TABLE 10: Total Recommended Paved Roads Distance } \\
between South Africa's Four Major Metropolitan Centres \\
\hline 1970 & 1975 & 1980 & 1985 & 1990 & 1995 \\
6480 & 6467 & 6444 & 6422 & 6401 & 6385 \\
\hline
\end{tabular}


Figure 1: Historical Evolution of Infrastructure in South Africa. Source: Fedderke, Perkins and Luiz (2005).
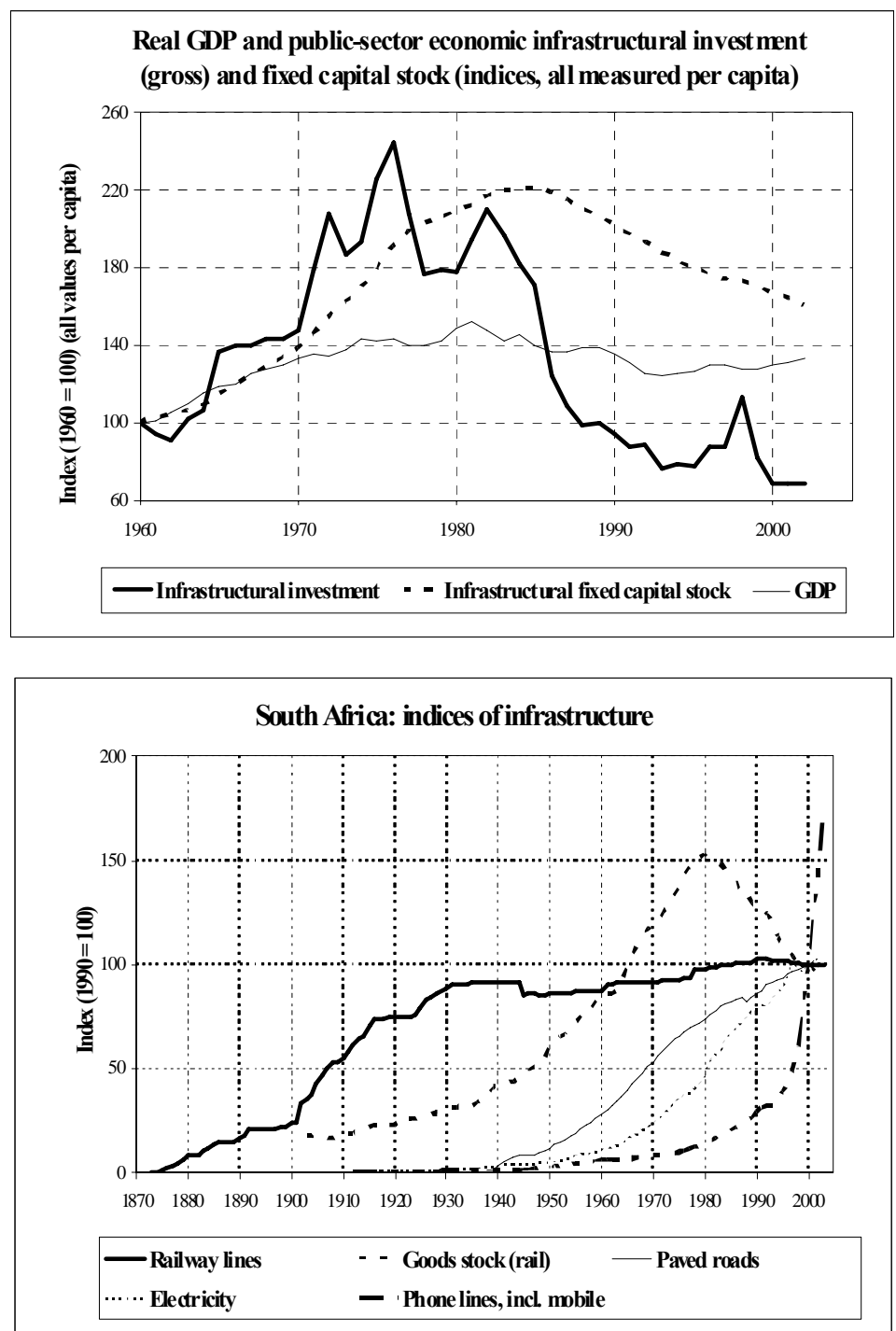
Figure 2: Results for Output per Worker

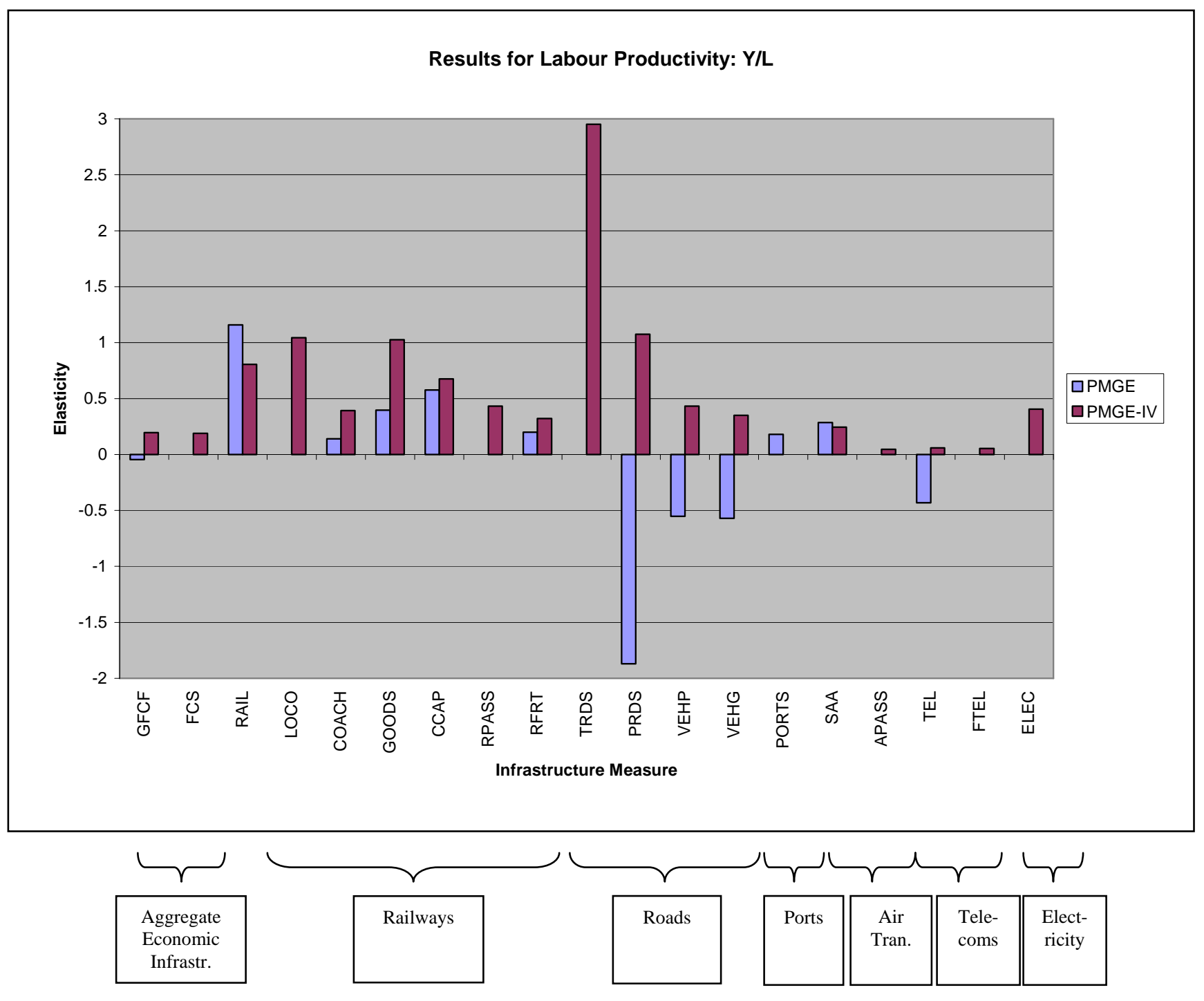


Figure 3: Net Impact of the Ports Measure and Net Exports in the Presence of Threshold Effects

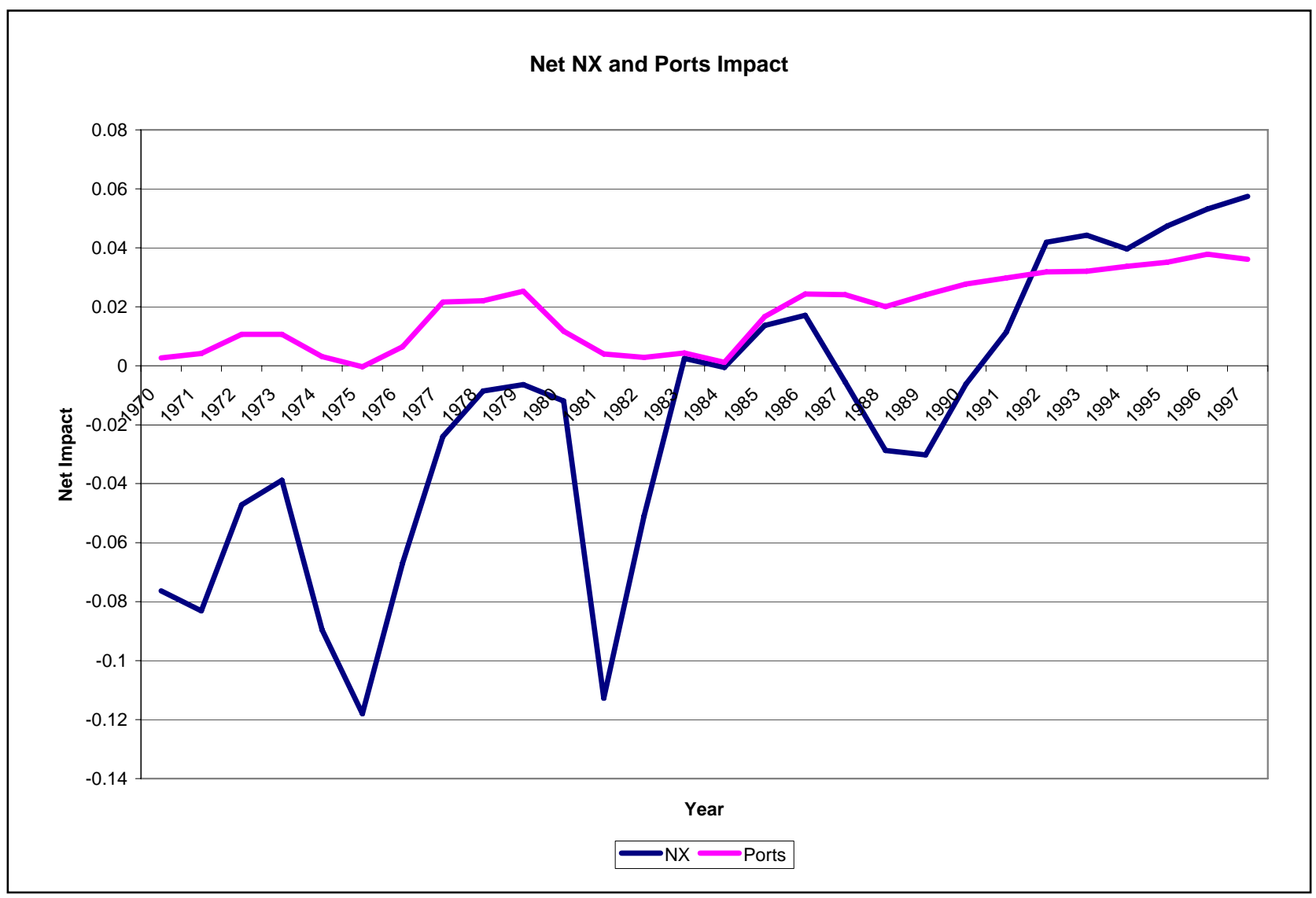


Figure 4: Net Impact of the Domestic Carrier Measure and Net Exports in the Presence of Threshold Effects

Net NX and SAA Impact

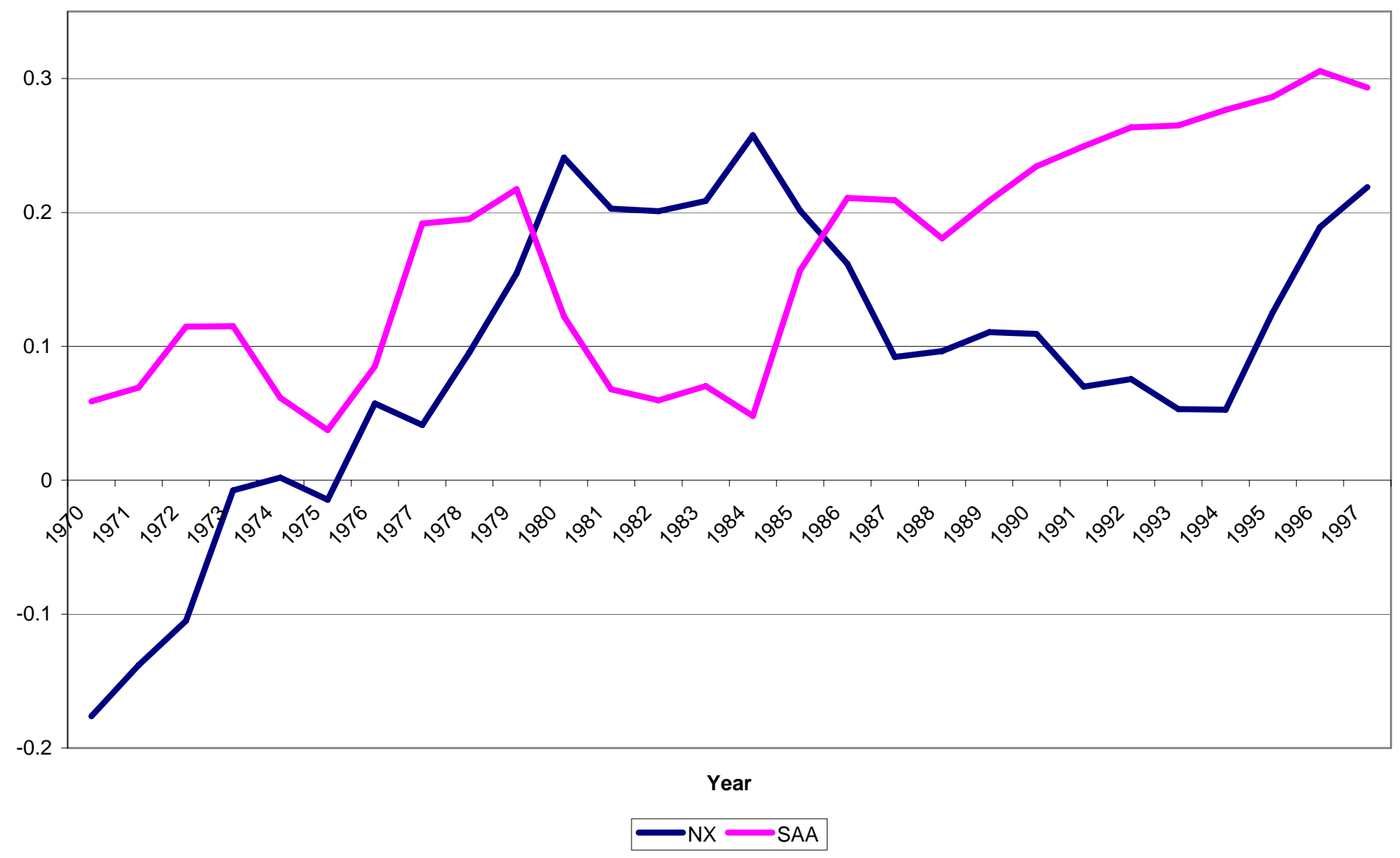


Figure 5: Results for TFP

TFP

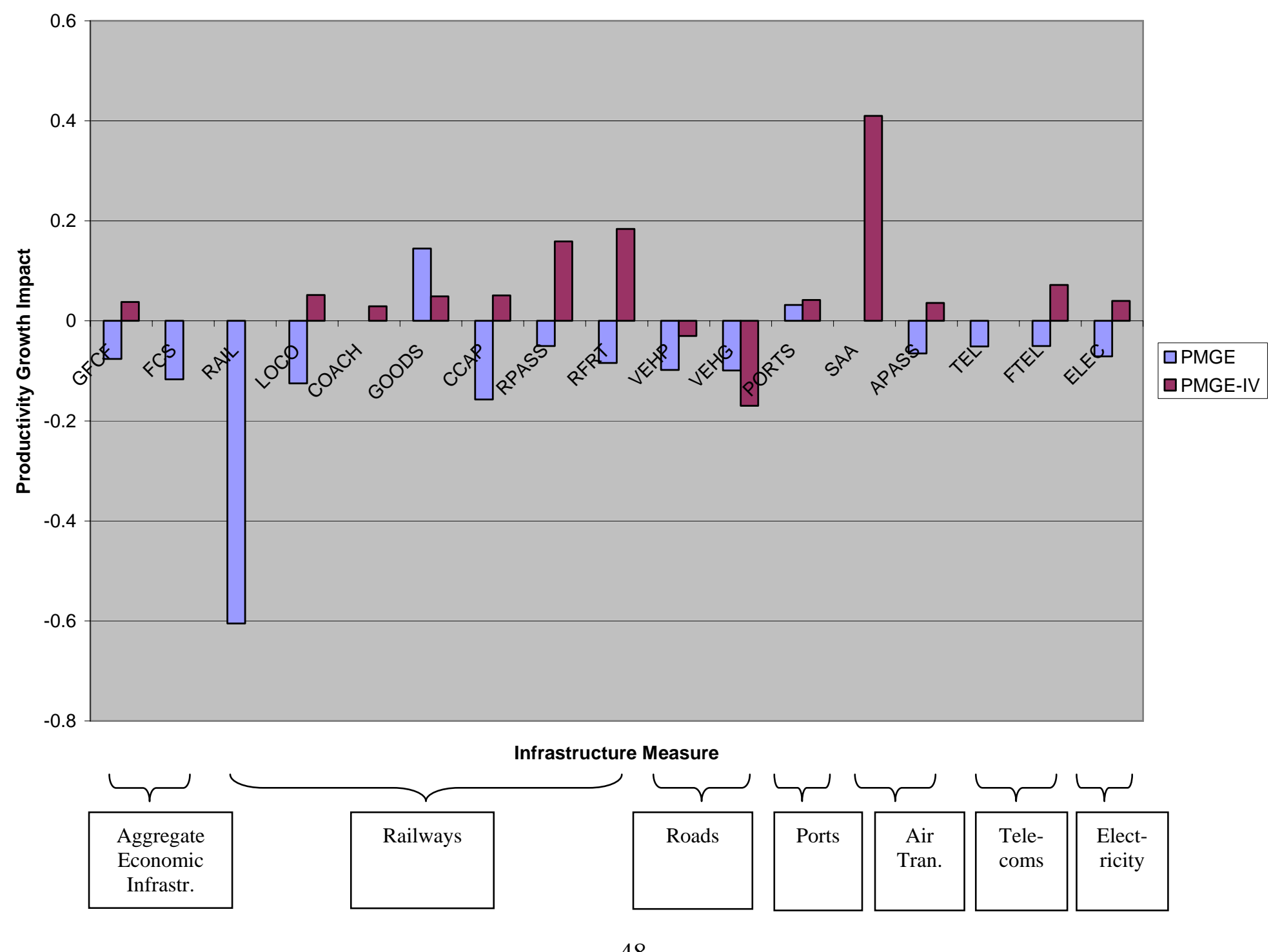

